Universidad Politécnica de Valencia

Escuela Técnica Superior de Ingenieros Agrónomos
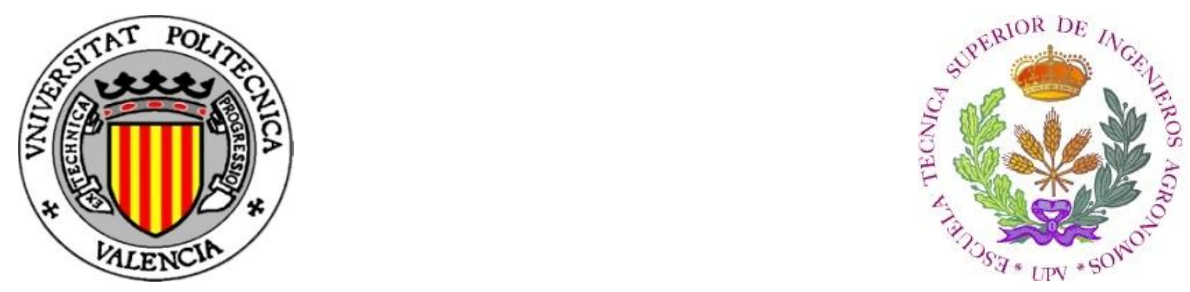

\title{
Regulated deficit irrigation in citrus: agronomic response and water stress indicators
}

\author{
Memoria presentada por \\ CARLOS BALLESTER LURBE \\ para optar al grado de \\ DOCTOR INGENIERO AGRÓNOMO \\ Directores \\ Dr. Juan Ramón Castel Sánchez y Dr. Diego S. Intrigliolo Molina
}

Valencia, marzo, 2013 

Tesis realizada bajo el programa FPI-INIA-CCAA 



\section{AGRADECIMIENTOS}

Como me imagino será el caso de la mayoría de personas que se deciden por obtener el título de doctor, la consecución de éste ha sido posible gracias a la ayuda, en muy distintas formas, de un número muy amplio de personas.

En primer lugar agradezco a mis directores de Tesis D. Juan Ramón Castel Sánchez y D. Diego Sebastiano Intrigliolo Molina el haberse preocupado de que mi formación como investigador haya sido la mejor posible. Agradezco los valiosos consejos que me han dado para, como mínimo, intentar avanzar en el mundo de la investigación teniendo en cuenta como de difícil se presenta el futuro próximo.

Agradezco a Bernardo Pascual España su ayuda prestada tanto en la redacción de la tesina de Máster como en el proceso de elaboración de la tesis.

Debo agradecer infinitamente a D. Pedro Ferrer Talón, por segunda vez desde mis estudios universitarios, sus recomendaciones, sin las cuales yo no hubiera podido recalar en el instituto valenciano de investigaciones agrarias y no hubiera tenido opción de conseguir la beca que me ha permitido realizar los estudios de doctorado. Tengo la impresión de que nunca podré agradecerte suficientemente tu esfuerzo y la ayuda que me has prestado en mi formación.

Agradezco enormemente el apoyo de Marta Serrano en la decisión de aventurarme en la realización del doctorado. 
Gracias a Javier Castel, mi compañero de campo durante todo este tiempo, por su ayuda, por lo que he aprendido gracias a él y por los almuerzos y buenos momentos que hemos pasado juntos.

Gracias a Luis Bonet, Miguel Ángel Jiménez Bello, a todos los compañeros de la unidad de riegos (Felipe Sanz, Diego Pérez, Antonio Yeves, David Risco, Laura Pérez, Ángela Martínez, Eduardo Badal, Diego Guerra, Josep , Ignacio Buesa y Carlos Albert) y a los compañeros del CEDAS (Carlos Ramos, José Miguel de Paz, Piedad, Paco, Aurelio y Amparo) por todos los buenos momentos pasados juntos. Todos ellos han conseguido que cuatro años me hayan pasado en un suspiro.

Me gustaría agradecer a Raquel Rosales la paciencia con la que ha llevado mis innumerables preguntas, a veces agobiantes, sobre diversos aspectos de la tesis.

Por último, gracias a mi familia por su apoyo y en especial a mi hermana Begoña, quien teniendo ya el título de doctora me ha sido de gran ayuda en muchos momentos del doctorado.

De corazón, gracias a todos. 
A mi abuela Felicidad 



\section{Resumen}

Previo a la recomendación de estrategias de riego deficitario controlado (RDC) en parcelas comerciales de cítricos es necesaria la realización de experimentos a nivel local. El éxito de una estrategia de RDC depende de la gestión que se haga del estrés hídrico, es decir, en qué periodo se aplica y qué grado de estrés alcanzan los árboles. Por ello, indicadores de estrés hídrico precisos y de fácil manejo son fundamentales cuando estrategias de RDC son llevadas a cabo. El presente trabajo está dividido en cinco experimentos realizados en Valencia, la principal área citrícola de España. Los objetivos generales fueron el estudio de la respuesta agronómica de la mandarina 'Clementina de Nules' y de la naranja 'Navel Lane Late' a dos estrategias de RDC aplicadas en verano y la evaluación para la detección de estrés hídrico de medidas de flujo de savia (FS), temperatura de la copa $\left(\mathrm{T}_{\mathrm{c}}\right)$ e indicadores derivados de éstos como alternativa a métodos más clásicos como el potencial hídrico de tallo $\left(\Psi_{\mathrm{s}}\right)$ y la conductancia estomática $\left(\mathrm{g}_{\mathrm{s}}\right)$. Algunos de estos indicadores de estrés hídrico se emplearon también en una plantación de caqui, cultivo menos sensible a cambios en el déficit de presión de vapor del aire (DPV) que los cítricos. Los resultados obtenidos en cítricos mostraron que reducciones del riego del 30-40\% de la evapotranspiración de cultivo $\left(\mathrm{ET}_{\mathrm{c}}\right)$ durante el verano redujeron la producción debido a un menor tamaño final del fruto en ambas especies. Sin embargo, el tratamiento moderado de estrés (RDI-1) regado al 50\% de la $\mathrm{ET}_{\mathrm{c}}$ permitió ahorros de agua del $20 \%$ en 'Clementina de Nules' con reducciones del crecimiento vegetativo pero sin reducciones significativas en producción o tamaño del fruto. 'Navel Lane Late' resultó ser más 
sensible al déficit hídrico e incluso el tratamiento de menor restricción, RDI1, redujo el tamaño final del fruto aunque permitió ahorros de agua del 19\% sin reducciones en la producción cuando la integral de estrés no sobrepasó el valor de $70 \mathrm{MPa}$ *ía en un periodo de 71 días. Los tratamientos RDC mejoraron la calidad interna de la fruta aumentando los sólidos solubles totales y la acidez en ambas especies de cítricos. En cuanto a los indicadores de estrés hídrico estudiados, los valores absolutos de FS infraestimaron la transpiración de los árboles. En promedio para el periodo de restricciones hídricas, una reducción del 50\% en el riego aplicado a los árboles bajo RDC en ambas especies redujo la transpiración en un $15 \%$ en comparación con árboles control. Tanto la ratio FS nocturno/diurno como la transpiración relativa estuvieron en consonancia con las diferencias observadas en $\Psi_{\mathrm{s} \text {. El }}$ uso de cámara termográfica en cítricos permitió detectar diferencias en $\mathrm{T}_{\mathrm{c}}$ entre árboles de distintos tratamientos de riego (de hasta $1.7^{\circ} \mathrm{C}$ ) cuando el DPV no superó los $2.7 \mathrm{kPa}$. El análisis de imágenes térmicas resultó más adecuado para la detección de estrés hídrico que la utilización de sensores de infrarrojo fijos. En conclusión, este trabajo muestra que la estrategia RDI-1 puede ser aplicada en caso de escasez de agua tanto en 'Navel Lane Late' como en 'Clementina de Nules', en la que dicha estrategia puede aplicarse incluso como herramienta para controlar el crecimiento vegetativo mejorando la calidad de los frutos y reduciendo costes asociados al manejo del cultivo. Las medidas de FS y $\mathrm{T}_{\mathrm{c}}$ permiten detectar estrés hídrico en cítricos, sin embargo, el FS debería utilizarse preferentemente en términos relativos mientras que $T_{c}$ resulta más adecuada en cultivos con una menor respuesta al DPV como es el caqui. 


\section{Resum}

Previ a la recomanació d'estratègies de reg deficitari controlat (RDC) en parcel•les comercials de cítrics és necessari la realització d'experiments a nivell local. L'èxit d'una estratègia de RDC depén de la gestió que es faça de l'estrés hídric, és a dir, en que període s'aplica i que grau d'estrés aconseguixen els arbres. Per això, indicadors d'estrés hídric precisos i de fàcil maneig són fonamentals quan estratègies de RDC són dutes a terme. El present treball està dividit en cinc experiments realitzats a València, la principal àrea citrícola d'Espanya. Els objectius generals van ser l'estudi de la resposta agronòmica de la mandarina Clementina de Nules i de la taronja Navel Lane Late a dos estratègies de RDC aplicades a l'estiu i l'avaluació per a la detecció d'estrés hídric de mesures de flux de savia (FS), temperatura de la coberta vegetal dels arbres $\left(\mathrm{T}_{\mathrm{c}}\right) \mathrm{i}$ indicadors derivats d'estos com alternativa a mètodes més clàssics, potencial hídric de tija $\left(\Psi_{\mathrm{s}}\right)$ i conductància estomática $\left(\mathrm{g}_{\mathrm{s}}\right)$, que no poden automatitzar-se. A més de en cítrics, alguns d'estos indicadors d'estrés hídric es van testar en caqui, cultiu menys sensible a canvis en el dèficit de pressió de vapor de l'aire (DPV). Els resultats obtinguts en cítrics van mostrar que reduccions del reg del 30-40\% de l'evapotranspiració de cultiu $\left(\mathrm{ET}_{\mathrm{c}}\right)$ durant l'estiu van reduir la producció degut a una menor grandària final del fruit en ambdós espècies. No obstant, el tractament moderat d'estrés (RDI-1) regat al $50 \% \mathrm{ET}_{\mathrm{c}}$ va permetre estalvis d'aigua del $20 \%$ en Clementina de Nules amb reduccions del creixement vegetatiu però sense reduccions significatives en la producció o grandària del fruit. Navel Lane Late va resultar ser més sensible al dèficit hídric i inclús el tractament RDI-1 va reduir la grandària final del fruit 
encara que va permetre estalvis d'aigua del $19 \%$ sense reduccions en la producció quan la integral d'estrés no va sobrepassar el valor de $70 \mathrm{MPa} *$ día en un període de 71 dies. Els tractaments RDC van millorar la qualitat interna de la fruita augmentant els sòlids solubles totals i l'acidesa en ambdós espècies de cítrics. En lo que concern als indicadors d'estrés hídric estudiats, els valors absoluts de FS infraestimaren la transpiració dels arbres. Com a mitjana per al període de restriccions hídriques, una reducció del $50 \%$ en el reg aplicat als arbres RDC en ambdós espècies va reduir la transpiració en un $15 \%$ en comparació amb arbres control. Tant la ràtio FS nocturne/diurne com la transpiració relativa van estar d'acord amb les diferències en $\Psi_{\mathrm{s}}$. L'ús de camera termográfica en cítrics va permetre detectar diferències en $T_{c}$ entre arbres de distints tractaments de reg (de fins a $1.7^{\circ} \mathrm{C}$ ) quan el DPV no va superar els $2.7 \mathrm{kPa}$. L'anàlisi d'imatges tèrmiques va resultar més adequat per a la detecció d'estrés hídric que la utilització de sensors d'infraroig fixos en els que el camp de visió és menor i un menor nombre de fulls participen en el càlcul de $\mathrm{T}_{\mathrm{c}}$. En conclusió, este treball mostra que l'estratègia RDI-1 pot ser aplicada en cas d'escassetat d'aigua tant en Clementina de Nules com en Navel Lane Late. En el cas de la varietat de mandarina, menys sensible a l'estrés hídric, esta estrategia pot aplicar-se inclús com a ferramenta per a controlar el creixement vegetatiu millorant la qualitat dels fruits i reduint costos associats al maneig del cultiu. Les mesures de FS i T $\mathrm{c}_{\mathrm{c}}$ permeten detectar estrés hídric en cítrics, no obstant, el FS hauria d'utilitzar-se preferentment en termes relatius mentres que $T_{c}$ resulta més adequada en cultius amb una menor resposta al DPV com és el caqui. 


\section{Abstract}

Local experiments are needed before recommending regulated deficit irrigation (RDI) strategies for growers to be applied in commercial situations. The success of an RDI strategy depends on the water stress management, i.e. the timing and severity of the water stress applied, so accurate and easy-to-use plant water stress indicators are needed when RDI strategies are carried out. This $\mathrm{PhD}$ thesis, divided in five experiments performed in Valencia, the main citrus producing area of Spain, aimed to study the agronomic response of the mandarin 'Clementina de Nules' and the orange "Navel Lane Late" to two summer RDI strategies, and to assess the usefulness for plant water stress detection of sap flow (SF), canopy temperature $\left(\mathrm{T}_{\mathrm{c}}\right)$ and other indicators derived from them, as alternatives to the classical methods (i.e. stem water potential, $\Psi_{\mathrm{s}}$ and stomatal conductance, $\mathrm{g}_{\mathrm{s}}$ ) that cannot be automated. In addition, some of these water stress indicators in citrus were compared with Persimmon, a crop less sensitive to changes in air vapor pressure deficit (VPD) than citrus. Results in citrus showed that water savings achieved in the most stressed treatment (RDI-2), irrigated at $30-40 \%$ of crop evapotranspiration $\left(\mathrm{ET}_{\mathrm{c}}\right)$ during summer, impaired yield by reducing fruit size in both orange and mandarin. However, the moderately stressed treatment (RDI-1) irrigated at $50 \% \mathrm{ET}_{\mathrm{c}}$, allowed for $20 \%$ water savings in 'Clementina de Nules' with a reduction in tree growth but without any significant reduction in yield or fruit size. 'Navel Lane Late' resulted to be more sensitive to water deficit since even the RDI-1 strategy reduced fruit size in this cultivar. However, this RDI strategy allowed water savings of up to $19 \%$ without reduction in yield in 
years when the water stress integral did not surpass $70 \mathrm{MPa}$ day during a period of 71 days. RDI improved fruit quality increasing total soluble solids and titratable acidity in both citrus species. Regarding the plant water stress indicators, absolute SF values underestimated the tree water use. Averaged over the entire period of water restrictions, a reduction of about $50 \%$ in water application in the RDI trees of both citrus species decreased tree transpiration compared to the control trees by only a 15\%. Both, the nocturnal-to-diurnal SF ratio and the relative transpiration ratio were in good agreement with differences in $\Psi_{\mathrm{s}}$. The use of a thermographic camera in citrus allowed detecting differences in $\mathrm{T}_{\mathrm{c}}$ between control and waterstressed trees (up to $1.7^{\circ} \mathrm{C}$ ) only when VPD values were below $2.7 \mathrm{kPa}$. Thermal imaging was more useful to detect plant water stress in citrus than the use of fixed infrared thermometer sensors in which the field of view is lower and therefore $T_{c}$ is obtained from fewer leaves. In conclusion this work shows that the RDI-1 strategy can be applied in case of water scarcity in commercial groves of the two citrus species here studied, but also in 'Clementina de Nules' as a tool to control vegetative growth improving fruit composition and reducing costs associated with the crop management. SF sensors and $T_{c}$ measurements are useful for detecting plant water stress. However, SF measurements should be preferentially used in relative terms while the use of $T_{c}$ measurements seems to be more precise in crops with a low response to VPD like Persimmon. 


\section{INDEX}

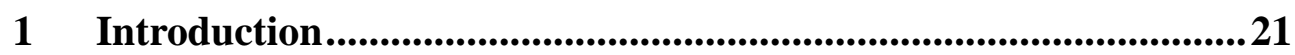

1.1 Citrus: general aspects and main species cultivated in Spain .........22

1.2 Citrus trade and world markets ............................................. 25

1.3 Producing regions in Spain ............................................ 27

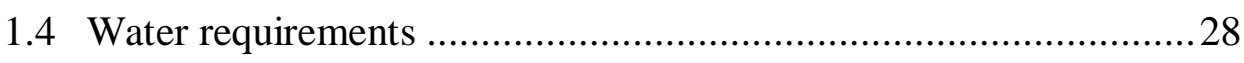

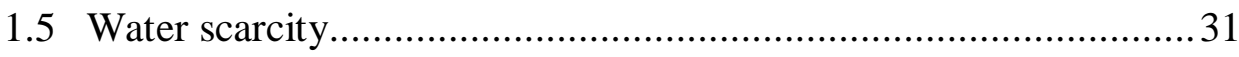

1.6 Regulated deficit irrigation ............................................. 32

1.6.1 Crop critical periods.................................................... 33

1.6.2 Effects of deficit irrigation on tree performance ................... 35

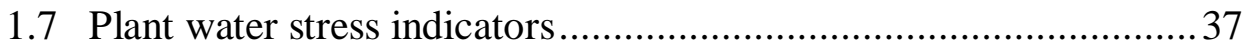

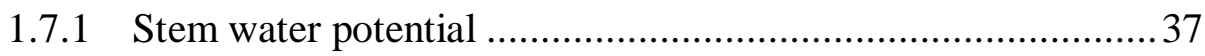

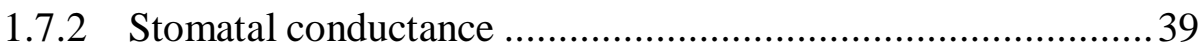

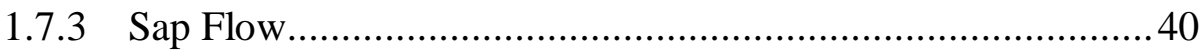

1.7.4 Canopy temperature ..................................................... 43

1.8 Objectives ................................................................. 45

2 Materials and methods............................................................48 
2.1 Experiment 1: Summer RDI strategies in 'Clementina de Nules' citrus trees

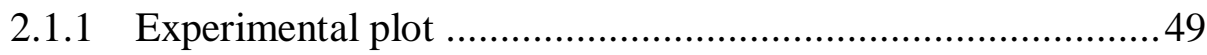

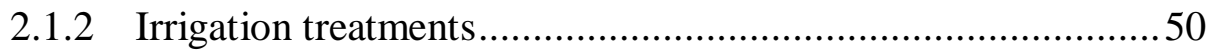

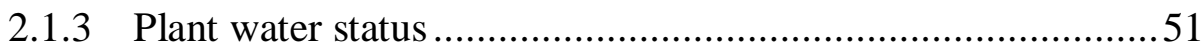

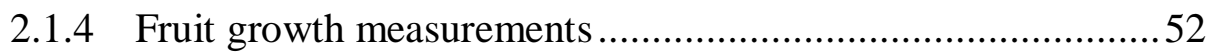

2.1.5 Yield determinations ....................................................... 53

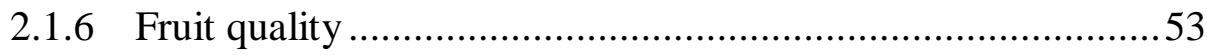

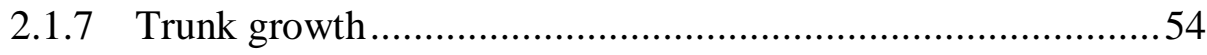

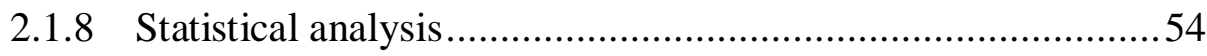

2.2 Experiment 2: Summer RDI strategies in 'Navel Lane Late' citrus

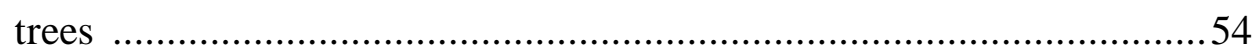

2.2.1 Experimental plot and irrigation treatments .........................54

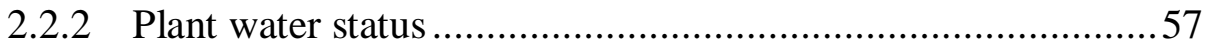

2.2.3 Trunk growth, yield and fruit quality...............................58

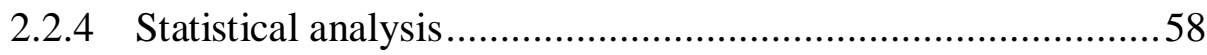

2.3 Comparison between 'Clementina de Nules' and 'Navel Lane Late' sensitivity to deficit irrigation .................................................5

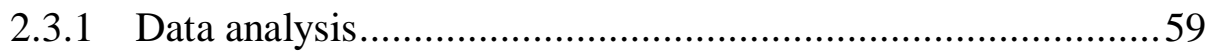


2.4 Experiment 3: Usefulness of sap flow measurements as a continuous plant water stress indicator of citrus trees .59

2.4.1 Experimental plots and treatments...................................59

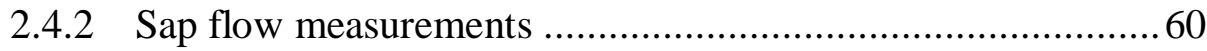

2.4.3 Plant water status determinations .........................................64

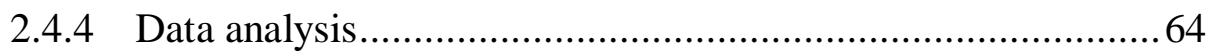

2.5 Experiment 4: Usefulness of thermography for plant water stress detection in citrus and persimmon trees ........................................6 65

2.5.1 Plot characteristics and irrigation treatments .......................65

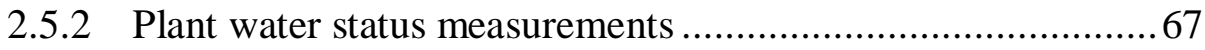

2.5.3 Image acquisition and processing .....................................6 67

2.5.4 Data analysis............................................................ 71

2.6 Experiment 5: Comparison of different plant water stress indicators

for citrus trees ....................................................................... 71

2.6.1 Experimental plot and irrigation treatments ........................ 71

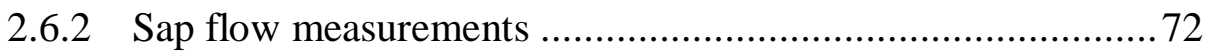

2.6.3 Canopy temperature measurements .................................... 73

2.6.4 Plant water status measurements ...................................... 75

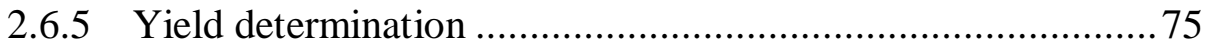




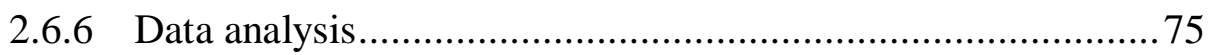

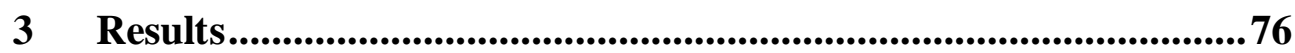

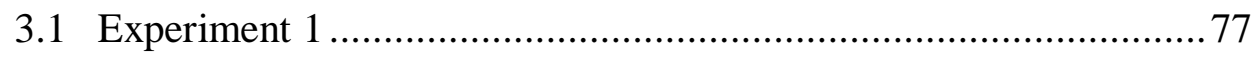

3.1.1 Meteorological conditions and irrigation volume applied ........77

3.1.2 Plant water status .............................................................

3.1.3 Yield and water use efficiency …………………................. 78

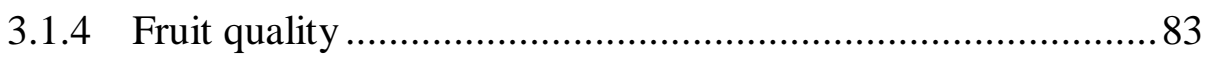

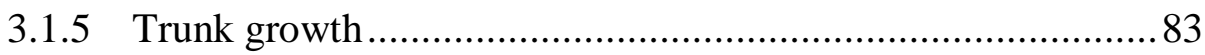

3.1.6 Economic return and water productivity................................... 85

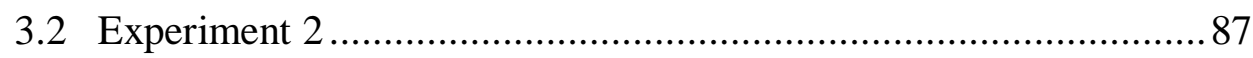

3.2.1 Meteorological conditions and irrigation volume applied ........87

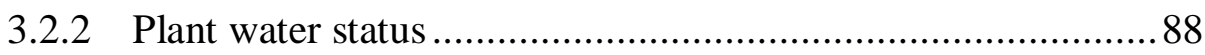

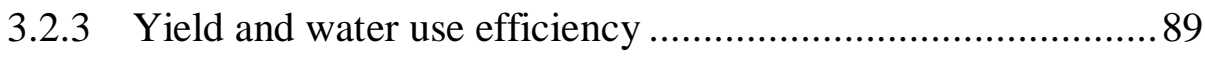

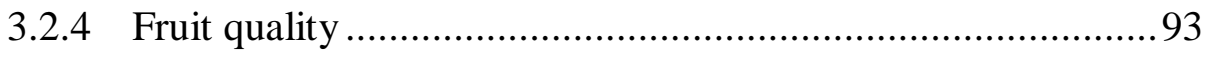

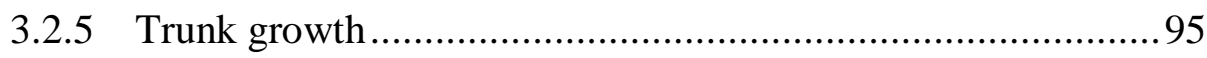

3.2.6 Economic return and water productivity .................................96

3.3 Comparison between 'Clementina de Nules' and 'Navel Lane Late'

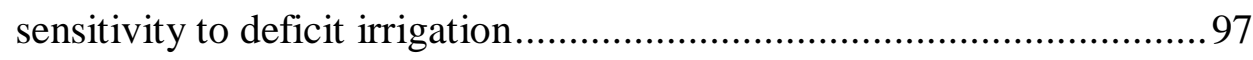

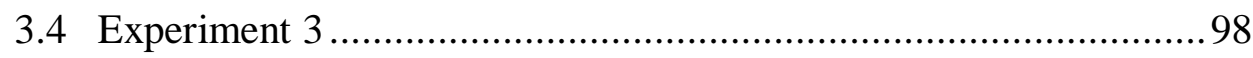


3.4.1 Meteorological conditions and plant water status .98

3.4.2 Sap flow measurements for plant transpiration estimations .. 101

3.4.3 Sap flow indices for plant water status estimations 105

3.5 Experiment 4 109

3.5.1 Meteorological conditions 109

3.5.2 Persimmon experiment 111

3.5.3 Citrus experiment 118

3.5.4 Sensitivity of the indicators 123

3.5.5 Assessment of intra-crown temperature variability for water stress detection 124

3.6 Experiment 5 126

\section{Discussion} 133

4.1 RDI strategies in commercial 'Clementina de Nules' and 'Navel

Lane Late' groves 134

4.2 Sap flow as plant water stress indicator 138

4.3 Thermal imaging for plant water stress detection in citrus and persimmon trees 144

4.3.1 Canopy temperature sensitivity to water stress in citrus and persimmon trees 
4.3.2 Comparison of different canopy temperature indexes 148

4.4 Performance of different water stress indicators for citrus trees... 150

5 Conclusions. 157

References 161 
1 Introduction 


\subsection{Citrus: general aspects and main species cultivated in Spain}

According to Swingle's botanic classification (Swingle, 1967), the cultivated citrus belong to the order Rutales, family Rutaceae, subfamily Aurantioideae, tribe Citreae, subtribe Citrinae and genera Citrus, Fortunella and Poncirus. Within these genera, the species from the genus Fortunella (kumquat) are short trees and shrubs that produce small fruit with oval or round shape. The genus Poncirus only has one species, $P$. trifoliata (L.), which is employed as a rootstock and has the peculiarity of being the only deciduous species among these three genera. The species from the genus Citrus, however, are the most important commercially since they are cultivated for their fruit, rich in vitamin $\mathrm{C}$ and citric acid, with a great value in markets both for fresh fruit and for juice production. According to Swingle and Reece (1967), the genus Citrus includes 16 species. The most cultivated species in Spain are $C$. sinensis (oranges); $C$. reticulata Blanco (mandarins); C. paradisi (grapefruit); C. limon (lemon); C. latifolia (Tahití lime) and C. aurantifolia (Mexican lime).

Citrus originally comes from south-eastern Asian countries, from Himalaya to the southern China, Indochina, Thailand, Malaysia and Indonesia, tropical regions where climate is hot and humid. Presently, they have been adapted to cooler and drier climates and citrus plantations can be found in the most part of tropical and subtropical regions between the $44^{\circ} \mathrm{N}$ and $41^{\circ} \mathrm{S}$ parallels (Agustí, 2003a). However, due to the suitable climate conditions for citrus growing, citrus production areas are mainly located in 
subtropical regions between the $20^{\circ} \mathrm{N}$ and $20^{\circ} \mathrm{S}$. The cultivation in other areas is limited mainly by the risk of freezing.

In Spain, the first reference to the presence of citrus is for the citron and dates to the seventh century. Four centuries later the Arabs introduced the sour orange, the lemon and the pummelo. It is not until late fifteenth century when it appears the first reference to the sweet orange, which probably was introduced in Spain through its trade relations with Italy and Portugal. Citrus were mainly used as ornamental plants until the end of the eighteen century when the widespread cultivation of this crop took place.

The root system of cultivated citrus trees is characterized by a taproot with an integrated network of woody lateral roots from which bunches of fibrous roots arise. These fibrous roots are the main responsible for uptaking water and nutrients from soil. In commercial groves citrus trees generally have one main trunk of round section divided in three or more ramifications, which confer the particular canopy shape to each tree. This canopy shape can be more or less spherical depending on the variety or even the pruning practice of each area. Citrus trees have a large number of leaves which differ in size depending on the species. Although citrus varieties are evergreen, continual leaf replacement occurs as trees grow. Leaves in citrus are unifoliate, have reticulate veins and have the vast majority of the stomata in the abaxial side of the leaf. The flowers are solitary or in small corymbs, with or without leaves. They are characterized by having five green sepals, five white petals, 20 - 40 stamens and eight to ten jointed carpels (Agustí, 2003b). The fruit is a hesperidium, a modified berry globose (oranges) to elongated (lemons) composed of a simple ovary 
covered by a tough, leathery peel. Peel color varies from yellow-green (lemon, lime, grapefruit) to orange with different intensities of red (orange and mandarins). The outermost layer of the peel has a large number of oil vesicles which confer the characteristic fragrance on citrus fruit. Just below the peel, the mesocarp called pith is white and spongy. The pulp, however, is composed of juice vesicles jointed by a string-like "hairs" to the segments, which provide fruit with nutrients and allow this to develop. Citrus fruit have a single sigmoid growth curve that can be divided in three stages (Figure 1).

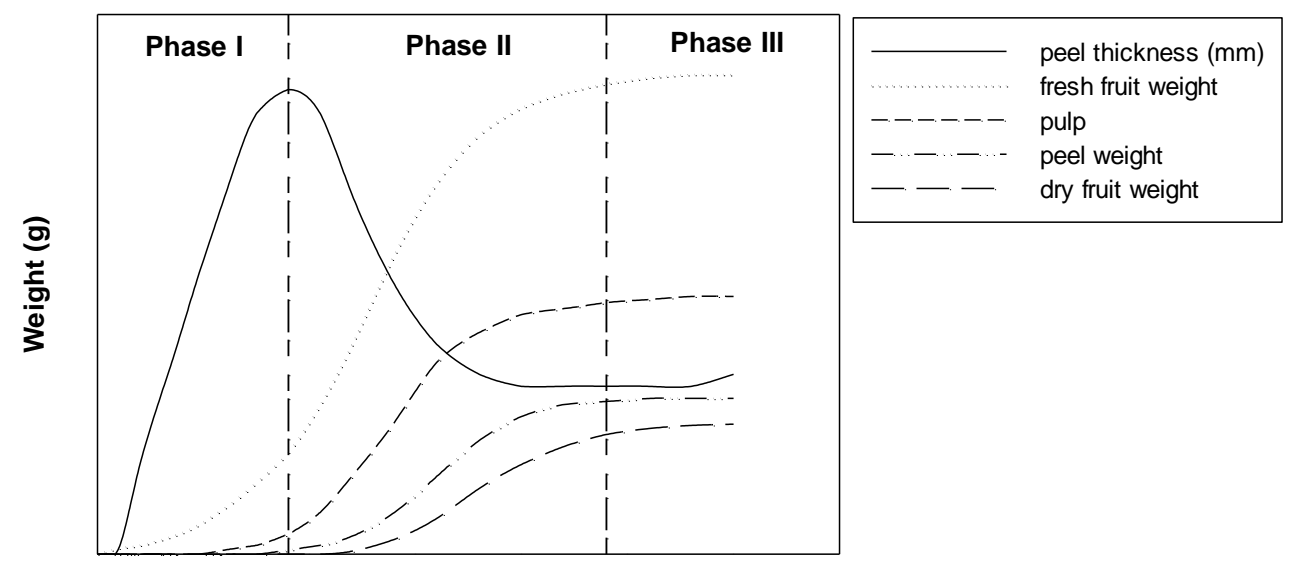

Time

Figure 1 Growth phases of a citrus fruit. Adapted from Agustí et al. (2003c).

The first stage is a period of slow volume growth but of intense cell division through all tissues. In this stage most of the fruit growth is due to the peel. Stage two is characterized by the cell enlargement and 
differentiation causing a fast fruit growth. In this stage, the increase in fruit size is due mainly to growth of the pulp segments. The stage three of fruit development is the maturation period, in which the growth is considerably lower than in the previous one. Fruit keep accumulating sugars and water while concentration of organic acids decreases.

\subsection{Citrus trade and world markets}

Citrus is one of the most important woody perennial crops worldwide with an annual production of nearly 122.5 million tons (FAOSTAT, 2010), more than a half being oranges. With more than 279.800 ha cultivated and an annual production of almost 5.3 million tons (MARM, 2010) Spain ranks first among the European Union (EU) citrus producers and sixth at world level. China, Brazil and USA are the main citrus producers in the world, followed by India and Mexico. However, these countries destine the majority of their production to domestic trade or to juice production, while Spanish citrus production is mainly oriented to exportation of fresh fruit being presently the main citrus exporter in the world (FAO, 2010).

With a production of 3.120 .000 tons of oranges in 2010, Spain ranked sixth among the world orange producers (Table 1). Navelina is the most important orange variety cultivated in Spain. In 2009, it had a production of 886.532 tons, $17 \%$ of the total Spanish citrus production (MARM, 2010). Late Navel oranges like Navelate, 'Navel Lane Late' and others yielded more than 700.000 tons. Other sweet oranges like Valencia 
Introduction

Late or Salustiana only represented 9 and $4 \%$ of the total citrus production respectively.

Table 1 Ranking of orange producers in the world (FAO 2010)

\begin{tabular}{ccc}
\hline Ranking & Area & Production (tons) \\
1 & Brazil & 18.101 .700 \\
2 & USA & 7.477 .920 \\
3 & India & 5.966 .400 \\
4 & China & 5.003 .289 \\
5 & Mexico & 4.051 .630 \\
6 & Spain & 3.120 .000 \\
\hline
\end{tabular}

Regarding mandarins, Spain ranks second among the citrus world producers being China by far the country with the highest productions in the world (Table 2).

In Spain there are about 105.000 ha planted with mandarins (MARM, 2010), 73\% of which are Clementine with an annual production of nearly 1.330.600 tons, mainly Clemenules and early maturing cultivars such as Marisol, Oronules and Oroval (Wardowski et al., 2006). Among the hybrid varieties Nova and Fortune stand out from other mandarins. Satsuma represents only the $8 \%$ of the total mandarin production. 
Lemon production in Spain relies mainly on the varieties Fino and Verna with an annual production of 558.180 tons. Grapefruit and other citrus species do not mean the $1 \%$ of the total citrus production.

Table 2 Ranking of mandarin producers in the world (FAO 2010)

\begin{tabular}{ccc}
\hline Ranking & Area & Production (tons) \\
1 & China & 10.142 .430 \\
2 & Spain & 1.708 .200 \\
3 & Brazil & 1.122 .730 \\
4 & Turkey & 858.699 \\
5 & Egypt & 796.867 \\
6 & Japan & 786.000 \\
\hline
\end{tabular}

\subsection{Producing regions in Spain}

The main citrus production areas in Spain are concentrated in the Mediterranean basin in the regions of Andalusia (Seville and Huelva), Murcia, Valencian Community (Alicante, Valencia and Castellón) and, to a lesser extent, Catalonia (Tarragona). In these regions the climate is Mediterranean warm with variable annual precipitations between 250 and $650 \mathrm{~mm}$ year $^{-1}$ and therefore irrigation is needed. The cultivation in other areas of the country is limited by cold injury risk. 
Most of the sweet oranges and mandarins are produced in the provinces of Valencia and Castellón, whilst lemon cultivation is more common in the areas of Alicante and, above all, in Murcia.

Among the regions mentioned the Valencian Community is the most important citrus producer in Spain with a contribution in 2010, according to the "Instituto Valenciano de Estadística (IVE)", of 3.508 .982 tons (49\% mandarins, $46 \%$ oranges and 5\% lemons). It means near the $64 \%$ of the total citrus production of Spain.

More than half of the total production of citrus in this region is destined to export as fresh fruit, mandarins above all, what situates the Valencian Community as the first exporting region in Spain. Germany, France and England are the main destinies of the Spanish citrus fruit (Instituto Valenciano de la exportación, IVEX). However, other countries like Holland, Poland and Belgium also import citrus fruit from Spain.

\subsection{Water requirements}

Estimates of citrus crop water requirements $\left(\mathrm{ET}_{\mathrm{c}}\right)$ can be obtained by multiplying the reference evapotranspiration $\left(\mathrm{ET}_{\mathrm{o}}\right)$ by a crop coefficient $\left(\mathrm{K}_{\mathrm{c}}\right)$ as follows (Doorenbos and Pruitt, 1977):

$$
E T_{c}=E T_{o} x K_{c}
$$

In this equation, $\mathrm{ET}_{\mathrm{o}}$ is the reference evapotranspiration defined as the rate that an extensive surface of green, well-watered grass of uniform height, actively growing and completely shading the ground evaporates water $(\mathrm{FAO}) . \mathrm{ET}_{\mathrm{o}}$ is climate dependent and can be determined by different 
methods from meteorological data, being the FAO-Penman-Monteith (Allen et al., 1998) the method most commonly employed. $K_{c}$ is the crop coefficient or the ratio between $\mathrm{ET}_{\mathrm{c}}$ and $\mathrm{ET}_{\mathrm{o}}$ and varies predominantly with the specific crop characteristics: kind of crop, phenological stage, tree size and agronomical practices including soil evaporation.

Many studies performed for determining citrus water requirements report a single annual $\mathrm{K}_{\mathrm{c}}$ value (Grieve, 1989; Grismer, 2000). Other studies, however, have shown that $\mathrm{K}_{\mathrm{c}}$ is not constant through the season. In Valencia, Castel $(1987,1997)$ determined the monthly $K_{c}$ for surface irrigated mature orange orchards and for a drip-irrigated 'Clementina de Nules' tree placed in a precise weighing lysimeter. This work showed the $K_{c}$ seasonal evolution with minimum values in spring due to changes in leaf area produced by pruning, and maximum values in autumn as a consequence of phenology and soil evaporation produced by rainfall. The monthly $\mathrm{K}_{\mathrm{c}}$ values of several studies on citrus are summarized in table 3.

The different results found among these and other studies are attributed to differences in soil evaporation conditions and canopy ground cover fraction (GC) of trees, highlighting the need to separate measurements of transpiration and soil evaporation (Villalobos et al., 2009). Villalobos et al., (2009) suggested the use of transpiration models to calculate $K_{c}$ as a function of specific variables in order to reduce the need to repeat experiments under different conditions. In this sense, Castel (2000) found a good relation between $\mathrm{K}_{\mathrm{c}}$ and $\mathrm{GC}$, fitting a quadratic equation:

$$
K_{c}=0.0283+0.0203 G C-0.00016 G C^{2}
$$


Later, Villalobos et al. (2009), however, found a linear relationship between the citrus transpiration coefficient $\left(\mathrm{K}_{\mathrm{p}}\right)$ and $\mathrm{GC}$ (from less than 0.01 to almost 0.80) that can be used to estimate citrus transpiration as:

$$
T=K_{p} * E T o=0.65 * G C * E T o
$$

Table 3 Monthly crop coefficients $\left(K_{c}\right)$ for several mature orange cultivars from different locations.

\begin{tabular}{lccccc}
\hline Source & $\begin{array}{c}\text { Castel \& } \\
\text { Buj, 1989 }\end{array}$ & $\begin{array}{c}\text { Castel et } \\
\text { al., 1987 } \\
\text { Washington } \\
\text { Cultivar }\end{array}$ & $\begin{array}{c}\text { Van Bavel } \\
\text { et al., 1967 }\end{array}$ & $\begin{array}{c}\text { Hoffman et } \\
\text { al., 1982 }\end{array}$ & $\begin{array}{c}\text { García }- \\
\text { Petillo \& } \\
\text { Castel, 2007 }\end{array}$ \\
Location & $\begin{array}{c}\text { Valencia, } \\
\text { Spain }\end{array}$ & $\begin{array}{c}\text { Valencia, } \\
\text { Spain }\end{array}$ & $\begin{array}{c}\text { Navel } \\
\text { Tempe, AZ }\end{array}$ & Yuma, AZ & $\begin{array}{c}\text { Valencia } \\
\text { Kiyú, } \\
\text { Uruguay }\end{array}$ \\
January & 0.66 & 0.54 & 0.57 & 0.43 & 0.51 \\
February & 0.65 & 0.63 & 0.46 & 0.42 & 0.62 \\
March & 0.66 & 0.47 & 0.43 & 0.66 & 0.71 \\
April & 0.62 & 0.53 & 0.55 & 0.56 & 0.78 \\
May & 0.55 & 0.48 & 0.72 & 0.69 & 0.83 \\
June & 0.62 & 0.57 & 0.74 & 0.74 & 0.86 \\
July & 0.68 & 0.59 & 0.75 & 0.78 & 0.88 \\
August & 0.79 & 0.68 & 0.76 & 0.87 & 0.87 \\
September & 0.74 & 0.62 & 0.76 & 0.87 & 0.85 \\
October & 0.84 & 0.68 & 0.85 & 0.79 & 0.81 \\
November & 0.73 & 0.75 & 0.93 & 0.45 & 0.75 \\
December & 0.63 & 0.79 & 0.75 & 0.34 & 0.67 \\
Mean & 0.68 & 0.61 & 0.69 & 0.63 & 0.76 \\
\hline
\end{tabular}

Table adapted from Goldhamer et al., (2012) 


\subsection{Water scarcity}

Some studies predict an increase in world population for the next 50 years of two to three billion people (Molden et al., 2007). This sharp increase in population along with the urbanization, industry development and new human eating habits will cause an increase in water demand. This forecasts an important reduction in the water available for irrigation necessary to face up the increase in food demand worldwide and highlights the need to work on irrigation strategies that allow growers to save water with the minimum possible impact on yield.

Spain, with the lowest water resources per habitant (Garrido and Llamas, 2009) is the most arid country of the EU. Water use and distribution is then a major issue in Spain and often it is object of conflict among regions. Given that the Spanish agriculture uses nearly the $85 \%$ of the available water, it is obvious that efforts to improve water management both on and off farm, are of paramount importance.

In the Valencian Community, where the experiments of this $\mathrm{PhD}$ thesis were carried out, nearly $50 \%$ of the cultivable area and practically all the citrus orchards are irrigated (GVA-CAPAA). Irrigation systems have undergone a notable modernization during the last 15 years standing the percentage of drip irrigated orchards at $72 \%$, being the remaining $28 \%$ irrigated by surface irrigation. This change of irrigation system has contributed to increase the irrigation efficiency by reducing the water used in irrigation (Castel et al., 1989). Moreover, it has also allowed growers to 
reduce the amount of fertilizers employed since these can be applied in a fractional way through the irrigation system.

Nevertheless, in spite of the advantages shown by the drip irrigation system, studies to determine the irrigation efficiency of a typical Water Users Association in Valencia (Spain), where the main crop was citrus, have shown that there is an important inefficiency at the plot irrigation level (López-Pérez et al., in press). These authors reported that $25 \%$ of the total plots studied (434) were deficit irrigated, while other 35\%, most of them young orchards where growers tried to save labor costs by placing the number of emitters needed in a mature orchard, received excess water. These results manifest that in spite of all the effort put into the hydraulic infrastructure in order to improve the efficiency of water distribution along the chain, from water reservoirs to the orchards, irrigation efficiency at the farm level can be greatly improved.

In this sense, it is relevant the study of irrigation strategies such as the regulated deficit irrigation (RDI), which may achieve substantial water savings. Crops under RDI are deliberately deficit irrigated during droughttolerant phenological stages while they are irrigated at full requirements during the rest of the season when plants are more sensitive to water stress.

\subsection{Regulated deficit irrigation}

This irrigation strategy was made explicit in the 1980's (Chalmers et al., 1981; Mitchell and Chalmers, 1982) in experiments performed in Australia on peach ( $c v$ Golden Queen) aimed to reduce the tree vegetative growth in high density orchards. These authors observed that water deficits 
applied specifically during the second stage of fruit growth (i.e. shell hardening), resulted in a significant reduction of vegetative growth while final fruit growth and yield were not impaired. Similar results were reported for pears some years later (Mitchell et al., 1989). Since then many studies have been conducted testing RDI strategies on the main fruit crops under different conditions and in different countries. Some of these studies reported contradictory results (Girona et al., 1993), highlighting the importance of the soil water retention capacity in the performance of RDI strategies, and the need of local experimentation for extrapolating results to other conditions.

From these studies it also became clear that the timing of RDI application in relation to the crop phenology is very important and therefore that it is essential to know which phenological stages are the droughttolerant for applying a water restriction and which ones are the critical periods when the crop should be well watered.

\subsubsection{Crop critical periods}

Flowering is generally considered a critical period for a large number of crops. Water restrictions during this phenological stage can inhibit ovule fertilization (Hsiao, 1993), reducing drastically the final number of fruit and consequently the yield. In citrus, even moderate water stress applied during phase I (i.e. flowering and fruit set) normally compromises yield by increasing June fruit drop (Doorenbos and Kassam, 1986; Ginestar and Castel, 1996; Romero et al., 2006; García-Tejero et al., 2010). 
Other phases of fruit growth are also considered as highly sensitive periods to deficit irrigation. Water deficit during last phase of citrus fruit growth and ripening is generally associated with a decrease in yield due to a fruit size reduction as well as an increase in fruit total soluble solids and acidity content (González-Altozano and Castel, 1999; Pérez-Pérez et al., 2009; García-Tejero et al., 2010). Water deficit during this phase in Navel oranges has been also associated with an increase in the affection of fruit peel creasing (Goldhamer and Salinas, 2000).

Generally in citrus the period after June fruit drop is the less sensitive to water stress and consequently the most appropriate period to apply water restrictions (González-Altozano and Castel, 1999). This is possible because despite the fact that fruit size is usually reduced by deficit irrigation, there is evidence that after a period of water restrictions, when irrigation is resumed to normal dose, fruit can grow faster than in normal conditions (Mitchell and Chalmers, 1982; Chalmers et al., 1986). In experiments with grapefruit in Israel (Cohen and Goell, 1988), and with 'Clemenules' in Valencia (González-Altozano and Castel, 2000), it was observed that deficit irrigation stopped fruit growth in volume although they continued accumulating dry matter. When water was resumed to normal dose a compensatory fruit growth occurred allowing fruit to grow faster than those from well-watered trees and therefore reaching a similar final size. Thus, when summer RDI strategies are applied it is important that water applications returns at full dosage sufficiently before harvest in order to allow for a possible compensation in fruit growth. 
Results in 'Clementina de Nules' in Valencia (González-Altozano and Castel, 1999) showed that moderate water restrictions (i.e. replacing only $50 \%$ of full $\mathrm{ET}_{\mathrm{c}}$ ) during July and August allowed reducing water application without neither yield nor fruit size reductions. Severe stress during summer, however, can reduce tree growth, final fruit size and increase juice total soluble solids.

\subsubsection{Effects of deficit irrigation on tree performance}

The main effect of deficit irrigation reported on fruit crops is a decrease in vegetative growth (Hilgeman, 1977; Levy et al., 1978), being the elongation of shoots and leaves the most affected (Hsiao, 1973, 1993; Day, 1981). This reduction in foliage growth has been considered as a plant adaptive mechanism to water stress since less foliage involve the interception of less radiation by the plant and consequently a reduction in water loss by transpiration (Hsiao et al., 1976). Similarly, the rolling up of the outer canopy leaves frequently observed in citrus trees under moderate to severe water stress conditions is another mechanism to limit solar radiation interception (Figure 2).

Branches and main trunk of deficit irrigated trees also reduce their growth leading to smaller canopy sizes, a fact that can be considered positive as it results in denser trees with a higher number of fruit per unit of canopy volume. Nevertheless, lemon trees can be subjected to a moderate water stress without manifesting any reduction in branches or trunk growth (Domingo, 1994). 

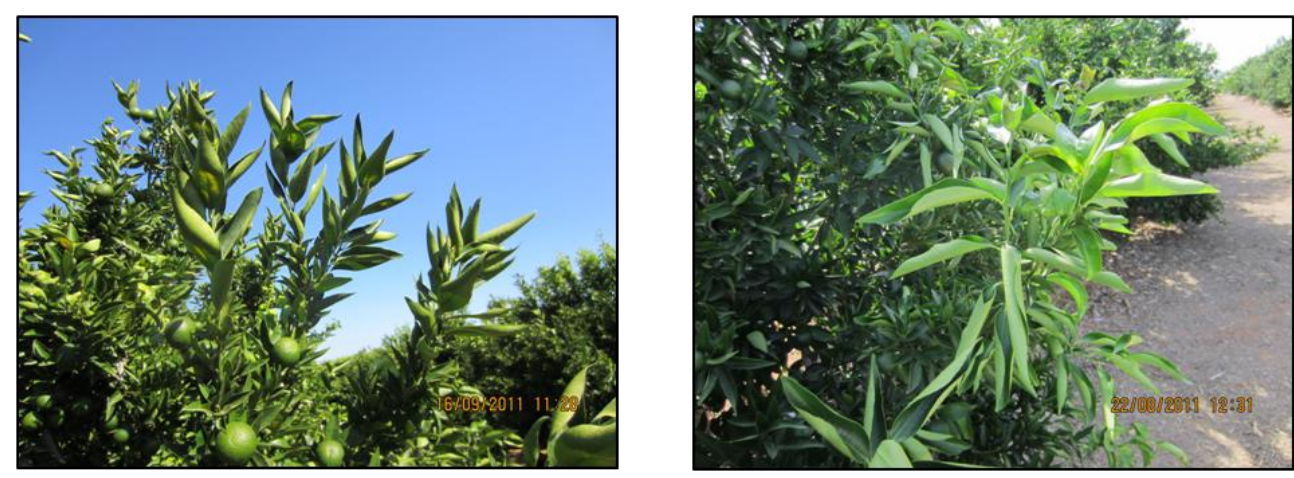

Figure 2 Rolling up effect on leaves from water-stressed citrus trees

Regarding the effects of deficit irrigation on roots, some studies have reported reductions in root growth as a consequence of low soil water availability (Landsberg and Jones, 1981; Bevington and Castle, 1985). However, this root growth reduction is normally lower than that in the aerial part of the plant (Kramer and Boyer, 1995), increasing the root to shoot ratio and ensuring then the water supply to the canopy (Syvertsen, 1985).

It is important to remark that crop response to a deficit irrigation is very dependent on the timing and severity of the water deficits applied (Fereres and Soriano, 2007). The key for a successful RDI application is to manage correctly the water stress: without precise and affordable water stress indicators, RDI may be a risky strategy. This is because plant response to a given reduction over the potential $\mathrm{ET}_{\mathrm{c}}$ might result in very different plant water stress levels according to several soil, environmental and tree endogenous factors. Surpassing a threshold value of plant water stress usually leads to a reduction in the final fruit size and the economic 
return. Therefore, when RDI strategies are applied, it is important to frequently check plant water status to avoid exceeding the tested threshold values for each species.

\subsection{Plant water stress indicators}

For the successful application of RDI strategies it is strongly recommended the use of plant based indicators of tree water status in order to check that trees reach the level of stress desired (Goldhamer et al., 2012). Stem water potential and stomatal conductance measurements are the most common methods employed to determine the plant water status in fruit tree crops. However, their measurements are labour-intensive and unsuitable for automation, characteristics that complicate the regular use of these methods for farmers or technicians in the field. Research now focuses on trying to find alternative methods that could overcome the limitations showed by the above mentioned 'classical' methods.

\subsubsection{Stem water potential}

The stem water potential $\left(\Psi_{\mathrm{s}}\right)$ measurement with a pressure chamber is the most common method employed to determine the plant water status in citrus trees (Figure 3). $\Psi_{\mathrm{s}}$ has been shown as more sensitive to water deficit than leaf water potential, and it is known as a precise plant water stress indicator in some fruit tree species because of its high sensitivity to the irrigation regime (Naor, 2000). It measures the potential energy with which water is retained in the xylem. Trees from soils with low humidity content will have lower $\Psi_{\mathrm{s}}$ than well-irrigated trees. Values above -1.0 MPa during a 
typical summer day of $\mathrm{ET}_{\mathrm{o}}$ about 6-7 $\mathrm{mm} \mathrm{d}^{-1}$ can be considered as values of trees in absence of water stress (Goldhamer et al., 2012). Values between 1.0 and $-1.5 \mathrm{MPa}$, however, are indicative of mild stress.

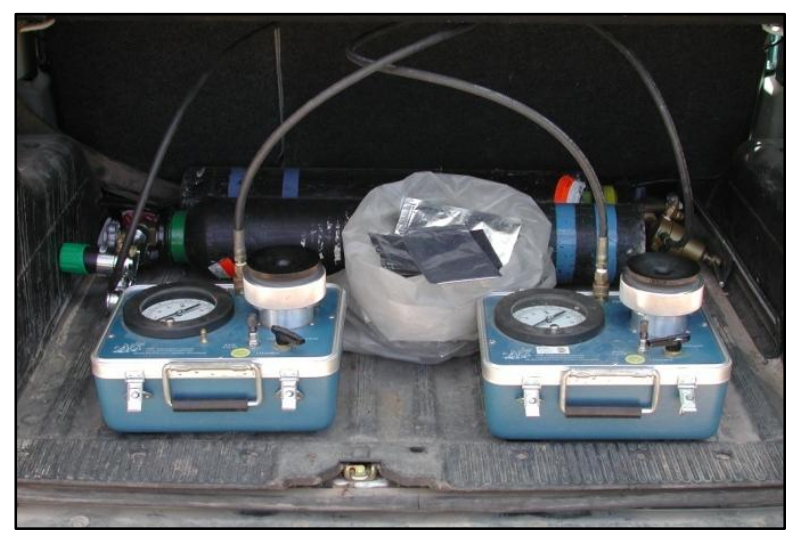

Figure 3 Cylinders and pressure chambers used for the stem water potential measurement.

In spite of being the most common method employed to determine plant water status in citrus, $\Psi_{\mathrm{s}}$ measurement shows some drawbacks. Apart from low water availability, $\Psi_{\mathrm{s}}$ can also be affected by environmental or endogenous factors (Jones, 1985). It shows temporal variability along the day and through the season regardless of plant water status. Furthermore, as mentioned in the previous section, $\Psi_{\mathrm{s}}$ measurement is laborious and cannot be automated. 


\subsubsection{Stomatal conductance}

Unlike $\Psi_{\mathrm{s}}$, the measurement of stomatal conductance $\left(\mathrm{g}_{\mathrm{s}}\right)$ shows the advantage that it is a non-destructive method so the same leaves of one specific tree can be measured several times. As $\Psi_{\mathrm{s}}, \mathrm{g}_{\mathrm{s}}$ is sensitive to low soil moisture so drought stressed trees will usually have lower $\mathrm{g}_{\mathrm{s}}$ values than trees in absence of water stress. Nevertheless, despite the fact that citrus are considered to be mesophyte plants, the leaves have some xeromorphic characteristics. The vast majority of the stomata of a citrus leaf are found in the abaxial leaf surface while the upper surface is covered by a thick waxy cuticle that suppresses cuticular transpiration (Kriedemann and Barrs, 1981). These characteristics make citrus leaves have lower $g_{s}$ values than other species like for instance, almond, persimmon or pistachio in the same soil water conditions.

Apart from soil moisture, $\mathrm{g}_{\mathrm{s}}$ depends on light intensity, temperature, air vapor pressure deficit (VPD), age of the leaf measured and so forth (Jones, 1983). As an example, experiments carried out in Ghana and Seville (Oguntunde et al., 2007; Villalobos et al., 2009) showed that in wellwatered orange trees VPD was the main regulator of transpiration and that citrus trees tend to reduce $g_{s}$ in response to high VPD. Contrarily, in other woody perennial crops such as persimmon trees there is some evidence that stomatal conductance might be more insensitive to VPD (Badal et al., 2010). 


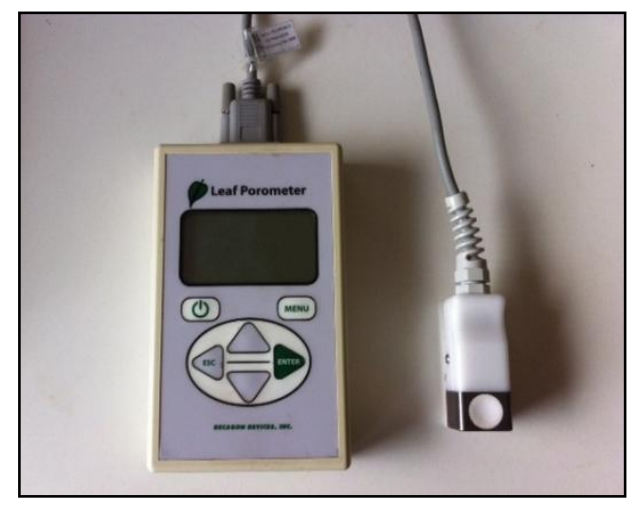

Figure 4 Porometer used for the stomatal conductance measurements.

\subsubsection{Sap Flow}

Although there are many methods of sap flow measurement based on different principles, the most commonly employed in the field are those based on using heat as a tracer of sap flow (Čermárk et al., 2004). Heatpulse methods have been used since decades ago (Huber, 1932). Huber was the first in using this method highlighting the importance of distinguishing between the effect of convection by sap flow and the transfer of heat by thermal conduction. He and Schmidt (1937), developed a system in which two temperature sensors were placed downstream and upstream of an external heater assuming that sap velocity was the same as that of the heatpulse. Later, Marshal (1958) showed that this assumption was not correct and proposed the use of a linear heater and temperature probes inserted radially into the trunk. Since then, new methods suitable for different experimental conditions have been developed: stem heat balance method 
(SHB); trunk sector heat balance method (THB); heat dissipation method (HD), heat field deformation method (HFD), T-max method; Green's heatpulse velocity method (HPV) and heat ratio method (HR). The fundamental of all these methods are described in detail in Fernández (2011).

In this work the methods employed for sap flow measurements were the HPV method (Green, 1988) and a variant of this, known as the calibrated average gradient method (CAG; Testi and Villalobos, 2009).

HPV method is based on the compensation heat-pulse (CHP) method (Marshall, 1958, Swanson and Whitfield, 1981). In this system two temperature probes inserted into the trunk are placed in either side of a linear heater that emits heat pulses of 1 to 2 seconds every certain period of time. The temperature probes equipped with thermocouples at different depths from the cambium are placed at different distances above and below the heater in order to compensate for the effects of thermal conduction. Heat-pulse velocity is obtained from the time spent in reaching both probes the same temperature. However, convection of the heat-pulse is perturbed by the insertion of the heater and temperature probes into the trunk, which causes a disruption of the xylem tissue. To avoid the underestimation of the heat-pulse velocity this must be corrected by applying a wounding factor. Once the velocity is corrected, sap flow density and volumetric sap flow can be obtained.

Despite the fact that CHP method provides good information for diurnal sap flow, it presents some constraints when measuring low sap velocities (Becker, 1998). The CAG method developed by Testi and 
Introduction

Villalobos (2009), however, allows calculating low sap velocities from sap flow measurements taken with the HPV method based on the linear relationship observed between heat-pulse velocity corrected for wounding effects and the average temperature difference measured over a given time.

Sap flow measurements can provide direct estimates of plant water flow and therefore can be used to study water relations in well-watered and drought stressed plants (Smith and Allen, 1996). Most of the RDI trials conducted on citrus have quantified water savings obtained on a base of the irrigation applications but not on actual estimation of tree transpiration. In citrus trees, RDI normally reduces stomatal conductance (García-Tejero et al., 2011), a fact that should lead to a reduction in tree transpiration. As mentioned before, the magnitude of this reduction, however, is difficult to predict since it might depend on several environmental and tree factors. Therefore, currently it is not possible to estimate a precise water budget for RDI in citrus groves, even though there have been several studies that determined $\mathrm{K}_{\mathrm{c}}$ and $\mathrm{ET}_{\mathrm{c}}$ of citrus orchards (Castel, 2000; Villalobos et al., 2009). It is then important to gain some new insights on transpiration values of citrus trees under water stress conditions.

The use of sap flow methods is therefore particularly suited for RDI studies because they can help quantifying both: net tree transpiration reduction and the degree of plant water stress reached. Tree transpiration is not only function of soil water availability but also of the evaporative demand. Thus, a single measurement of plant transpiration may be meaningless unless it can be evaluated against a reference value obtained on trees growing without soil water limitations. Relative transpiration, obtained 
from the ratio between sap flow of water-stressed and well-watered trees, has been discussed during the last decades as a water stress indicator (Valancogne et al., 1997; Fernández et al., 2007). Moreover, other parameters derived from sap flow studies can also be used for water stress detection. Fernández et al. (2001) and Nadezhdina et al. (2007) found in water-stressed olive trees a subtle change in the shape of the sap velocity profile close to the cambium respect to well-watered trees. These authors suggested the possibility of using the ratio of sap flow in the inner/outer xylem regions as a water stress indicator with a potential use in automatic irrigation control. More recently, López-Bernal et al. (2010) observed in olive trees an increase in the nocturnal-to-diurnal sap flow ratio (N/D index) as the soil dried suggesting that the N/D index could also be a sensitive water status indicator.

\subsubsection{Canopy temperature}

The possibility of using plant temperature as an indicator of soil water availability for plants is known since decades ago (Gates, 1964). Plants under soil water deficit often decrease stomatal conductance, thereby reducing transpiration and increasing leaf temperature. The measurement of the infrared radiation emitted by the canopy can therefore be used as an indicator of plant water stress (Jackson, 1982; Jones, 1999; Merlot et al., 2002; Jones et al., 2002). However, it is important to keep in mind that stomatal aperture can be affected not only by soil water deficit, but also by other environmental and endogenous tree factors as well as biotic stresses such as pests and diseases (Jones et al., 2009). Besides, environmental 
conditions such as incoming radiative energy, air temperature and wind, plant morphology's aspects like canopy shape and leaf size, as well as plantcontrolling transpiration mechanisms have a direct influence on canopy temperature (Scherrer et al., 2011).

Thermal sensing can be used remotely allowing a large crop area to be measured, especially when thermal imaging is employed (Jones, 2004). Images can be taken by thermographic cameras installed on airborne platforms (Berni et al., 2009) or by hand-operated cameras assisted with auxiliary devices as tripods, platforms or cranes (Möller et al., 2007). In the case of hand-operated cameras, these can take images of individual plants or even portions of them (shady or sunlit zones) with a higher spatial resolution than aerial images (Jiménez-Bello et al., 2011). With the involvement of a single operator a large number of images can be obtained. The subsequent analysis of the images to determine mean canopy temperature of each single tree can be automated and speeded with methodologies as the one developed by Jiménez-Bello et al. (2011), which allows the analysis of images taken on individual trees without the participation of an operator, saving almost 16 minutes per image with respect to the manual process. Besides mean canopy temperature, the measurement of the intra-crown standard deviation has also been suggested by some authors as an indicator of water stress (Fuchs, 1990; GonzálezDugo et al., 2012). González-Dugo et al. (2012) observed in almond that the variability of $T_{c}$ increased during the early stages of water stress while diminished when the stress became more severe. However, in other woody plants such as grapevines intra-canopy variations in $\mathrm{T}_{\mathrm{c}}$ were not impacted by 
vine water status (Grant et al., 2007; Moller et al., 2007). Thus, studies in other perennial crops are needed to evaluate the feasibility of using intracanopy $\mathrm{T}_{\mathrm{c}}$ variability as an indicator of plant water status.

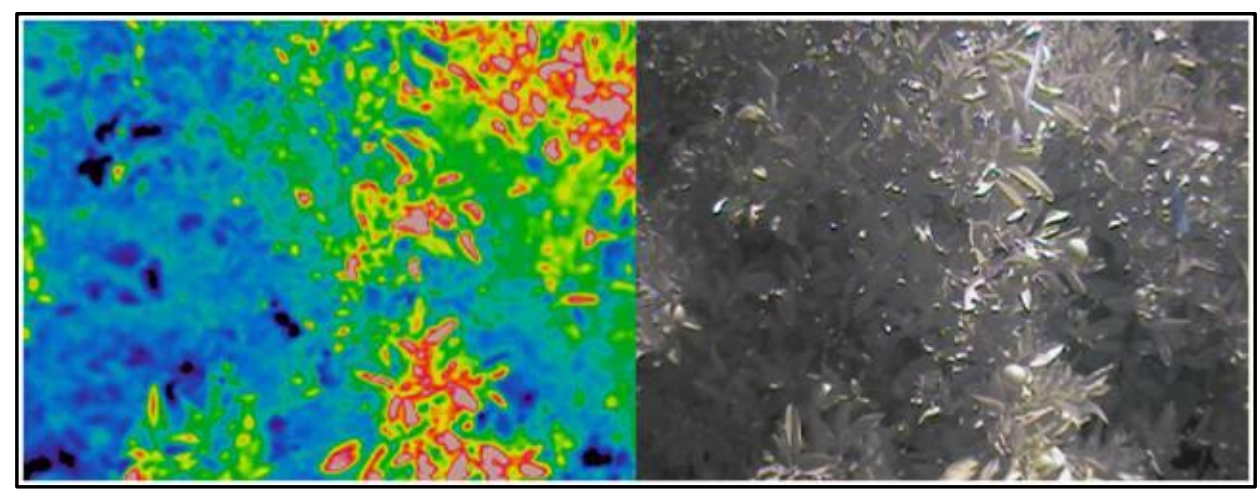

Figure 5 Visible and thermal image of a canopy citrus tree.

\subsection{Objectives}

As mentioned in previous sections González-Altozano and Castel (1999) determined in experimental orchards that moderate water restrictions (i.e. replacing only $50 \%$ of full crop evapotranspiration) during July and August successfully allowed reducing water application without neither yield nor fruit size reductions. They identified a threshold value of plant water stress determined by $\Psi_{\mathrm{s}}$ measurement of around -1.3 to $-1.5 \mathrm{MPa}$. Despite the promising results obtained by these authors, RDI in 'Clementina de Nules' trees is not a practice commonly applied in the area and growers are often reluctant to deliberately apply RDI based on the lack of more local research under commercial situation. 
The general goal of this work, which is divided into five experiments, was to provide growers with more reliable information on the use of RDI in commercial situations to optimize water management in two of the more typical citrus species planted in Valencia, 'Clementina de Nules' mandarin and the late-season-maturing orange cultivar 'Navel Lane Late'. Furthermore, the feasibility of using sap flow and canopy temperature measurements as alternative methods to stem water potential and stomatal conductance for monitoring tree water status in citrus was also evaluated.

The specific aims were: (1) to assess the extrapolation of previous research by González-Altozano and Castel (1999) under commercial situations using the plant water stress threshold values previously identified; (2) to assess the application of summer RDI strategies in a commercial grove of 'Navel Lane Late' testing the plant water stress threshold values identified for 'Clementina de Nules'; (3) to determine if there are differences in water stress sensitivity between 'Clementina de Nules' and 'Navel Lane Late'; (4) to determine sap flow (i.e. tree transpiration), based on the compensation heat pulse method, in well-watered and RDI trees studying how environmental fluctuations affect plant water use; (5) to explore the feasibility of using several indexes derived from sap flow measurements, such as relative transpiration, radial heat-pulse velocity pattern and nocturnal-to-diurnal sap flow ratio for plant water stress detection; (6) to assess the use of mean canopy temperature, obtained by thermal imaging, and temperature variability within the crowns as water stress indexes; (7) to test these water stress indexes in citrus and persimmon tree crops, which were selected because of their differences in leaf anatomy 
Introduction

(larger and thicker leaves in persimmon than in citrus) and differential stomatal response to VPD under favorable soil water conditions and; (8) to compare the classical methods employed to detect plant water stress, $\Psi_{\mathrm{s}}$ and $\mathrm{g}_{\mathrm{s}}$, with sap flow and canopy temperature measurements obtained with fixed infrared thermometer sensors and with a hand-operated thermographic camera. 
2 Materials and methods 
Materials and Methods

\subsection{Experiment 1: Summer RDI strategies in 'Clementina de Nules' citrus trees}

\subsubsection{Experimental plot}

The experiment was performed during five consecutive years (2007 to 2011), in a commercial 'Clementina de Nules' grove (Citrus clementina, Hort ex Tan) grafted on Carrizo citrange (Citrus sinensis, Osb. x Poncirus Trifoliata, Raf). Trees were planted in 1999 at a spacing of $6 \mathrm{~m} \mathrm{x} 4 \mathrm{~m}$. The grove belongs to the Cooperative of Liria, Valencia, Spain $\left(40^{\circ} \mathrm{N}, 0^{\circ} \mathrm{W}\right.$, and elevation $300 \mathrm{~m})$.

Soil was clay to clay loam texture, rich in calcium carbonate and with $21 \%$ by weight stones. Trees were drip irrigated with 8 emitters per tree, each delivering $4 \mathrm{l} \mathrm{h}^{-1}$ located on a double line. Each experimental unit was equipped with a water flow meter to register the amount of water applied. Irrigation water was of medium salinity, $\mathrm{EC}_{25}{ }^{\circ} \mathrm{C}$ of $1.20 \mathrm{dS} \mathrm{m}^{-1}$, and of alkaline reaction, $\mathrm{pH}$ 7.34. The mean annual amount of fertilizers applied to all the irrigation treatments tested through the irrigation system was 10432-80 kg ha ${ }^{-1}$ of $\mathrm{N}, \mathrm{P}_{2} \mathrm{O}_{5}$, and $\mathrm{K}_{2} \mathrm{O}$, respectively. These amounts were evenly distributed in weekly applications from March to September. Every winter, trees were hand pruned. The rest of cultural practices were those common for the area.

Irrigation scheduling was based on estimated $\mathrm{ET}_{\mathrm{c}}\left(\mathrm{ET}_{\mathrm{c}}=\mathrm{ET}_{\mathrm{o}} * \mathrm{~K}_{\mathrm{c}}\right)$. $\mathrm{ET}_{\mathrm{o}}$ was calculated from weather information obtained in an automated meteorological station located $4.2 \mathrm{~km}$ far from the orchard. At the beginning 
of the experiment, average $\mathrm{GC}$ of the trees was $33 \%$ and seasonal $\mathrm{K}_{\mathrm{c}}$ according to Castel (2000) was 0.48. However, during the season $\mathrm{K}_{\mathrm{c}}$ values varied from 0.38, in May, to 0.59 in October in concordance with the plant physiological cycle. During the warmest part of the season drip irrigation was applied daily, and it was controlled and adjusted weekly according to the estimated $\mathrm{ET}_{\mathrm{c}}$. Irrigation applied to each treatment and rainfall and $\mathrm{ET}_{\mathrm{o}}$ registered during the experimental period are reported in Table 4.

Table 4 Annual reference evapotranspiration $\left(\mathrm{ET}_{\mathrm{o}}\right)$, rainfall and irrigation applied in each experimental season. Irrigation volumes applied with (\%) savings ${ }^{a}$ in parentheses compared to the control treatment are also shown.

\begin{tabular}{|c|c|c|c|c|c|}
\hline \multirow[b]{2}{*}{ Year } & \multirow[b]{2}{*}{$\mathbf{E T}_{\mathbf{o}}(\mathbf{m m})$} & \multirow[b]{2}{*}{$\begin{array}{c}\text { Rainfall } \\
\text { (mm) }\end{array}$} & \multicolumn{3}{|c|}{ Irrigation $\left(\mathrm{mm}\right.$ year $\left.^{-1}\right)$} \\
\hline & & & Control & RDI-1 & RDI-2 \\
\hline 2007 & 1074 & 426 & 252 & $201(20)$ & $173(31)$ \\
\hline 2008 & 1046 & 553 & 332 & $259(22)$ & $253(24)$ \\
\hline 2009 & 1090 & 371 & 509 & $466(8)$ & $467(8)$ \\
\hline 2010 & 1009 & 530 & 418 & $364(13)$ & $351(16)$ \\
\hline 2011 & 1005 & 362 & 442 & $376(15)$ & $336(18)$ \\
\hline 2007-2011 & 1045 & 448 & 391 & 333 (15) & $316(19)$ \\
\hline
\end{tabular}

${ }^{a}$ Defined as:(1-(irrigation in the RDI treatment/irrigation in the control)) x100

\subsubsection{Irrigation treatments}

Three treatments were applied: (i) Control, irrigated during the whole season at $100 \% \mathrm{ET}_{\mathrm{c}}$; (ii) Moderate deficit irrigation (RDI-1), irrigated at around $50 \%$ of the control treatment since the end of the physiological 
fruit drop (i.e. mid July) until early-mid September (Table 5). Deficit irrigation was scheduled in order to avoid that $\Psi_{\mathrm{s}}$ went below -1.3 to -1.5 $\mathrm{MPa}$, a previously identified threshold value for avoiding fruit size reductions (González-Altozano and Castel, 1999); (iii) Severe deficit irrigation (RDI-2), irrigated with a $30-40 \% \mathrm{ET}_{\mathrm{c}}$ during the same months as RDI-1 with a threshold value of $\Psi_{\mathrm{s}}$ of -1.5 to-1.7 $\mathrm{MPa}$. During the rest of the season RDI treatments were irrigated as the control.

The statistical design was a randomized complete block with four replicates per treatment. Each experimental unit had three rows with seven trees per row and perimeter trees were used as guard, leaving five sampling trees per plot.

\subsubsection{Plant water status}

During the period of water restrictions, $\Psi_{\mathrm{s}}$ was measured weekly at solar midday with a pressure chamber (Model 600 Pressure Chamber Instrument), following the procedures described by Turner (1981). Determinations were carried out in two mature leaves, bagged in plastic bags and covered with silver foil at least one hour prior to measurements. Samples were taken from each of two trees per plot during the first experimental season and of three trees per plot during the rest of the years. Therefore, a total of eight trees per treatment were monitored with $\Psi_{\text {s }}$ readings in 2007 and 12 trees per treatment the rest of the seasons.

Plant water stress suffered by the RDI treatments during the deficit irrigation period was computed as the water stress integral $\left(S_{\psi}\right)$ calculated 
from the midday stem water potential according to the modified equation proposed by Myers (1988):

$$
S_{\psi}=\left|\sum_{i=0}^{i=t}\left(\bar{\psi}_{i, i+1}-c\right) n\right|
$$

where $\psi_{i, i+1}$ is the mean $\Psi_{\mathrm{s}}$ for any interval $i, i+1, c$ is the maximum $\Psi_{\mathrm{s}}$ ($0.3 \mathrm{MPa}$ ) and $n$ is the number of days in the interval.

Table 5 Day of the year (DOY) in which water restrictions began and ended within each experimental season.

\begin{tabular}{ccc}
\hline Experimental season & Onset of treatments & End of treatments \\
$2007-2008$ & 184 & 234 \\
$2008-2009$ & 197 & 266 \\
$2009-2010$ & 209 & 257 \\
$2010-2011$ & 201 & 257 \\
$2011-2012$ & 200 & 255 \\
\hline
\end{tabular}

\subsubsection{Fruit growth measurements}

Fruit equatorial diameter was measured in the field weekly, from July until harvest, with an electronic caliper (Mitutoyo, Kawasaki, Japan) on 20 selected fruit per experimental unit (80 fruit per treatment). Besides, random samples of 12 fruit per experimental unit were collected fortnightly for destructive measurement of physical dimensions, fresh and dry weight. Fruit were collected from guard trees of each treatment, measured with a digital caliper, weighed and dried at $65^{\circ} \mathrm{C}$ until constant dry weight. 


\subsubsection{Yield determinations}

Yield and number of fruit per tree were determined at the time of commercial harvest on each experimental tree. Average fruit weight was determined using a commercial grading machine (Polyfruit electronic sizer, Food Machinery Española, S.A., Valencia, Spain). Harvest was carried out by the end of November in 2007 and by mid December the rest of the seasons. Water use efficiency (WUE) was calculated as yield divided by irrigation applied plus effective rainfall. Each season, economic returns were calculated considering the relative weight of fruit and the prices received by growers for each commercial category set by the Cooperative. Water productivity was calculated according to Fereres and Soriano (2007) as the incomes for selling the fruit divided by irrigation applied plus effective rainfall.

\subsubsection{Fruit quality}

A sample of 50 fruit per experimental unit (four independent samples per treatment) was collected randomly at harvest time from selected trees where yield was concurrently measured. A subsample of 25 fruit was used to determine fruit quality in that moment, while the other 25 fruit were stored at $4{ }^{\circ} \mathrm{C}$ and $82 \%$ relative humidity for 22 days to determine fruit composition after a cold storage period (post-harvest sample). In 2009 and 2011, the post-harvest samples were lost due to failure of the storage cooling system. 
Materials and Methods

Fruit were weighed, squeezed with a juice machine (Zumonat, Model C-40, Barcelona, Spain) and filtered. Juice total soluble solids content (TSS) was measured with a temperature compensated digital refractometer (Atago, Palette PR-101), and juice titratable acidity (TA) was determined by titration with $0,1 \mathrm{~N} \mathrm{NaOH}$ (Metrohm, 785 DMP Titrino). The maturity index was expressed as TSS divided TA.

\subsubsection{Trunk growth}

Trunk perimeter was measured with a metric tape at the beginning and at the end of each season. Measurements were taken at marked sections located about $0.05 \mathrm{~m}$ above the graft and approximately $0.25 \mathrm{~m}$ above the ground in all sampling trees of each treatment. Pruning weights were also recorded each year in the same trees where trunk perimeter was measured.

\subsubsection{Statistical analysis}

Data were analyzed using analysis of variance procedure and means were separated by Dunnett's test against the Control and contrast between pair of treatments according to the mixed procedure of SAS (SAS Institute 1994).

\subsection{Experiment 2: Summer RDI strategies in 'Navel Lane Late' citrus trees}

\subsubsection{Experimental plot and irrigation treatments}

The experiment was performed during four consecutive seasons, (2007 to 2010), in a 1.6-ha commercial citrus grove located in Chulilla, 
Valencia, Spain $\left(39^{\circ} 40^{\prime} \mathrm{N}, 0^{\circ} 50^{\prime} \mathrm{W}\right)$. At the beginning of the experiment trees were seven years old. Plant material used was the cv. 'Navel Lane Late' (Citrus sinensis (L) Osbeck) grafted on Carrizo citrange (Citrus sinensis, Osb. x Poncirus Trifoliata, Raf). The grove was planted at a spacing of $6 \mathrm{~m} \mathrm{x} 4 \mathrm{~m}$. Soil was clay to clay loam texture, rich in calcium carbonate and with $11 \%$ by weight stones. Irrigation water was of medium salinity, $\mathrm{EC}_{25}{ }^{\circ} \mathrm{C}$ of $1.22 \mathrm{dS} \mathrm{m}^{-1}$ and of alkaline reaction, $\mathrm{pH} 7.61$.

Prior to the experiment, trees were irrigated via surface irrigation. In the spring of 2007, the irrigation system was changed to drip irrigation and adapted to allow the application of different treatments. Thus, during the experiment, trees were drip irrigated with eight emitters per tree, each delivering $4 \mathrm{~L} \mathrm{~h}^{-1}$ located on a double line separated $1 \mathrm{~m}$ at each side from the trees' line.

The mean annual amount of fertilizers applied similarly to all the treatments through the irrigation system was 104-32-80 $\mathrm{kg} \mathrm{ha}^{-1}$ of $\mathrm{N}, \mathrm{P}_{2} \mathrm{O}_{5}$, and $\mathrm{K}_{2} \mathrm{O}$, respectively. These amounts were evenly distributed in weekly applications from March to September.

As in the experiment with 'Clementina de Nules', irrigation scheduling was based on estimated $\mathrm{ET}_{\mathrm{c}}$. $\mathrm{ET}_{\mathrm{o}}$ was calculated according to Penman-Monteith formulation from weather information obtained in an automated meteorological station located $4 \mathrm{~km}$ from the orchard. $\mathrm{K}_{\mathrm{c}}$ varied among months depending on the crop phenological stage. Spring flush growth for 'Navel Lane Late' in this area usually occurs during March, flowering by early May, the physiologic fruit drop by early July and harvest from late February to mid April depending on the market's requirements. At 
the beginning of the experiment average GC was $27 \%$ of the soil allotted per tree and the corresponding seasonal $\mathrm{K}_{\mathrm{c}}$, according to Castel (2000), was 0.42. Along the season $K_{c}$ values for each month from March to October were respectively, $0.41,0.38,0.34,0.38,0.42,0.49,0.46$ and 0.52 . During the warmest part of the season drip irrigation was applied daily, and it was controlled and adjusted weekly according to the estimated $\mathrm{ET}_{\mathrm{c}}$. Irrigation applied to each treatment, rainfall and $\mathrm{ET}_{\mathrm{o}}$ registered during the experimental period are reported in table 6 .

Three irrigation treatments were applied: (i) Control, irrigated during the whole season at $100 \% \mathrm{ET}_{\mathrm{c}}$; (ii) Moderate deficit irrigation (RDI-1), irrigated at around $50 \%$ of the control treatment since the end of the physiological fruit drop (i.e. mid July) until September $20^{\text {th }}$ (day of the year (DOY) 180-263), September 26 ${ }^{\text {th }}$ (DOY 196-270), September $29^{\text {th }}$ (DOY 201-272) and September 14 ${ }^{\text {th }}$ (DOY 201-267) in 2007, 2008, 2009 and 2010, respectively. In addition, deficit irrigation was scheduled in order to avoid that $\Psi_{\mathrm{s}}$ went below -1.3 to $-1.5 \mathrm{MPa}$, the threshold value identified for avoiding fruit size reductions in 'Clementina de Nules' (González-Altozano and Castel, 1999); (iii) Severe deficit irrigation (RDI-2), irrigated at 30-40\% of the control during the same period as RDI-1 and with a threshold $\Psi_{\text {s }}$ value of -1.5 to-1.7 $\mathrm{MPa}$. When $\Psi_{\mathrm{s}}$ went below the threshold values mentioned, irrigation was modified in the next week by about $+25 \%$. During the rest of the season both RDI treatments were irrigated as the control. 
Materials and Methods

Table 6 Annual reference evapotranspiration $\left(\mathrm{ET}_{\mathrm{o}}\right)$, rainfall and irrigation applied in each experimental season. Irrigation volumes applied with (\%) savings $^{\mathrm{a}}$ in parentheses compared to the control treatment are also shown.

\begin{tabular}{lccccc}
\hline Year & ET $_{\mathbf{o}}(\mathbf{m m})$ & Rainfall $(\mathbf{m m})$ & Control & RDI-1 & RDI-2 \\
2007 & 1143 & 581 & 295 & $206(30)$ & $182(38)$ \\
2008 & 1186 & 614 & 343 & $282(18)$ & $278(19)$ \\
2009 & 1341 & 342 & 472 & $383(19)$ & $368(22)$ \\
2010 & 1214 & 469 & 517 & $456(12)$ & $435(16)$ \\
$\mathbf{2 0 0 7 - 2 0 1 0}$ & $\mathbf{1 2 2 1}$ & $\mathbf{5 0 2}$ & $\mathbf{4 0 7}$ & $\mathbf{3 3 2}(\mathbf{1 8})$ & $\mathbf{3 1 6 ( 2 2})$ \\
\hline
\end{tabular}

${ }^{a}$ Defined as:(1-(irrigation in the RDI treatment/irrigation in the control)) $x 100$

The statistical design was a randomized complete block with four replicates per treatment. Each experimental unit had three rows with twelve to twenty trees per row. Perimeter trees were used as guard leaving at least ten sampling trees per plot.

\subsubsection{Plant water status}

During the period of water restrictions, stem water potential was measured weekly at solar midday with two pressure chambers (Model 600 Pressure Chamber, PMS Instrument Company, Albany, USA), following procedures described by Turner (1981).

As in the 'Clementina de Nules' experiment, determinations were carried out in two mature leaves per tree bagged in plastic bags and covered with silver foil at least one hour prior to measurements. A total of eight trees per treatment were monitored with $\Psi_{\mathrm{s}}$ readings. Water stress integral $\left(\mathrm{S}_{\psi}\right)$ 
was calculated from the midday stem water potential according to the equation shown in section 2.1.3.

\subsubsection{Trunk growth, yield and fruit quality}

Tree vegetative growth, yield components and fruit quality were determined as in the Experiment 1 with 'Clementina de Nules' in a minimum of 10 sampled trees per experimental unit. For each experimental season, harvest took place on February $2^{\text {nd }}, 2008$; April $6^{\text {th }}, 2009$; April $15^{\text {th }}$, 2010 and; April 7 ${ }^{\text {th }}, 2011$.

\subsubsection{Statistical analysis}

Data were analyzed using the SAS statistical package (version 9.0; SAS Institute, Cary, NC). Analysis of multiple regression was performed using the "REG" procedure while analysis of variance according to the "MIXED" procedure. Means were separated by Dunnett's test and contrast between the RDI levels.

\subsection{Comparison between 'Clementina de Nules' and 'Navel Lane Late' sensitivity to deficit irrigation}

The sensitivity of 'Clementina de Nules' to deficit irrigation was compared with that of 'Navel Lane Late' orange trees by means of data obtained from the RDI trials performed from 2007 to 2010 in the orchards described previously in this section (2.1.1 and 2.2.1). 


\subsubsection{Data analysis}

Sensitivity of both species to deficit irrigation was analyzed by comparing the relationships between fruit weight, TSS, TA and maturity index at harvest, and the average $\Psi_{\mathrm{s}}$ registered during the period of water restrictions. The slopes of the fruit weight against $\Psi_{\mathrm{s}}$ relations for each species were compared statistically using the multiple regression analysis from the Statgraphics 5.0 program.

\subsection{Experiment 3: Usefulness of sap flow measurements as a continuous plant water stress indicator of citrus trees}

\subsubsection{Experimental plots and treatments}

The experiment was performed during 2009 and 2010 in the mandarin ('Clementina de Nules') grove described in section 2.1.1, and during 2010 in the 'Navel Lane Late' grove described in section 2.2.1. The climate in the areas of study is Mediterranean with an average annual value for the experimental seasons of $\mathrm{ET}_{\mathrm{o}}$ of $1100 \mathrm{~mm}$ in Liria and $1273 \mathrm{~mm}$ in Chulilla, and an annual rainfall of $401 \mathrm{~mm}$ and $494 \mathrm{~mm}$, respectively.

Although two RDI strategies were tested in both groves, only two control and two of the most stressed trees of each grove (RDI-2 treatment) were used for this experiment. Average trunk diameter and GC of sampled trees within each experimental season are shown in table 7. 


\subsubsection{Sap flow measurements}

In 'Clementina de Nules' sap flow was estimated by the CHP method using the heat-pulse velocity system developed by Green and Clothier (1988) with gauges produced by TranzFlo NZ Ltd (Figure 6). Two control and two RDI trees were instrumented in July 2009 with one unit of two different types of gauges per tree.

Table 7 Average and standard deviation of trunk diameter (trunk $\varnothing, \mathrm{cm}$ ) and canopy ground cover (GC, \%) of the 'Clementina de Nules' and 'Navel Lane Late' trees.

\begin{tabular}{ccccc}
\hline & \multicolumn{2}{c}{ 'Clementina de Nules' } & \multicolumn{2}{c}{ 'Navel Lane Late' } \\
\cline { 2 - 5 } $\mathbf{2 0 0 9}$ & Control & RDI & Control & RDI \\
trunk $\emptyset$ & $12.1 \pm 0.1$ & $11.8 \pm 0.2$ & - & - \\
$\mathbf{G C}$ & $34.7 \pm 1.4$ & $31.9 \pm 2.7$ & - & - \\
$\mathbf{2 0 1 0}$ & & & & \\
trunk $\emptyset$ & $12.9 \pm 0.3$ & $12.3 \pm 0.5$ & $13.9 \pm 2.3$ & $12.5 \pm 0.3$ \\
GC & $34.7 \pm 1.4$ & $32.5 \pm 2.6$ & $33.4 \pm 3.5$ & $33.7 \pm 3.7$ \\
\hline
\end{tabular}

A heat pulse gauge was composed of a pair of temperature sensing probes and a linear heater. A control box and a data-logger (model CR1000, Campbell Scientific Inc., Utah, USA) powered by a $12 \mathrm{~V}$ battery were used to drive the pulses and store data. Each gauge measured temperature differences between downstream $(10 \mathrm{~mm})$ and upstream $(-5 \mathrm{~mm})$ teflon probes respect to the linear heater by means of thermocouples located at 
four different xylem depths: i) type 1 gauges: 5, 12, 21 and $32 \mathrm{~mm}$ below the cambium and ii) type 2 gauges: 10, 17, 26 and $38 \mathrm{~mm}$ below the cambium. Type 1 gauges were installed into the north side of the main trunk while type 2 gauges were installed into the south side. Probes were installed using drilling bits of $1.8 \mathrm{~mm}$ external diameter guided by a metallic plate with pre-drilled holes. Heat pulse velocity values were corrected for wounding using the coefficients of Swanson and Whitfield (1981) with an estimated wound size of $2.4 \mathrm{~mm}$. The most recommended procedure to obtain accurate sap flow estimates would be to determine the actual wound size value after the experiment by cutting the trunk. This is feasible in experimental conditions, however when using sap flow gauges in commercial applications, as was this case, it is not possible to determine the actual wound size. In these situations, the wound size is normally taken from previous research and, for instance, in this experiment the value used was based on Barrett et al. (1995), whose anatomical investigations showed that the total wound normally extends about $0.3 \mathrm{~mm}$ to either side of the drilling hole.

Sap flow was measured every 30 minutes and the minimum heat velocity values accepted were those equivalents to crossing times of $330 \mathrm{~s}$ (Green et al., 2003). The pulse duration was of one second.

'Navel Lane Late' trees were instrumented in February 2010 with two identical gauges (IAS-CSIC, Córdoba) that measured temperature differences between two stainless steel probes, one downstream $(10 \mathrm{~mm})$ and one upstream $(-5 \mathrm{~mm})$ with respect to a linear heater $(2.0 \mathrm{~mm}$ of external diameter). The method employed was the CAG routine developed 
by Testi and Villalobos (2009) to measure low sap velocities. Temperature measurements were obtained by means of ultra-thin thermocouples located at $5,15,25$ and $35 \mathrm{~mm}$ within the trunk. Probes were installed using a metallic plate with pre-drilled holes and drilling bits of $2.1 \mathrm{~mm}$ external diameter so heat pulse velocity values were corrected using an estimated wound size of $2.7 \mathrm{~mm}$ (Figure 7). Heat pulses of two seconds were applied every 15 minutes. The temperature differences (above-below) were measured during $10 \mathrm{~s}$ before the pulse to check the stability of the readings. After the pulse, differential temperature $(\Delta \mathrm{T})$ readings were averaged during $180 \mathrm{~s}$.

Wood samples of $5 \mathrm{~mm}$ diameter were taken in 10 trees per orchard with a Pressler type core sampler. Samples were weighed and oven-dried at $65^{\circ} \mathrm{C}$ to constant weight to determine the wood bulk density and moisture content. Wood $\left(\mathrm{F}_{\mathrm{M}}\right)$ and water $\left(\mathrm{F}_{\mathrm{L}}\right)$ volumetric fractions were respectively, 0.43 and 0.35 in 'Clementina de Nules', and 0.46 and 0.37 in 'Navel Lane Late'. These values were used to convert corrected heat-pulse velocity $\left(\mathrm{V}_{\mathrm{c}}\right)$ to sap flux density $\left(\mathrm{J}_{\mathrm{s}}, \mathrm{cm} \mathrm{h}^{-1}\right)$ as in Becker and Edwards (1999):

$$
J=\left(0.441 F_{M}+F_{L}\right) V_{c}
$$

Volumetric sap flux in the trunk was obtained by means of the weighted average method proposed by Hatton et al. (1990), in which the annular cross-section of the tree is divided into $n$ concentric annuli (as many as the sensors placed at different depths) so that the inner radius $r_{k}$ of annulus $\mathrm{k}$ occurs midway between sensors $\mathrm{k}$ and $\mathrm{k}+1$, where $\mathrm{k}=1, \ldots, \mathrm{n}-1$, numbered from the cambium. The information from each $\mathrm{k}$ sensor is 
weighed by the proportion (pk) of the total sapwood conducting area it represents:

$$
p_{k}=\left(r_{k}^{2}-r_{k-1}^{2}\right) /\left(a^{2}-b^{2}\right)
$$

where $a$ is the radius at the cambium $\left(\mathrm{r}_{0}=\mathrm{a}\right)$ and $b$ is the radius at the heartwood $\left(r_{n}=b\right)$. Flux $(Q)$ was obtained as the weighted average of sap flux densities, weighed by the area of sapwood associated with each sensor:

$$
Q=\sum_{k=1}^{n} \pi\left(r_{k}^{2}-r_{k-1}^{2}\right) J
$$

Sap flow of control and water-stressed treatments was calculated as the average of the two trees per treatment. In order to take into account the existing differences in tree shaded area among trees, sap flow of each individual tree was weighed according to the ratio between the average canopy ground cover of the four sampled trees and the canopy ground cover of each specific sampled tree.
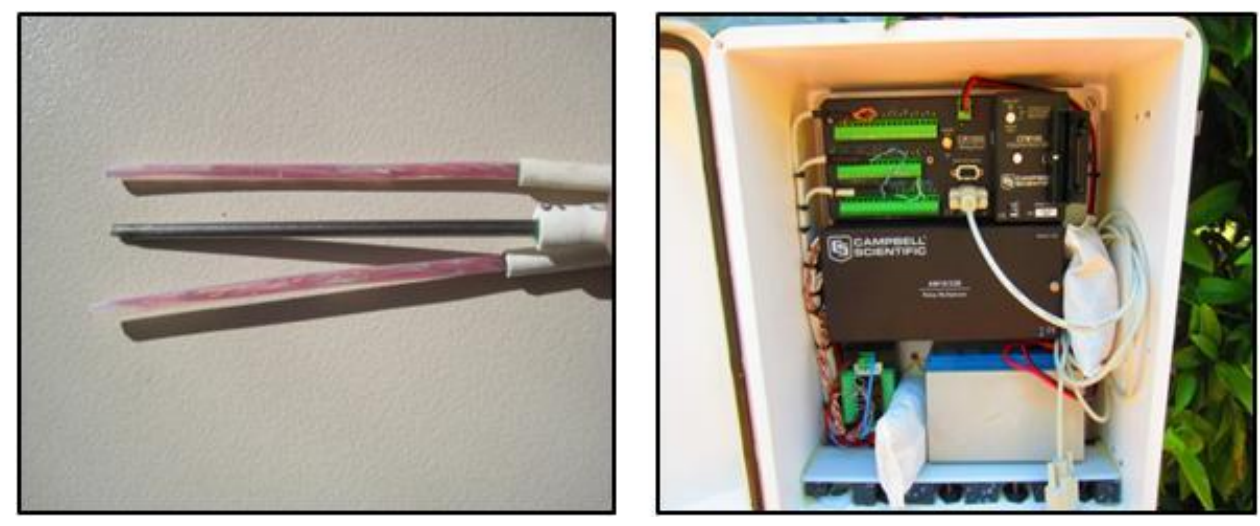

Figure 6 Sap flow sensors and datalogger used in 'Clementina de Nules' trees. 

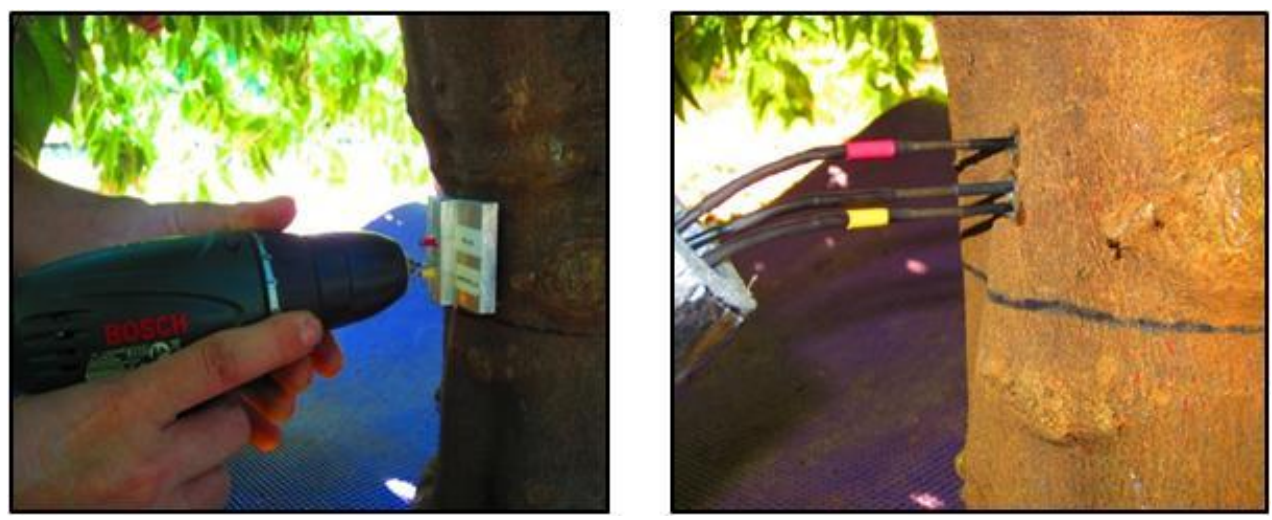

Figure 7 Installation of the sap flow sensors employed in 'Navel Lane Late' trees.

\subsubsection{Plant water status determinations}

During the RDI period, tree water status was determined weekly by $\Psi_{\mathrm{s}}$. Measurements were taken in two mature bagged leaves per tree at solar midday, with a pressure chamber (Model 600 PMS Instrument) following the recommendations of Turner (1981).

\subsubsection{Data analysis}

Regressions between pair of variables were performed with the regression models "REG" procedure of the SAS statistical package (version 9.0; SAS Institute, Cary, NC).

Two indexes derived from the continuous sap flow measurement were used. The relative transpiration (RT) was calculated as the daily transpiration of control trees divided by that of RDI trees. The nocturnal to 
diurnal sap flow ratio (N/D) was obtained on each treatment as the ratio of daily sap flow values reported from 10:30 to 16:30 and values obtained during the night hours from 21:00 to 06:00. All calculations were based on the averages of the two trees per treatment. Previous to the water restrictions, when both control and RDI trees were equally irrigated, unexpectedly, N/D in 'Navel Lane Late' was 1.34 higher in control than in RDI trees. This difference was not associated to any difference in water status, thus it was considered a measurement offset. The ratio of 1.34 was then employed to normalize the N/D values obtained in the RDI trees of this species to better compare the evolution of N/D in both irrigation treatments during the period of water restrictions.

\subsection{Experiment 4: Usefulness of thermography for plant water stress detection in citrus and persimmon trees}

\subsubsection{Plot characteristics and irrigation treatments}

\subsubsection{Persimmon experiment}

The experiment was carried out during two consecutive seasons, 2009 and 2010, in a 0.52-ha orchard located in Manises, Valencia, Spain $\left(39^{\circ} 30^{\prime} \mathrm{N}, 0^{\circ} 24^{\prime} \mathrm{E}\right.$, elevation $\left.44 \mathrm{~m}\right)$ planted with eight-year-old Persimmon (Diospyros Kaki) trees, cv. "Rojo Brillante". Trees were planted at a spacing of $5.5 \mathrm{~m} \mathrm{x} 4 \mathrm{~m}$ and grafted on Diospyrus Lotus. The soil was calcareous; of sandy loam to sandy clay loam texture with an effective depth of $0.8 \mathrm{~m}$. Trees were drip irrigated with two laterals per row and eight pressure compensated emitters of $4 \mathrm{~L} \mathrm{~h}^{-1}$ per tree. At the beginning of the 
experiment, trees had a canopy ground cover of $39 \%$ of the soil surface area allotted per tree.

The experimental orchard was designed to test four irrigation regimes but only two of them were used for the purpose of this experiment: (i) control, irrigated at $100 \% \mathrm{ET}_{\mathrm{c}}$ during the whole season and, (ii) water stressed (WS), irrigated at $50 \% \mathrm{ET}_{\mathrm{c}}$ from May $22^{\text {nd }}$ (DOY 142) to August $18^{\text {th }}$ (DOY 230) in 2009 and from May 21 $1^{\text {st }}$ (DOY 141) to August $27^{\text {th }}$ (DOY 239) in 2010.

The experimental layout was a randomized complete block design with three replicates per treatment and 6-7 sampled trees per replicate. Perimeter trees were used as guard.

\subsubsection{Citrus experiment}

The citrus experiment was performed during 2009 and 2010 in the 1.7-ha grove located in Chulilla (Valencia, Spain), planted with 'Navel Lane Late' trees described in detail in section 2.2.1, where three irrigation treatments were being tested: (i) control, irrigated at $100 \% \mathrm{ET}_{\mathrm{c}}$ during the whole season; (ii) mild water stressed (RDI-1), irrigated at $50 \% \mathrm{ET}_{\mathrm{c}}$ from last July to mid September and at full dose during the rest of the season; and (iii) severe water stressed (RDI-2), irrigated at $35 \% \mathrm{ET}_{\mathrm{c}}$ during the same period as RDI-1.

As mentioned before, the experimental layout was a randomized complete block design with four replicates per treatment and at least 10 sampled trees per replicate. Perimeter trees were used as guard. 


\subsubsection{Plant water status measurements}

During the period of water restrictions plant water status was periodically determined in both orchards by means of $\Psi_{\mathrm{s}}$ and canopy temperature $\left(\mathrm{T}_{\mathrm{c}}\right)$ measurements. In addition, in persimmon trees $\mathrm{g}_{\mathrm{s}}$ was also measured.

$\Psi_{\mathrm{s}}$ was measured as in the previous experiments at solar midday with a pressure chamber (Model 600 Pressure Chamber, PMS Instrument Company, Albany, USA) following the recommendations of Turner (1981). Measurements were performed in two mature leaves per tree, in three trees per replicate in the persimmon experiment and two trees per replicate in the citrus one. Thus, $\Psi_{\mathrm{s}}$ was measured in a total of 24 and 18 trees in the citrus and persimmon orchards, respectively.

$\mathrm{G}_{\mathrm{s}}$ was measured at noon only in the persimmon orchard with a leaf porometer (SC-1 Porometer, Decagon, WA, USA). Measurements were carried out in five fully exposed leaves per tree and three trees per replicate.

\subsubsection{Image acquisition and processing}

$\mathrm{T}_{\mathrm{c}}$ was measured at noon with an infrared thermal camera TH9100 WR (NEC Avio Infrared Technologies Co., Ltd., Tokio, Japan; Figure 8). The camera had a precision of $\pm 2 \%$ of reading and was equipped with an angular field of view of $42.0 \times 32.1^{\circ}$. It had a visible of $752 \times 480$ pixels and a $320 \times 240$ pixel microbolometer sensor, sensitive in the spectral range of 8 and $14 \mu \mathrm{m}$. The emissivity was set at 0.98 , value indicated for healthy vegetation by Monteith and Unsworth (2008). 

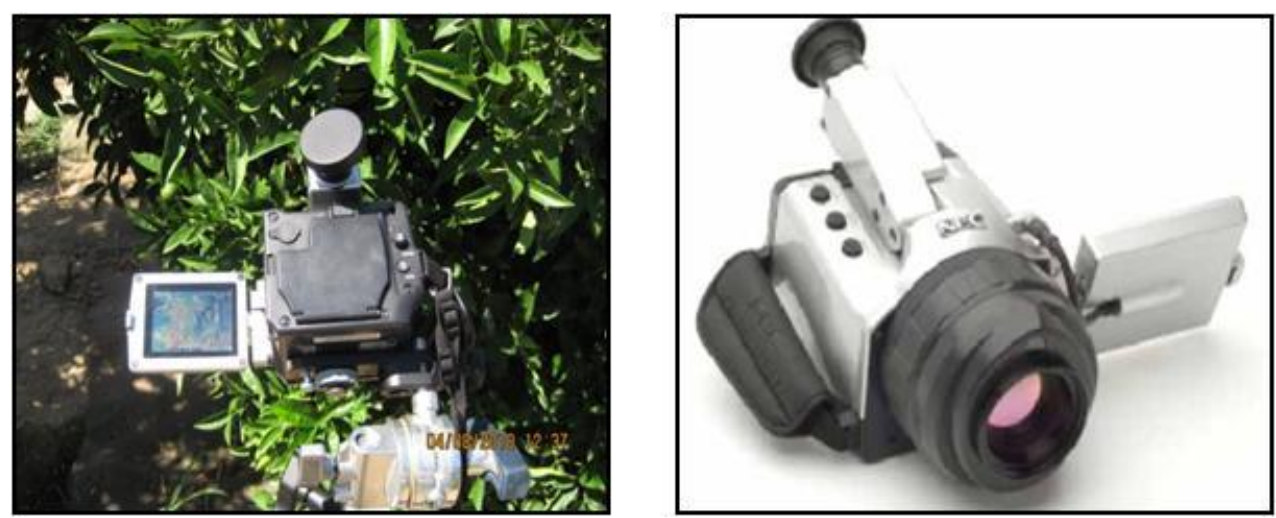

Figure 8 Thermographic camera used for the canopy temperature measurements

In 2009, $T_{c}$ was measured in both sunlit $\left(T_{c}\right.$ sunlit) and shaded ( $\mathrm{T}_{\mathrm{c}}$ shady) sides of the crowns by taking frontal thermal images from a distance of $3 \mathrm{~m}$ in persimmon trees and 1-2 $\mathrm{m}$ in the citrus ones. Pictures were taken in four representative days for persimmon (DOY 170, 205, 226 and 240) and in seven days for citrus (DOY 204, 218, 225, 232, 239, 246 and 253).

Based on the results obtained in 2009, images were only taken from the sunlit side of the trees in 2010. During this season pictures were taken in nine days for the persimmon orchard (DOY 138, 155, 169, 176, 190, 204, 211, 218 and 232) and five days for the citrus one (DOY 216, 224, 238, 246 and 258). Additionally, in the citrus experiment, the camera was assisted with a tripod and mounted $1 \mathrm{~m}$ above the trees pointing vertically downward to take pictures of the leaves most directly exposed to the solar radiation on DOY 224, 238 and 246. These pictures were only taken in the control and the most stressed trees (RDI-2 treatment). Furthermore, during DOY 239 for 
Materials and Methods

persimmon and 253 for the citrus orchard, pictures of the sampled trees were taken by an operator mounted on a truck-crane pointing downward from a height of $12 \mathrm{~m}$ above the ground (Figure 9). Given the camera optical and resolution characteristics and that the average canopy height was $2.5 \mathrm{~m}$, a picture taken from $12 \mathrm{~m}$ height represented a pixel size of $5.1 \mathrm{~cm}^{2}$ at canopy level.

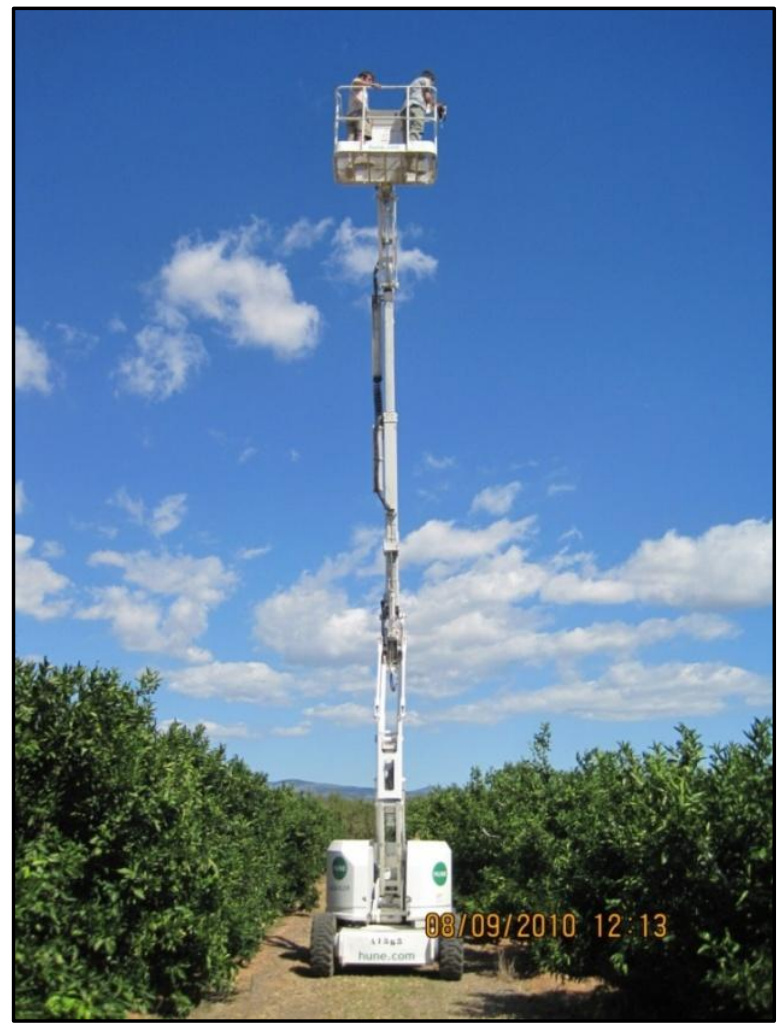

Figure 9 Truck-crane employed for the canopy temperature measurements. 
Images were processed with the ArcGIS 9.3 software (ESRI, Readlands, USA) according to the automated method described by JiménezBello et al. (2011). For the general data analysis, $T_{c}$ of each single tree was obtained from the average temperature of all the leaves integrated in the image.

In addition, temperature variability within the crowns (standard deviation) was analyzed in days with $\Psi_{\mathrm{s}}$ differences between treatments above $0.7 \mathrm{MPa}$. Standard deviation $(\sigma)$ within trees was calculated as:

$$
\sigma=\sqrt{\frac{\sum\left(x_{i}-\bar{x}\right)^{2}}{(n-1)}}
$$

where $n$ is the number of pixels, $x_{i}$ is the temperature value for a given pixel and $\bar{x}$ is the mean temperature of all the pixels from the canopy.

The crop water stress index (CWSI) was also determined only in the 2010 season of the citrus experiment. CWSI was calculated according to Idso et al. (1981):

$$
C W S I=\frac{\left(T_{c}-T_{a}\right)-\left(T_{c}-T_{a}\right)_{L L}}{\left(T_{c}-T_{a}\right)_{U L}-\left(T_{c}-T_{a}\right)_{L L}}
$$

where $\left(T_{c}-T_{a}\right)$ is canopy - air temperature differential, $\left(T_{c}-T_{a}\right)_{L L}$ the expected lower limit of $\left(\mathrm{T}_{\mathrm{c}}-\mathrm{T}_{\mathrm{a}}\right)$ for a tree transpiring at the potential rate, and $\left(T_{c}-T_{a}\right)_{U L}$ the expected differential for a non-transpiring canopy. The upper and lower limits of $\left(\mathrm{T}_{\mathrm{c}}-\mathrm{T}_{\mathrm{a}}\right)$ were obtained by using wet and dry reference surfaces as suggested by Jones et al. (2002). As a reference for $\left(T_{c}\right.$ $\left.-\mathrm{T}_{\mathrm{a}}\right)_{\mathrm{LL}}$, wetted leaves sprayed with water previous to the measurements 
were employed. $\left(T_{c}-T_{a}\right)_{U L}$, was obtained from leaves impregnated with petroleum-jelly.

\subsubsection{Data analysis}

Data were analyzed using analysis of variance procedure and means were separated by Dunnett's test and contrast between pair of treatments according to the mixed procedure of SAS (SAS Institute, 1994).

The different water stress indicators $\left(\Psi_{\mathrm{s}}, \mathrm{gs}, \mathrm{T}_{\mathrm{c}}\right.$ and CWSI $)$ were assessed by means of a sensitivity analysis (sensitivity defined as signal to noise ratio) as proposed by Goldhamer and Fereres (2001). Thus, when there were significant differences between treatments, the value "signal" for $\Psi_{\mathrm{s}}, \mathrm{T}_{\mathrm{c}}$ and CWSI was calculated as the ratio between the average value for the water-stressed and control treatments while for $\mathrm{g}_{\mathrm{s}}$ it was obtained from the ratio between the average value for the control and water-stressed treatments. In all cases the "noise" was the average coefficient of variation among trees from the same treatments as the signal value.

\subsection{Experiment 5: Comparison of different plant water stress indicators for citrus trees}

\subsubsection{Experimental plot and irrigation treatments}

The experiment was performed during the summer of 2011 in 12year-old 'Clementina de Nules' trees from the orchard described in detail in section 2.1 
Materials and Methods

The assessment of the different water status indicators was carried out in a total of 11 trees under three irrigation treatments: (i) a control treatment, made up of four trees irrigated at $100 \% \mathrm{ET}_{\mathrm{c}}$; (ii) a RDI treatment made up of other four trees irrigated at $35 \% \mathrm{ET}_{\mathrm{c}}$ from mid July to mid September and; (iii) three additional trees in which irrigation was withdrew during five consecutive weeks (NI) and then resumed as in the RDI treatment.

\subsubsection{Sap flow measurements}

Sap flow was determined by the CHP method in the two control and RDI trees employed in the experiment 3. These trees were equipped with two gauges (TranzFlo NZ Ltd) per tree oriented north and south side, with thermocouples located at 5, 12, 21 and $32 \mathrm{~mm}$ below the cambium. Two additional trees from each treatment were equipped with four gauges (IASCSIC, Córdoba) per tree located at north, south, east and west side of the trunk, with thermocouples at 5, 15, 25 and $35 \mathrm{~mm}$ depth from the cambium (Figure 10). Control trees had an average GC of $40.6 \%$ and a trunk diameter of $13.3 \mathrm{~cm}$ while in the RDI trees these values were of $39.7 \%$ and $13 \mathrm{~cm}$, respectively.

A control box and a data-logger (model CR1000, Campbell Scientific Inc., Utah, USA) powered by a $12 \mathrm{~V}$ battery were used to drive the pulses and store the data every 30 minutes. 


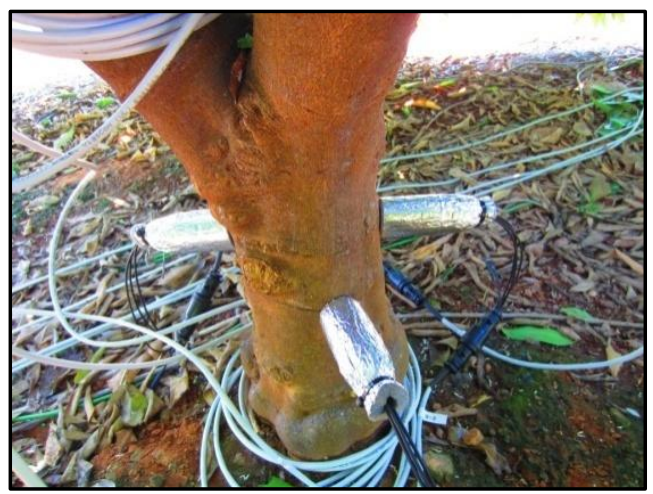

Figure 10 Distribution of the sensors installed in 'Clementina de Nules' trees.

Sap flux was calculated as described in experiment 3 (section 2.4.2). Sap flow of control and RDI treatments was obtained from the average of the four trees per treatment normalized by tree canopy ground cover (average canopy ground cover of the four sampled trees divided by the canopy ground cover of each single tree).

\subsubsection{Canopy temperature measurements}

$\mathrm{T}_{\mathrm{c}}$ was measured continuously in three control, RDI and NI trees with fixed infrared thermometer sensors (IRTs; Calex Model; Figure 11). Sensors were installed over the canopies pointing vertically downward to focus on the most exposed leaves to the solar radiation. In control and RDI trees, IRTs were installed approximately $0.9 \mathrm{~m}$ over the canopies allowing a field of view $\left(\alpha=28.08^{\circ}\right)$ of around $0.16 \mathrm{~m}^{2}$. In NI trees, however, sensors were installed $0.6 \mathrm{~m}$ over the trees so the field of view was of $0.07 \mathrm{~m}^{2}$. A 
data-logger (model CR1000, Campbell Scientific Inc., Utah, USA) was used to store data every minute.
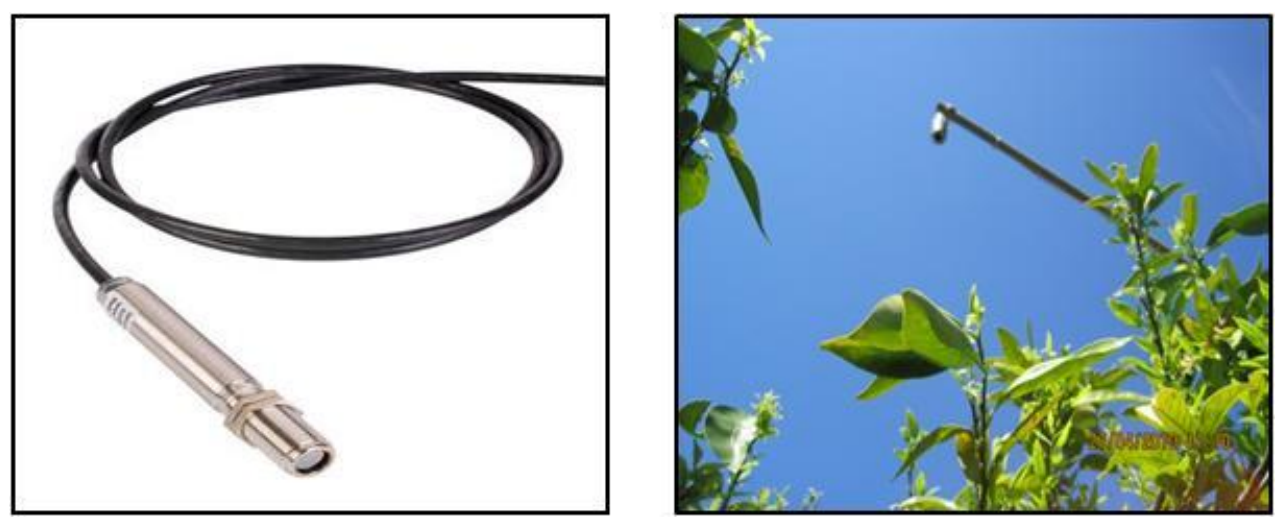

Figure 11 Infrared thermometer sensor employed in the 'Clementina de Nules' grove for the canopy temperature measurements.

Apart from continuous $\mathrm{T}_{\mathrm{c}}$ measurements with IRTs, $\mathrm{T}_{\mathrm{c}}$ was also measured periodically in trees from all treatments with the infrared thermal camera described in the experiment 4 (section 2.5.3). Images were taken weekly (11 days in total) at solar midday concurrently with $\Psi_{\mathrm{s}}$ and $\mathrm{g}_{\mathrm{s}}$ measurements. All images were taken at $1 \mathrm{~m}$ distance from the sunny side of the trees, thus the thermal field of view was of $0.44 \mathrm{~m}^{2}$. Images were analyzed automatically following the procedure of Jiménez-Bello et al. (2011). 
Materials and Methods

\subsubsection{Plant water status measurements}

$\Psi_{\mathrm{s}}$ was determined by pressure chamber (Model 600 Pressure Chamber, PMS Instrument Company, Albany, USA) in two mature leaves of each tree. $G_{\mathrm{s}}$ was measured with a diffusion porometer (SC-1 porometer, Decagon, WA, USA) in 10 sunny leaves per tree.

\subsubsection{Yield determination}

Fruit from sampled trees were picked on $29^{\text {th }}$ November. Yield from each individual tree was weighed and the number of fruit determined in order to obtain the average fruit weight.

\subsubsection{Data analysis}

Data were analyzed using analysis of variance procedure and means were separated by Dunnett's test and contrast between pair of treatments according to the mixed procedure of SAS (SAS Institute, 1994).

The relative transpiration (RT) derived from the continuous SF measurements was used for the water stress detection. RT was calculated by dividing average daily transpiration of the control trees by that of the RDI trees.

Linear relations between the average value of the different water stress indicators for the period of water restrictions and average fruit weight on a per tree basis were explored. 


\section{Results}


Results

\subsection{Experiment 1}

\subsubsection{Meteorological conditions and irrigation volume applied}

$\mathrm{ET}_{\mathrm{o}}$ registered during the five growing seasons, ranged between 1005 and $1090 \mathrm{~mm}$. 2008 was the rainiest year $(553 \mathrm{~mm})$, while 2011 was the driest one $(363 \mathrm{~mm})$ followed closely by 2009 (Table 4). These two drier seasons, 2009 and 2011, were consequently the seasons when the highest irrigation volumes were applied. The water savings achieved in the RDI-1 treatment respect to the control one for each experimental season were $20,22,8,13$ and $15 \%$, respectively. In the RDI-2 treatment, water savings were $31,24,8,16$ and $18 \%$. Pooled over seasons, average water savings were $15 \%$ in the RDI- 1 treatment and $18 \%$ in the RDI- 2 one.

\subsubsection{Plant water status}

$\Psi_{\mathrm{s}}$ registered in control trees was quite similar during the entire experiment with an average value for the five seasons of $-1.0 \pm 0.12 \mathrm{MPa}$ (Figure 12). As expected, during the water restriction period trees from the moderate treatment (RDI-1) showed $\Psi_{\mathrm{s}}$ values more negative than the control trees with average values of $-1.17,-1.42-1.37,-1.35$ and $-1.42 \mathrm{MPa}$ for each experimental season. The threshold value of -1.3 to $-1.5 \mathrm{MPa}$ was exceeded in some occasions, particularly during the first experimental season in DOY 240, characterized by a very high evaporative demand and DOY 254, when no irrigation occurred in all treatments due to a failure of the irrigation system supply. The severe treatment (RDI-2) showed the lowest $\Psi_{\mathrm{s}}$ values, which, on average during the water restriction period for 
Results

each season were $-1.43,-1.69-1.49-1.45$ and $-1.48 \mathrm{MPa}$. Thus, although on a seasonal basis there were only small differences in water application between the RDI-1 and RDI-2 treatments (Table 4), during the restriction period the RDI-2 treatment definitively suffered a more severe water stress (Figure 12).

\subsubsection{Yield and water use efficiency}

The effects of RDI on yield and fruit size varied among seasons. Thus, in 2007 only the RDI-2 treatment, where the seasonal water restriction amounted to $31 \%$, reduced yield and fruit size respect to control and also respect to RDI-1, which had water saving of $20 \%$ (Table 4). In 2008, both RDI levels significantly reduced yield and fruit size compared to the control. This was so despite the fact that the reductions in water applications were similar to those of the previous year (22\% and $24 \%)$. This effect was reflected on the fruit diameter distribution by commercial categories (Figure 13), showing a higher percentage of small fruit in the RDI treatments. In 2009, when the water restriction was milder for both RDI levels (8\%), there were no differences in yield and fruit size respect to the control.

In 2010 and 2011, despite the fact that there were no differences between treatments in yield, in both seasons fruit size was significantly lower in the RDI-2 treatment than in the control.

Pooled over seasons there were no significant differences between the control and RDI-1 treatment (5\% less in yield in RDI-1). RDI-2 treatment, however, showed a significant reduction of about $12 \%$ in yield and about $7 \%$ in fresh fruit weight with respect to the control (Table 8). 
Results
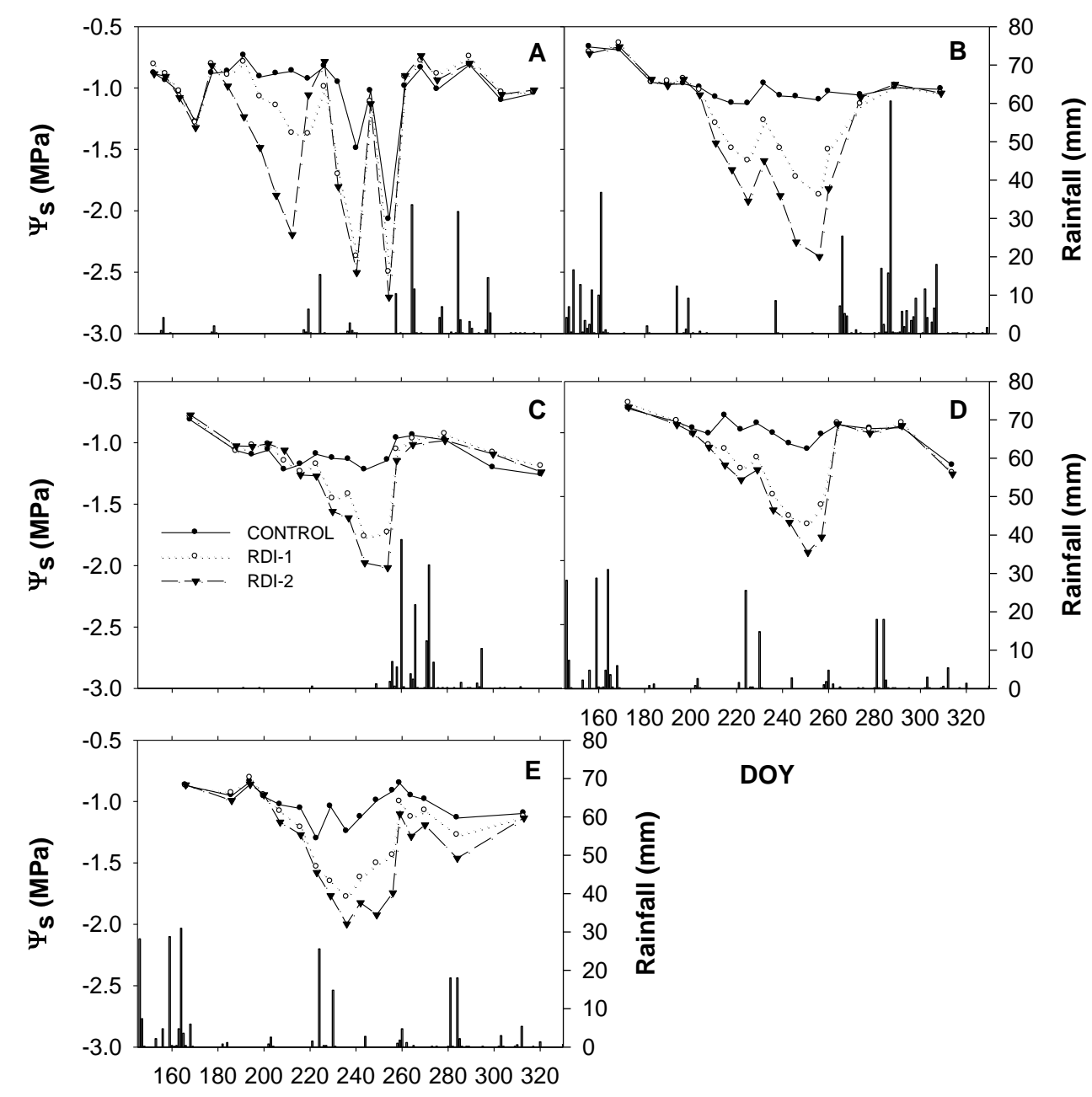

DOY

Figure 12 Seasonal variation of midday stem water potential $\left(\Psi_{\mathrm{s}}\right)$ during 2007 (A), 2008 (B), 2009 (C), 2010 (D) and 2011 (E) in the 'Clementina de Nules' grove. Rainfall events are shown as vertical bars originating from the $\mathrm{x}$ axis. 
Results
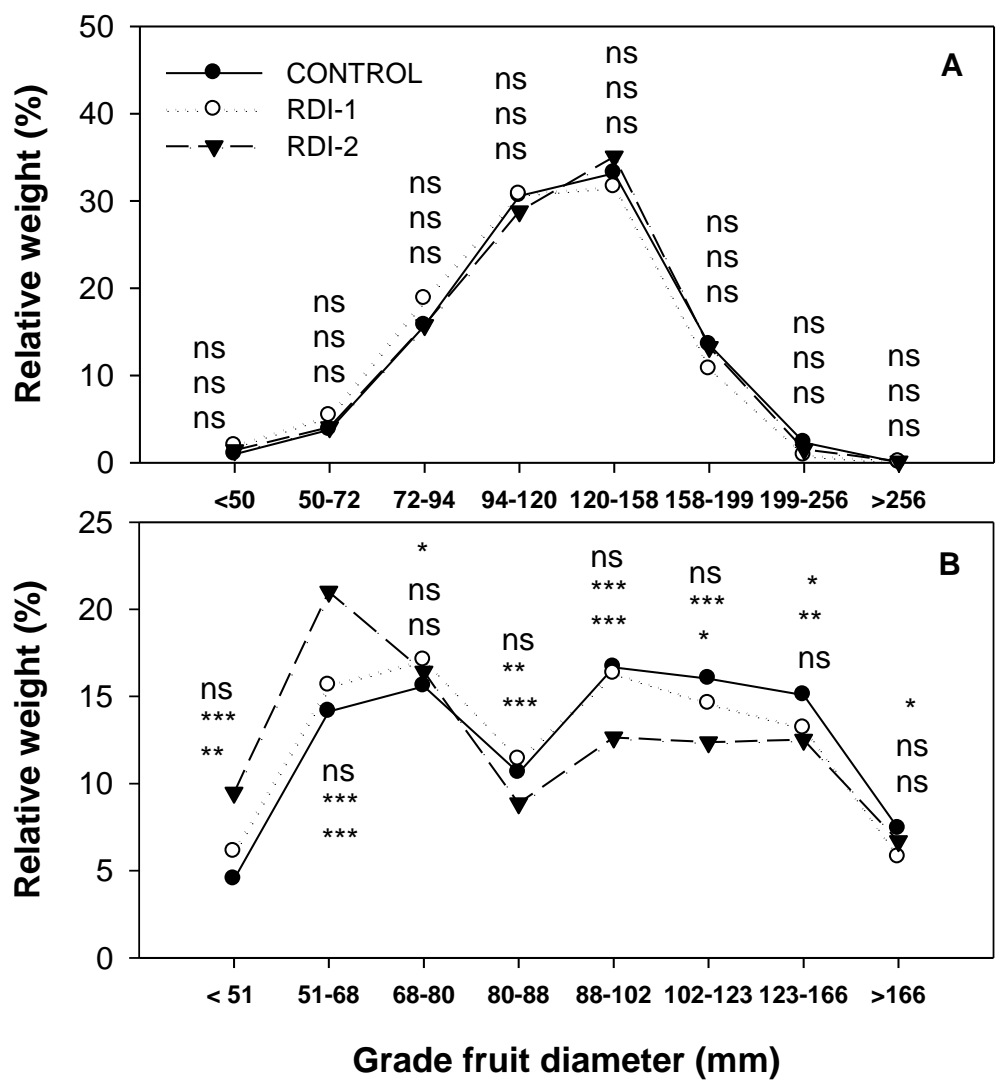

Figure 13 Effect of deficit irrigation on Clementine fruit diameter distribution in commercial categories in 2007 (A) and 2008 (B). ***, **, * and ns, denote significant differences at $\mathrm{P}<0.001,0.01,0.05$, and non significant differences respectively, between factors effect from ANOVA. For each category, the top asterisks or n.s. indicates differences between control and RDC-1, the middle ones between control and RDC- 2 and the bottom one between RDC- 1 and RDC-2. 
Results

Table 8 Effect of deficit irrigation on fruit number per tree, yield and fruit fresh weight at harvest in the 'Clementina de Nules' grove. Different letters within rows denote significant differences at $\mathrm{P}<0.05$ between treatments.

\begin{tabular}{cccll}
\hline \multirow{2}{*}{$\mathbf{N}^{\mathbf{0}}$ fruit per tree } & Year & Control & RDI-1 & RDI-2 \\
& 2007 & 696 & 737 & 485 \\
2008 & 1022 & 826 & 777 \\
2009 & $1271 \mathrm{a}$ & $1367 \mathrm{ab}$ & $1437 \mathrm{~b}$ \\
& 2010 & 945 & 956 & 1016 \\
& 2011 & $1251 \mathrm{a}$ & $1463 \mathrm{ab}$ & $1598 \mathrm{~b}$ \\
& $2007-2011$ & 1075 & 1057 & 1048 \\
Yield (t ha $\left.\mathbf{~}^{-1}\right)$ & 2007 & $30.3 \mathrm{ab}$ & $31.5 \mathrm{a}$ & $27.2 \mathrm{~b}$ \\
& 2008 & $35.7 \mathrm{a}$ & $27.8 \mathrm{~b}$ & $24.3 \mathrm{~b}$ \\
& 2009 & 63.1 & 61.9 & 61.3 \\
& 2010 & 37.2 & 33.4 & 32.8 \\
& 2011 & 52.8 & 51.3 & 50.5 \\
& $2007-2011$ & $43.4 \mathrm{a}$ & $41.4 \mathrm{ab}$ & $38.4 \mathrm{~b}$ \\
& 2007 & $119.0 \mathrm{a}$ & $115.0 \mathrm{a}$ & $106.0 \mathrm{~b}$ \\
& 2008 & $89.6 \mathrm{a}$ & $83.2 \mathrm{~b}$ & $77.1 \mathrm{c}$ \\
& 2009 & 103.3 & 112.0 & 108.3 \\
& 2010 & $90.7 \mathrm{a}$ & $85.6 \mathrm{ab}$ & $81.9 \mathrm{~b}$ \\
2011 & $90.6 \mathrm{a}$ & $88.0 \mathrm{ab}$ & $83.7 \mathrm{~b}$ \\
& $2007-2011$ & $98.5 \mathrm{a}$ & $95.7 \mathrm{ab}$ & $92.1 \mathrm{~b}$ \\
\hline
\end{tabular}

There were significant correlations between the average fruit weight and both $S_{\psi}$ and number of fruit per tree (Figure 14). The regression analysis showed that $S_{\psi}$ explained about $40 \%$ of the observed variability in fruit 
Results

weight while the number of fruit explained the $29 \%$. The coefficient of determination from the multiple regressions was highly significant.

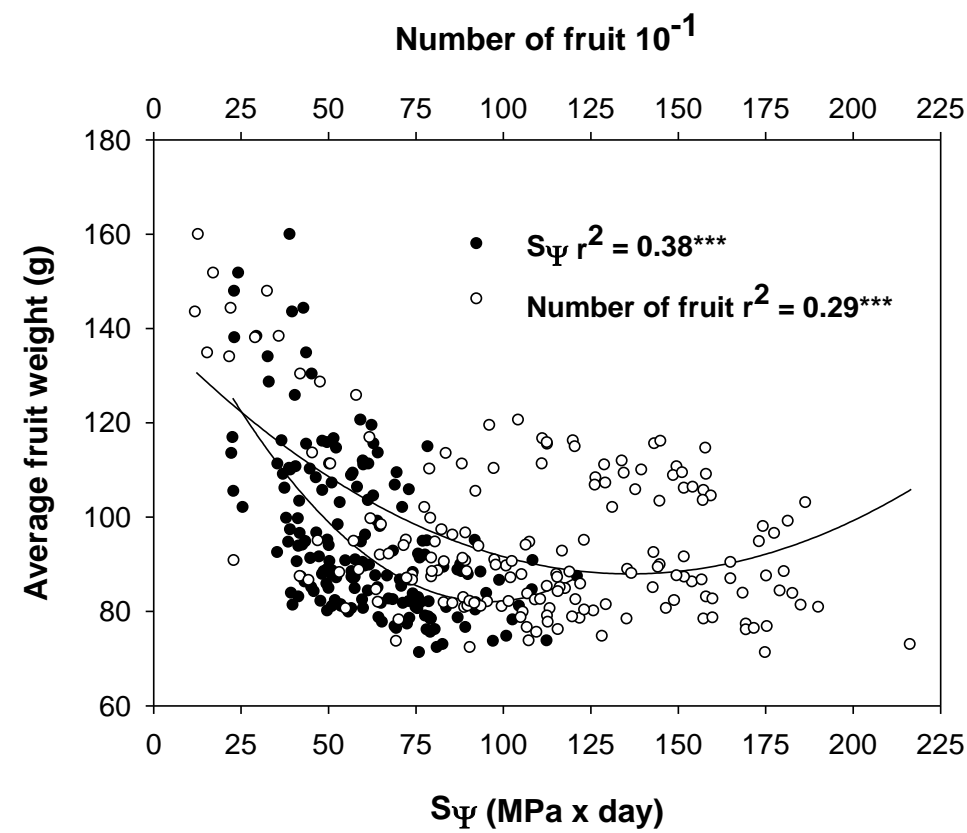

Figure 14 Relationships among the average fruit weight, water stress integral $\left(S_{\psi}\right)$ and number of fruit per tree of 'Clementina de Nules'. The equation obtained from the analysis of multiple regressions was: $\mathrm{y}=139.5-0.47 \mathrm{~S}_{\psi}-$ $0.15 \mathrm{Nf}, \mathrm{r}^{2}=0.45^{* * *}$. Each value is a single measurement per tree $(\mathrm{n}=174)$.

When RDI treatments impaired yield, there was a trend to lower water use efficiency in the RDI trees with respect to the control ones. This trend, however, was statistically significant only in the more severe RDI treatment in 2008 (Table 9). 
Results

Table 9 Effect of deficit irrigation on water use efficiency (WUE) in the 'Clementina de Nules' grove. Different letters within rows denote significant differences at $\mathrm{P}<0.05$ between treatments.

\begin{tabular}{ccccc}
\hline & Year & Control & RDI-1 & RDI-2 \\
WUE $^{\mathbf{1}}\left(\mathbf{k g ~ m}^{-3}\right)$ & 2007 & $5.04 \mathrm{ab}$ & $5.32 \mathrm{a}$ & $3.92 \mathrm{~b}$ \\
2008 & $3.98 \mathrm{a}$ & $3.39 \mathrm{~b}$ & $3.00 \mathrm{~b}$ \\
2009 & 6.57 & 7.35 & 7.28 \\
2010 & 3.91 & 3.74 & 3.72 \\
2011 & 6.57 & 6.95 & 7.23 \\
& $2007-2011$ & 5.21 & 5.35 & 5.03 \\
\hline
\end{tabular}

${ }^{\mathrm{T}}$ Annual rainfall included (average for the five years $448 \mathrm{~mm}$ )

\subsubsection{Fruit quality}

At harvest deficit irrigation significantly increased fruit TSS in every season (Table 10). This effect was higher in the treatment with the highest water restrictions (RDI-2) and especially in 2008, year in which the restriction period lasted longer. TA behavior was similar to TSS. The highest TA values were obtained in the RDI treatments except in 2009, when there were no differences between treatments (Table 10). These effects of RDI on fruit composition were also observed in the post-harvest samples that were maintained during 22 days in cold storage.

\subsubsection{Trunk growth}

Trunk growth was affected by deficit irrigation. RDI trees showed a reduction in the relative trunk growth respect to control trees, although the 
Results

differences were only statistically significant in the first experimental season (Table 11). Over the five years of experiment, the accumulated relative trunk growth was $38.0 \%, 30.6 \%$ and $30.6 \%$ for the control, RDI-1 and RDI2 treatment, respectively.

Table 10 Effect of deficit irrigation on fruit quality at harvest and after a period of 22 days of cold storage in the 'Clementina de Nules' grove. Different letters within rows denote significant differences at $\mathrm{P}<0.05$ between treatments.

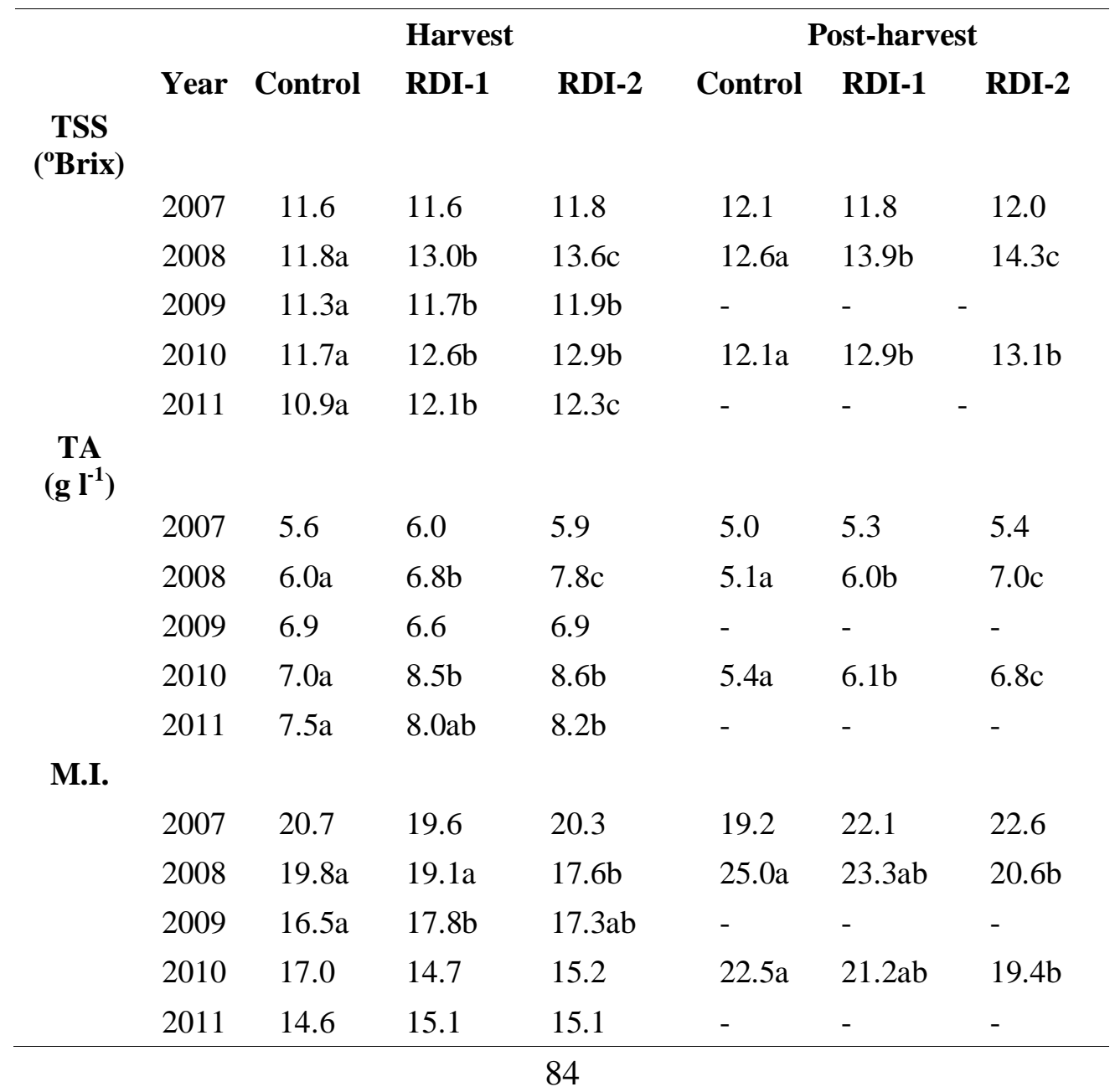


Results

Pruning weights were lower in RDI trees than in the control ones every year except 2007 (Table 11). On average for the experiment both RDI treatments reduced significantly about $19 \%$ the pruning weights respect to the control trees.

Table 11 Effect of deficit irrigation on relative trunk growth in the 'Clementina de Nules' grove. Different letters within rows denote significant differences at $\mathrm{P}<0.05$ between treatments.

\section{Year Control RDI-1 RDI-2}

\section{Relative trunk growth $(\%)$}

$\begin{array}{clll}2007 & 10.7 \mathrm{a} & 9.1 \mathrm{~b} & 9.0 \mathrm{~b} \\ 2008 & 8.6 & 7.8 & 7.2 \\ 2009 & 3.8 & 3.2 & 3.7 \\ 2010 & 4.0 & 3.5 & 3.5 \\ 2011 & 3.4 & 3.0 & 2.9 \\ 2007-2011 & 38.0 \mathrm{a} & 30.6 \mathrm{~b} & 30.6 \mathrm{~b}\end{array}$

Pruning weights $\left(\mathrm{kg} \mathrm{tree}^{-1}\right)$

$\begin{array}{cccl}2007 & 11.0 & 10.9 & 10.2 \\ 2008 & 26.8 \mathrm{a} & 18.8 \mathrm{~b} & 22.6 \mathrm{ab} \\ 2009 & 17.8 \mathrm{a} & 14.0 \mathrm{~b} & 13.6 \mathrm{~b} \\ 2010 & 21.8 \mathrm{a} & 16.7 \mathrm{~b} & 16.8 \mathrm{~b} \\ 2011 & 18.5 \mathrm{a} & 15.4 \mathrm{~b} & 13.0 \mathrm{c} \\ 2007-2011 & 19.4 \mathrm{a} & 15.3 \mathrm{~b} & 15.8 \mathrm{~b}\end{array}$

\subsubsection{Economic return and water productivity}

The moderate RDI level (RDI-1) only reduced significantly the economic return in the second experimental season (Table 12). The more 
severe plant water stress suffered in the RDI-2 treatment, however, resulted in a significant lower economic return every year but 2009. Pooled over seasons, only in this severe RDI treatment the economic return was significantly lower $(16 \%)$ than in control trees.

Water productivity obtained in RDI trees was similar to that in control ones with the exception of 2008 season, in which water productivity was significantly reduced in the RDI-2 treatment (Table 12).

Table 12 Effect of deficit irrigation on economic return and water productivity in the 'Clementina de Nules' grove. Different letters within rows denote significant differences at $\mathrm{P}<0.05$ between treatments.

\begin{tabular}{cccll}
\hline Economic return $\left(€\right.$ tree $\left.^{-\mathbf{1}}\right)$ & Year & Control & RDI-1 & RDI-2 \\
& 2007 & $10.1 \mathrm{a}$ & $9.0 \mathrm{ab}$ & $7.1 \mathrm{~b}$ \\
& 2008 & $11.9 \mathrm{a}$ & $9.2 \mathrm{~b}$ & $7.1 \mathrm{~b}$ \\
& 2009 & 31.7 & 32.6 & 31.5 \\
& 2010 & $7.2 \mathrm{a}$ & $6.3 \mathrm{ab}$ & $5.4 \mathrm{~b}$ \\
& 2011 & $10.3 \mathrm{a}$ & $9.3 \mathrm{ab}$ & $8.4 \mathrm{~b}$ \\
Water productivity $^{-\mathbf{1}}\left({\left.\boldsymbol{\epsilon ~} \mathbf{~ m}^{-\mathbf{3}}\right)}^{2007-2011}\right.$ & $14.2 \mathrm{a}$ & $13.3 \mathrm{ab}$ & $11.9 \mathrm{~b}$ \\
& 2007 & $0.64 \mathrm{a}$ & $0.61 \mathrm{a}$ & $0.50 \mathrm{~b}$ \\
& 2008 & $0.55 \mathrm{a}$ & $0.46 \mathrm{~b}$ & $0.36 \mathrm{c}$ \\
& 2009 & 1.49 & 1.62 & 1.56 \\
& 2010 & $0.32 \mathrm{a}$ & $0.29 \mathrm{ab}$ & $0.26 \mathrm{~b}$ \\
& 2011 & 0.52 & 0.55 & 0.53 \\
& $2007-2011$ & 0.72 & 0.72 & 0.66 \\
\hline
\end{tabular}

${ }^{1}$ Annual rainfall included (average for the five years $448 \mathrm{~mm}$ ) 
Results

\subsection{Experiment 2}

\subsubsection{Meteorological conditions and irrigation volume applied}

$\mathrm{ET}_{\mathrm{o}}$ registered during the four growing seasons, ranged between 1143 and $1341 \mathrm{~mm}$ (Table 6). Year 2008 was the rainiest with $614 \mathrm{~mm}$ of seasonal precipitation, while 2009 was the driest with $342 \mathrm{~mm}$. The air temperature and air vapor pressure deficit for each experimental season during the RDI period (July, August and September) are shown in figure 15.

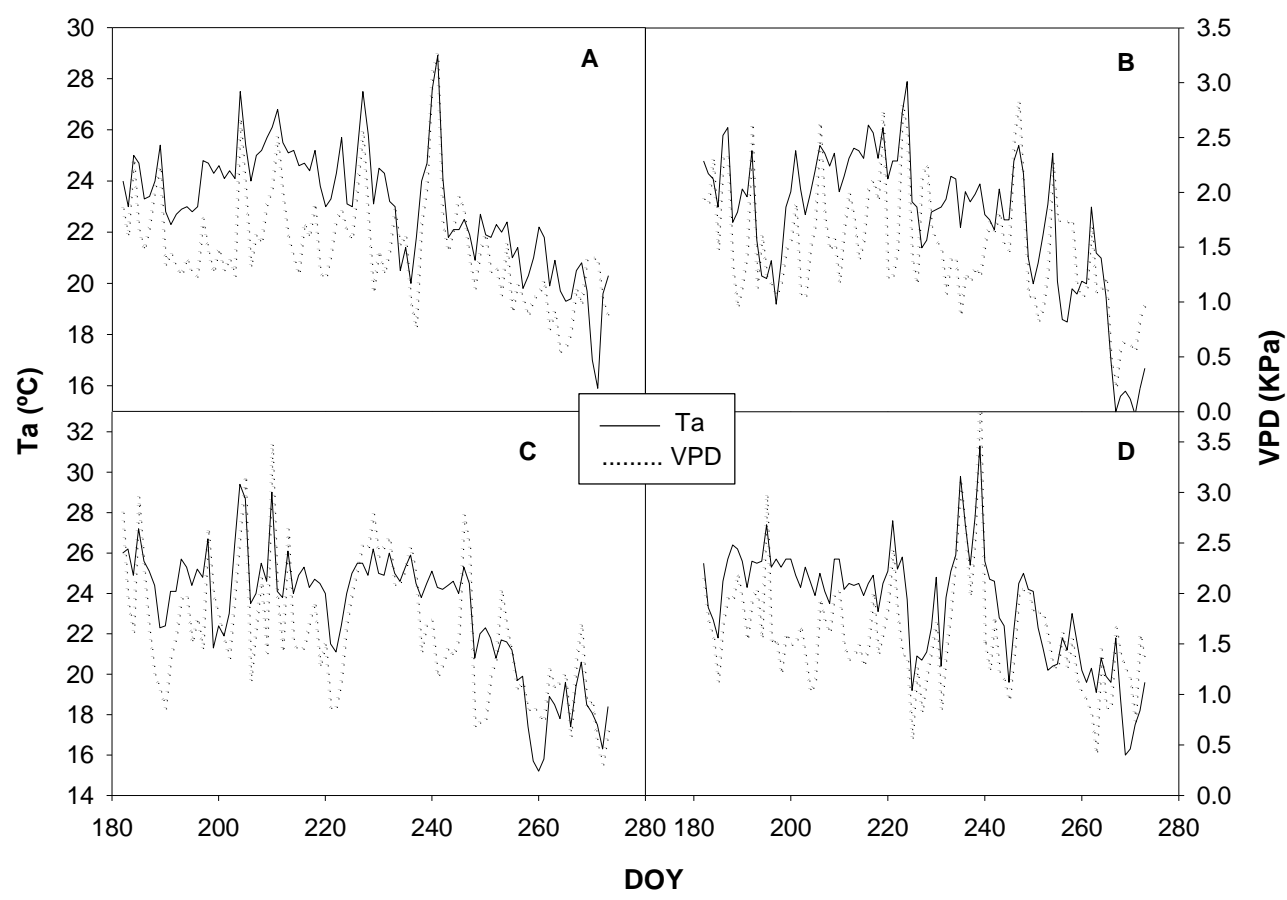

Figure 15 Evolution of air temperature $\left(\mathrm{T}_{\mathrm{a}}\right)$ and air vapor pressure deficit (VPD) during the months of water restrictions for 2007 (A), 2008 (B), 2009 (C) and 2010 (D) in the Navel Lane Late grove. 
Results

The water savings achieved in the RDI treatments for each of the four years of study were, respectively, 30, 18, 19 and 12\% in the RDI-1 and $38,19,22$ and $16 \%$ in the RDI-2.

\subsubsection{Plant water status}

$\Psi_{\mathrm{s}}$ values registered in the control treatment were quite similar during the four years of study with an average value pooled over seasons of $-0.91 \pm 0.24 \mathrm{MPa}$ (Figure 16). During the period of water restrictions, trees from both RDI treatments showed $\Psi_{\mathrm{s}}$ values more negative than the control ones. For the RDI-1 treatment, average $\Psi_{\mathrm{s}}$ values were of $-1.05,-1.45,-1.22$ and $-1.13 \mathrm{MPa}$ for each experimental season, respectively, with the corresponding $\mathrm{S}_{\psi}$ values of $66.1,88.0,64.2$ and $46.7 \mathrm{MPa}$ *day. The RDI-2 trees, with more severe water restrictions, showed the lowest $\Psi_{\mathrm{s}}$ values. On average for the complete water restriction periods of each season these values were $-1.17,-1.54,-1.33$ and -1.35 , respectively. The $S_{\psi}$ values reached for each season in this case were 75.8, 94.3, 78.9 and 59.3 $\mathrm{MPa}$ *day, respectively.

There was some general variation in plant water status among seasons (Figure 16). The lowest $\Psi_{\mathrm{s}}$ values were in general recorded in 2008 and even the control trees reached $\Psi_{\mathrm{s}}$ values near -1.5 $\mathrm{MPa}$ due to some failures in the irrigation system supply that prevented the irrigation during a couple of days. 
Results

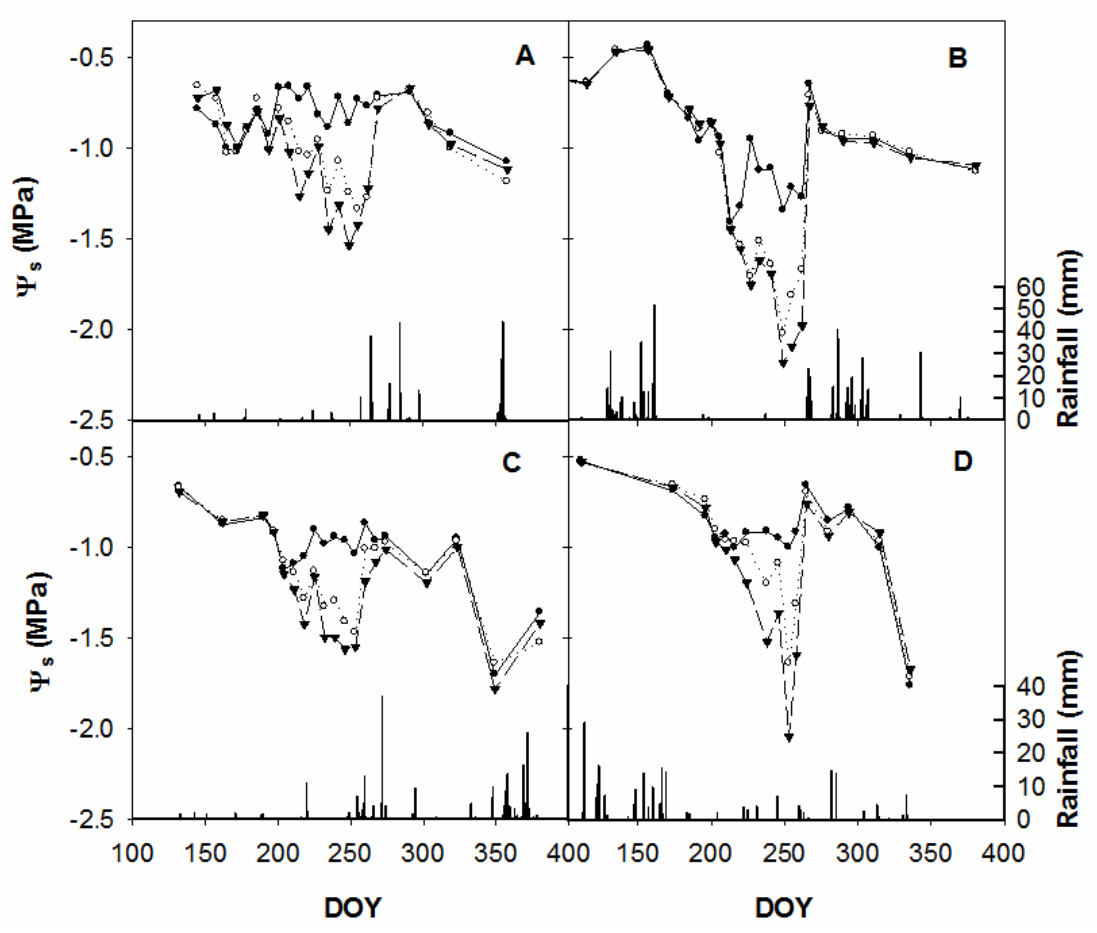

Figure 16 Seasonal variations of midday stem water potential $\left(\Psi_{\mathrm{s}}\right)$ during 2007 (A), 2008 (B), 2009 (C) and 2010 (D) in Navel Lane Late. Rainfall events are shown as vertical bars originating from the $\mathrm{x}$ axis.

\subsubsection{Yield and water use efficiency}

Yield and its components were markedly different among years and the effect of the "year" from ANOVA was highly significant $(\mathrm{P}<0.01)$.

Similarly, the effects of the RDI treatments on yield varied among seasons. In 2007 and 2008, both RDI treatments reduced significantly yield and fruit weight respect to the control (Table 13). Contrarily, in 2009, water 
Results

savings of $19 \%$ in the RDI-1 treatment, did not reduce yield nor fruit weight in this treatment. However, $22 \%$ of water savings in the RDI-2 treatment did reduce significantly both parameters. In the last experimental season, water savings of $12 \%$ and $16 \%$ in the RDI- 1 and RDI- 2 treatments, respectively, did not significantly reduce yield respect to the control although the fruit weight was negatively affected (Table 13). RDI treatments shifted the fruit size distribution in all seasons towards smaller fruit size (Figure 17).

Table 13 Effect of deficit irrigation on fruit number per tree, yield and fruit fresh weight at harvest in Navel Lane Late. Different letters within rows denote significant differences at $\mathrm{P}<0.05$ between treatments.

\begin{tabular}{ccccc}
\hline \multirow{2}{*}{$\mathbf{N}^{\mathbf{0}}$ fruit per tree } & Year & Control & RDI-1 & RDI-2 \\
& 2007 & 287 & 281 & 262 \\
& 2008 & 568 & 535 & 542 \\
& 2009 & 439 & 471 & 452 \\
Yield (t ha $\left.{ }^{-1}\right)$ & 2010 & 462 & 533 & 510 \\
& $2007-2010$ & 442 & 454 & 444 \\
& 2007 & $30.9 \mathrm{a}$ & $26.2 \mathrm{~b}$ & $25.2 \mathrm{~b}$ \\
& 2008 & $47.0 \mathrm{a}$ & $36.3 \mathrm{~b}$ & $35.4 \mathrm{~b}$ \\
& 2009 & $37.9 \mathrm{a}$ & $37.1 \mathrm{ab}$ & $34.6 \mathrm{~b}$ \\
& 2010 & 44.5 & 42.2 & 39.0 \\
& $2007-2010$ & $40.0 \mathrm{a}$ & $36.1 \mathrm{ab}$ & $33.9 \mathrm{~b}$ \\
& 2007 & $255 \mathrm{a}$ & $234 \mathrm{~b}$ & $230 \mathrm{~b}$ \\
& 2008 & $214 \mathrm{a}$ & $184 \mathrm{~b}$ & $178 \mathrm{~b}$ \\
& 2009 & $253 \mathrm{a}$ & $239 \mathrm{ab}$ & $223 \mathrm{~b}$ \\
& 2010 & $261 \mathrm{a}$ & $234 \mathrm{~b}$ & $225 \mathrm{c}$ \\
& $2007-2010$ & $246 \mathrm{a}$ & $223 \mathrm{~b}$ & $214 \mathrm{~b}$ \\
\hline
\end{tabular}




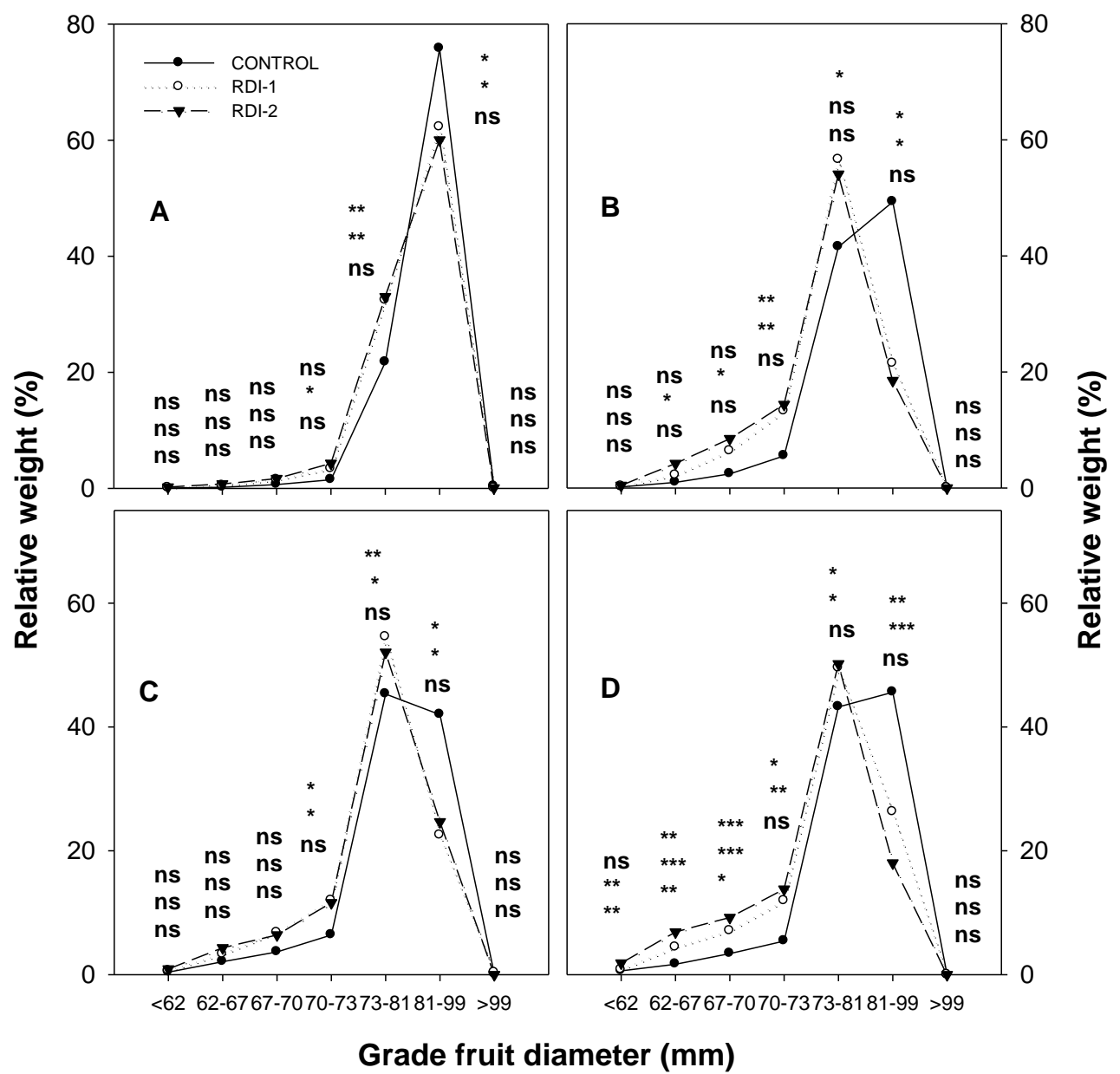

Figure 17 Effect of deficit irrigation on fruit diameter distribution in commercial categories for 2007 (A), 2008 (B), 2009 (C) and 2010 (D) in Navel Lane Late. $* * *, * * *$ and $\mathrm{ns}$, denote significant differences at $\mathrm{P}<0.001,0.01,0.05$, and non significant differences respectively, by Dunnett's test. For each category, the top asterisks or n.s. indicates differences between Control and RDI-1, the middle ones between Control and RDI-2 and the bottom one between RDI- 1 and RDC-2. 
Results

Pooled over seasons, fruit weight was reduced in both RDI levels respect to the control (9\% in RDI-1 and 13\% in RDI-2). Although this fruit weight reduction was not sufficient to significantly impair yield in the RDI1 treatment, it did reduce yield by a significant $15 \%$ in the RDI- 2 treatment compared to the control one (Table 13).

As observed in the 'Clementina de Nules' experiment, there were significant correlations between the average fruit weight and both $S_{\psi}$ and number of fruit per tree (Figure 18). The regression analysis showed that $S_{\psi}$ explained $34 \%$ of the observed variability in fruit weight while the number of fruit explained the $24 \%$. The coefficient of determination from the multiple regressions was of 0.52 , value statistically significant.

Table 14 Effect of deficit irrigation on water use efficiency (WUE) in Navel Lane Late. Within rows, different letters mean significant differences at $\mathrm{P}<0.05$ with respect to control by Dunnett's test.

\begin{tabular}{ccccc}
\hline WUE $^{\mathbf{1}}\left(\mathrm{kg} \mathrm{m}^{-3}\right)$ & Year & Control & RDI-1 & RDI-2 \\
2007 & 3.42 & 3.51 & 3.32 \\
2008 & $4.83 \mathrm{a}$ & $4.14 \mathrm{~b}$ & $3.97 \mathrm{~b}$ \\
2009 & $4.25 \mathrm{~b}$ & $4.68 \mathrm{a}$ & $4.44 \mathrm{ab}$ \\
2010 & 4.51 & 4.57 & 4.32 \\
& $2007-2010$ & 4.25 & 4.23 & 4.01 \\
\hline
\end{tabular}

${ }^{\mathrm{I}}$ Annual rainfall included (average of the five years: $506 \mathrm{~mm}$ )

When the RDI treatments impaired yield, there was a trend to lower water use efficiency in the RDI trees than in control ones. These differences however were only significant in 2008 for both restriction levels and in 
Results

2009 for the RDI-1. Pooled over seasons there were no significant differences in any case (Table 14).

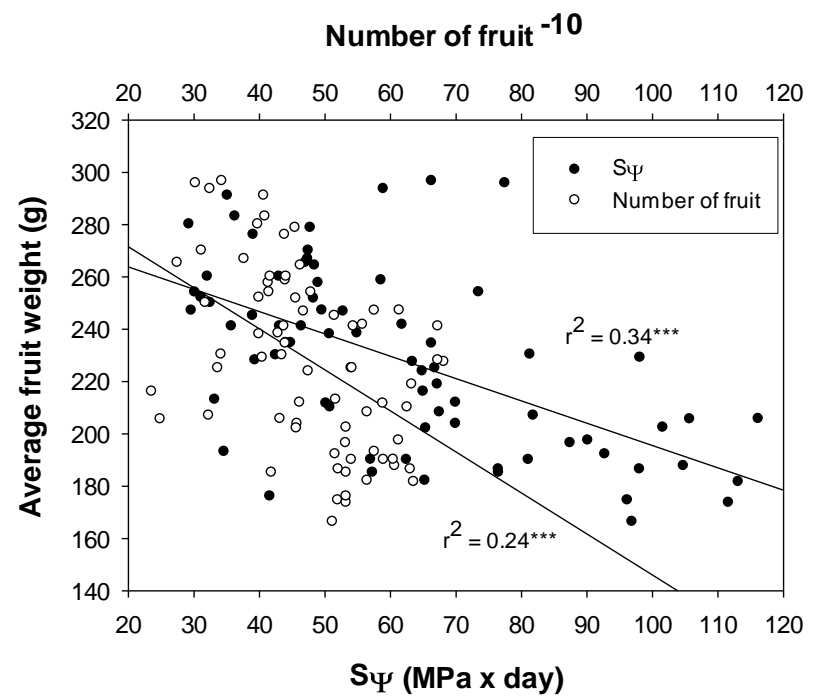

Figure 18 Relationships among the average fruit weight and the water stress integral $\left(S_{\psi}\right)$ and number of fruit per tree in Navel Lane Late. The equation obtained from the analysis of multiple regressions was: $\mathrm{y}=342.5-0.78 \mathrm{~S}_{\psi}-$ $0.14 \mathrm{Nf}, \mathrm{r}^{2}=0.52^{* * *}$. Each value is a single measurement per tree $(\mathrm{n}=72)$. The period length used to calculate the $S_{\psi}$ varied between 56 and 88 days for the different years depending on the duration of the water restriction period.

\subsubsection{Fruit quality}

Fruit quality varied among years with a statistical significant effect $(\mathrm{P}<0.05)$ of the "year" effect from ANOVA. Deficit irrigated treatments increased fruit TSS and TA at harvest every season with significant differences every year except in 2010 (Table 15). This increase was 
Results

generally proportional to the intensity of the water stress applied, showing the RDI-2 treatment the highest values. In season 2009, deficit irrigation led to the highest increase in TSS respect to the control while the largest increase in TA was in 2007, when the RDI period lasted longer.

Table 15 Effect of deficit irrigation on fruit juice total soluble solids (TSS), titratable acidity (TA) and maturity index (MI) at harvest and after a period of 22 days of cold storage in Navel Lane Late. Different letters within rows denote significant differences at $\mathrm{P}<0.05$ between treatments.

\section{Harvest}

Year Control RDI-1 RDI-2 Control RDI-1 RDI-2

TSS ( $\left.{ }^{\circ} \mathrm{Brix}\right)$

$\begin{array}{llllccc}2007 & 11.3 \mathrm{a} & 12.2 \mathrm{~b} & 11.9 \mathrm{ab} & 11.3 \mathrm{a} & 12.2 \mathrm{~b} & 12.3 \mathrm{~b} \\ 2008 & 11.5 \mathrm{a} & 12.3 \mathrm{~b} & 12.3 \mathrm{~b} & 11.8 \mathrm{a} & 12.4 \mathrm{~b} & 12.8 \mathrm{~b} \\ 2009 & 12.2 \mathrm{a} & 13.5 \mathrm{~b} & 13.6 \mathrm{~b} & - & - & - \\ 2010 & 10.9 & 11.2 & 11.6 & 11.1 \mathrm{a} & 11.7 \mathrm{~b} & 12.1 \mathrm{~b}\end{array}$

TA $\left(\mathbf{g ~ l}^{-1}\right)$

$\begin{array}{llllccr}2007 & 8.6 \mathrm{a} & 10.7 \mathrm{~b} & 11.0 \mathrm{~b} & 10.3 \mathrm{a} & 12.4 \mathrm{~b} & 13.2 \mathrm{~b} \\ 2008 & 8.7 \mathrm{a} & 9.9 \mathrm{~b} & 10.2 \mathrm{~b} & 8.7 \mathrm{a} & 9.6 \mathrm{~b} & 9.9 \mathrm{~b} \\ 2009 & 7.5 \mathrm{a} & 9.1 \mathrm{~b} & 9.5 \mathrm{~b} & - & - & - \\ 2010 & 8.3 \mathrm{a} & 8.9 \mathrm{ab} & 9.5 \mathrm{~b} & 9.6 \mathrm{a} & 11.5 \mathrm{~b} & 11.5 \mathrm{~b}\end{array}$

M.I.

$\begin{array}{llllccc}2007 & 13.2 \mathrm{a} & 11.5 \mathrm{~b} & 10.9 \mathrm{~b} & 11.0 & 10.0 & 9.5 \\ 2008 & 13.2 \mathrm{a} & 12.4 \mathrm{~b} & 12.1 \mathrm{~b} & 13.7 \mathrm{a} & 13.0 \mathrm{~b} & 13.1 \mathrm{ab} \\ 2009 & 16.3 \mathrm{a} & 14.9 \mathrm{~b} & 14.2 \mathrm{~b} & - & - & - \\ 2010 & 13.2 \mathrm{a} & 12.7 \mathrm{ab} & 12.2 \mathrm{~b} & 11.6 \mathrm{a} & 10.3 \mathrm{~b} & 10.6 \mathrm{~b}\end{array}$


Results

The maturity index was significantly reduced respect to the control by both RDI treatments every season with the exception of the RDI-1 treatment in 2010. These effects of RDI on fruit composition were also observed in the post-harvest samples that were maintained during 25 days in cold storage (Table 15).

\subsubsection{Trunk growth}

When the experiment started the average value for the trunk perimeter of all the sampling trees was $32.1 \pm 2.5 \mathrm{~cm}$. RDI treatments reduced trunk perimeter growth (Table 16). Over the four years of the experiment the accumulated relative trunk perimeter growth was 39.6, 30.1 and $29.5 \%$ for the control, RDI-1 and RDI-2 treatments, respectively. These differences, however, were not statistically significant $(\mathrm{P}<0.05)$ due to the large variability found in trunk growth within trees $(\mathrm{CV}=30 \%)$.

Table 16 Effect of deficit irrigation on relative trunk perimeter growth in Navel Lane Late. ${ }^{*}$ denote significant differences at $\mathrm{P}<0.05$ with respect to control by Dunnett's test.

\section{Year Control RDI-1 RDI-2}

\section{Relative trunk growth $(\%)$}

$\begin{array}{clll}2007 & 13.1 \mathrm{a} & 9.7 \mathrm{~b} & 11.0 \mathrm{ab} \\ 2008 & 7.1 & 6.0 & 6.2 \\ 2009 & 7.0 & 6.0 & 5.7 \\ 2010 & 6.7 \mathrm{a} & 6.3 \mathrm{ab} & 6.1 \mathrm{~b} \\ 2007-2010 & 39.6 \mathrm{a} & 30.1 \mathrm{~b} & 29.5 \mathrm{~b}\end{array}$


Results

\subsubsection{Economic return and water productivity}

The moderate RDI level (RDI-1) significantly reduced the economic return compared to the control the two first years of experiment (Table 17) when yield was impaired but did not show differences in 2009 and 2010 nor when pooled over the seasons. Nevertheless, the higher plant water stress that occurred in the RDI-2 treatment (Figure 16) resulted in a significantly smaller economic return every year, which on average for the four seasons amounted to $6.3 €$ per tree or $22 \%$ respect to the control (Table 17 ).

Table 17 Effect of deficit irrigation on economic return and water productivity in Navel Lane Late. Different letters within rows denote significant differences at $\mathrm{P}<0.05$ between treatments.

\section{Year Control RDI-1 RDI-2}

Economic return $\left(€\right.$ tree $\left.^{-1}\right)$

$\begin{array}{clll}2007 & 26.1 \mathrm{a} & 22.2 \mathrm{~b} & 21.2 \mathrm{~b} \\ 2008 & 29.5 \mathrm{a} & 21.0 \mathrm{~b} & 20.4 \mathrm{~b} \\ 2009 & 26.2 \mathrm{a} & 24.6 \mathrm{ab} & 23.3 \mathrm{~b} \\ 2010 & 31.6 \mathrm{a} & 28.0 \mathrm{ab} & 24.6 \mathrm{~b} \\ 2007-2010 & 28.4 \mathrm{a} & 24.2 \mathrm{ab} & 22.1 \mathrm{~b}\end{array}$

Water productivity ${ }^{1}\left(€ \mathbf{m}^{-3}\right)$

$\begin{array}{llll}2007 & 1.20 & 1.21 & 1.14 \\ 2008 & 1.28 \mathrm{a} & 0.99 \mathrm{~b} & 0.91 \mathrm{~b} \\ 2009 & 1.25 & 1.29 & 1.22 \\ 2010 & 1.33 \mathrm{a} & 1.26 \mathrm{ab} & 1.14 \mathrm{~b} \\ 2007-2010 & 1.27 & 1.19 & 1.10\end{array}$

${ }^{1}$ Annual rainfall included (average of the five years: $506 \mathrm{~mm}$ ) 
Results

Both RDI treatments showed similar water productivity values than control trees in 2007, 2009 and 2010. In 2008, water productivity was clearly reduced in both RDI treatments although with significant differences only in the RDI-2 treatment (Table 17). The "year" effect was significant $(\mathrm{P}<0.05)$ for both the economic return and the water productivity.

\subsection{Comparison between 'Clementina de Nules' and 'Navel Lane Late' sensitivity to deficit irrigation}

In both species fresh fruit weight was significantly correlated to the average $\Psi_{\mathrm{s}}$ measured during the period of water restrictions, although less tightly in 'Clementina de Nules' than in 'Navel Lane Late'. More importantly, the difference of the slopes of both species (Figure 19) was highly significant $(\mathrm{P}<0.001)$ indicating that 'Navel Lane Late' is more sensitive than 'Clementina de Nules' to deficit irrigation.

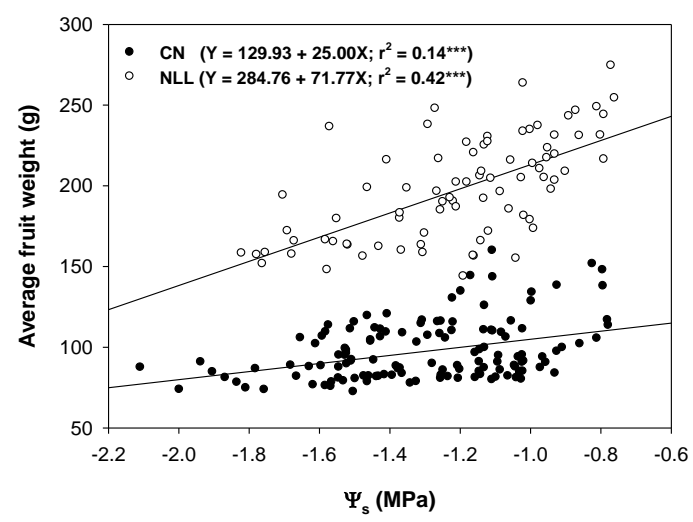

Figure 19 Relationships between stem water potential $\left(\Psi_{\mathrm{s}}\right)$ and average fruit fresh weight at harvest in 'Clementina de Nules' (CN) and 'Navel Lane Late' (NLL). Data from 2007 to 2010 ( $\mathrm{n}=132$ in CN and 82 in NLL). 
Results

Regarding fruit quality, the relationships between TSS and TA with $\Psi_{\mathrm{s}}$ showed that 'Clementina de Nules' and 'Navel Lane Late' had a similar increase in these parameters as $\Psi_{\mathrm{s}}$ decreased (Figure 20A,B). Both species had similar values of TSS which ranged around 11, when $\Psi_{\mathrm{s}}$ was lower than -1 $\mathrm{MPa}$, and around 14 when $\Psi_{\mathrm{s}}$ values were lower than -1.8 MPa. TA, however, was significantly higher in 'Navel Lane Late' than in 'Clementina de Nules'. Due to the differences in TA between species, the maturity index was significantly higher in 'Clementina de Nules' than in 'Navel Lane Late' (Figure 20C). In this case, the slopes also differed significantly $(\mathrm{P}<0.05)$ being the mandarin the species in which the maturity index was more affected by the deficit irrigation imposed.

\subsection{Experiment 3}

\subsubsection{Meteorological conditions and plant water status}

In the mandarin grove, total rainfall and $\mathrm{ET}_{\mathrm{o}}$ registered during the period of water restrictions in 2009 (from $28^{\text {th }}$ of July to $14^{\text {th }}$ of September) were $11.2 \mathrm{~mm}$ and $223 \mathrm{~mm}$, respectively. These values were lower than those registered during the RDI period (from $20^{\text {th }}$ of July to $14^{\text {th }}$ of September) in 2010 (49.4 mm and $251 \mathrm{~mm}$, respectively). The orange grove had a total rainfall during the period of water restrictions of $21.3 \mathrm{~mm}$ and an $\mathrm{ET}_{\mathrm{o}}$ of $290 \mathrm{~mm}$. Daily $\mathrm{ET}_{\mathrm{o}}$ values ranged between 4.5 and $5.7 \mathrm{~mm}$, typical of a Mediterranean climate under coastal conditions. Only during a couple of days in the 'Navel Lane Late' experiment, $\mathrm{ET}_{\mathrm{o}}$ increased to values around $7 \mathrm{~mm}$ (Figure 21). 
Results

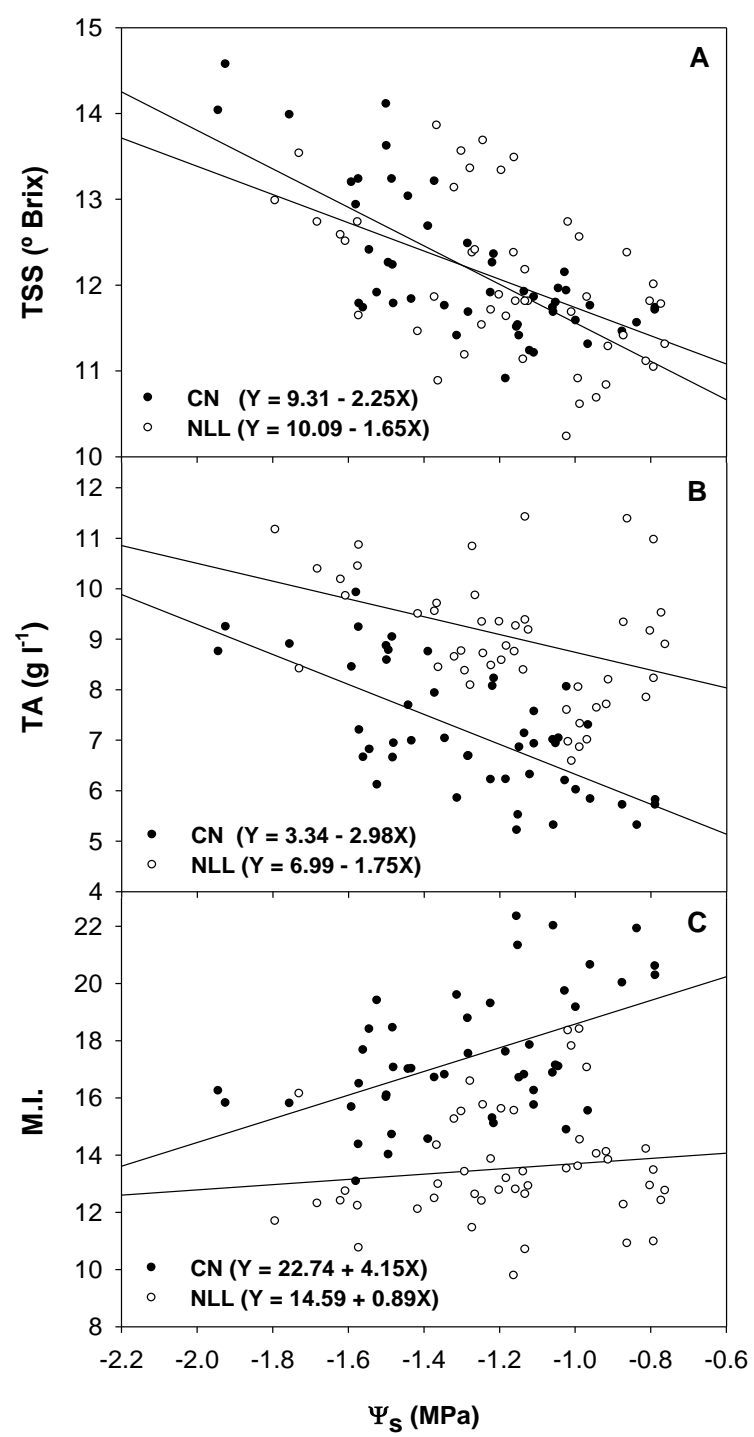

Figure 20 Relationships between total soluble solids (TSS), titratable acidity (TA) and maturity index (M.I.) against averaged stem water potential ( $\left.\Psi_{\mathrm{s}}\right)$ during the period of water restrictions. 
Results

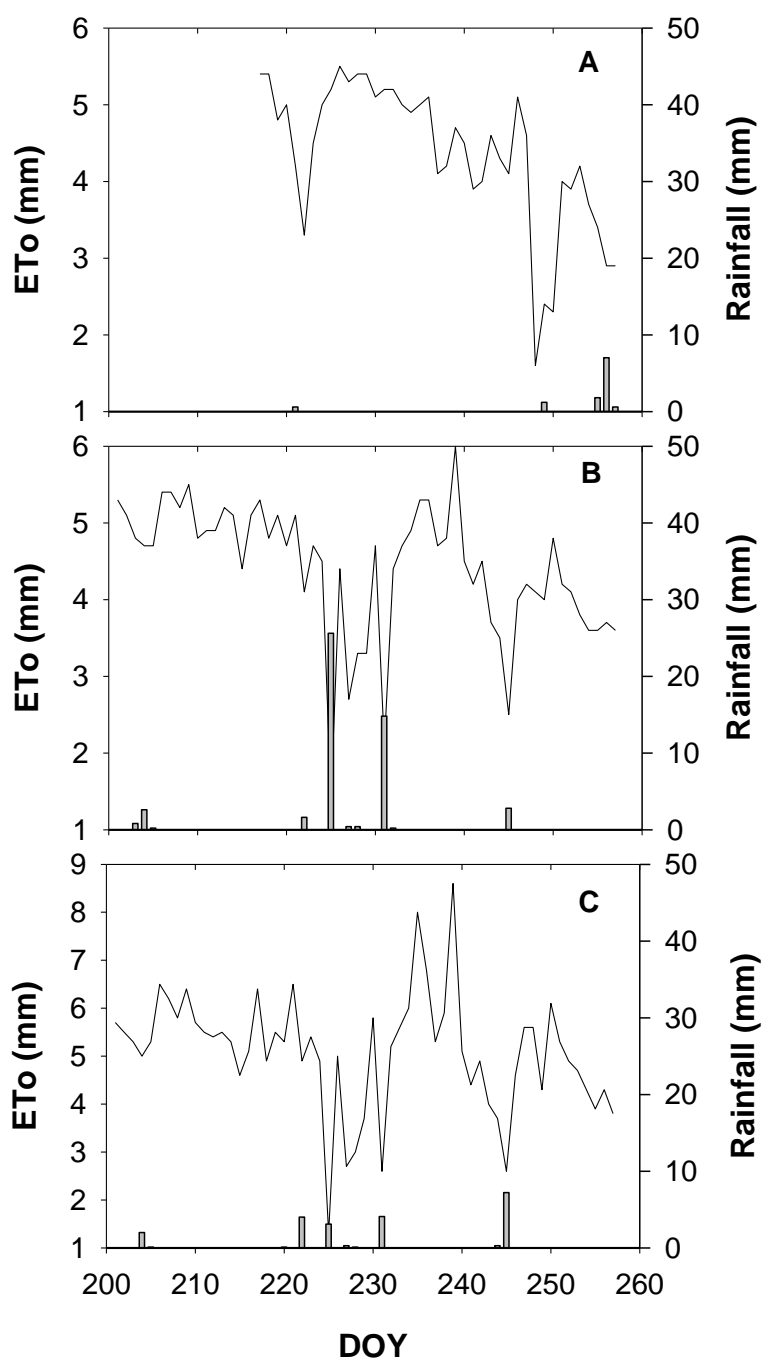

Figure 21 Rainfall and reference evapotranspiration $\left(\mathrm{ET}_{\mathrm{o}}\right)$ registered during the period of water restrictions in the 'Clementina de Nules' orchard, 2009 (A) and 2010 (B) season, and in the 'Navel Lane Late' one (C). 
Results

For the period of water restrictions, average $\Psi_{\mathrm{s}}$ values for the 'Clementina de Nules' and 'Navel Lane Late' control trees were $-1.1 \pm 0.2$ MPa. 'Clementina de Nules' RDI trees, however, had an average $\Psi_{\mathrm{s}}$ value of $-1.5 \pm 0.4 \mathrm{MPa}$ while in 'Navel Lane Late' RDI trees this value was of $1.4 \pm 0.5 \mathrm{MPa}$, reaching a minimum value of $-2.4 \mathrm{MPa}$ (Figure 22 and 23).

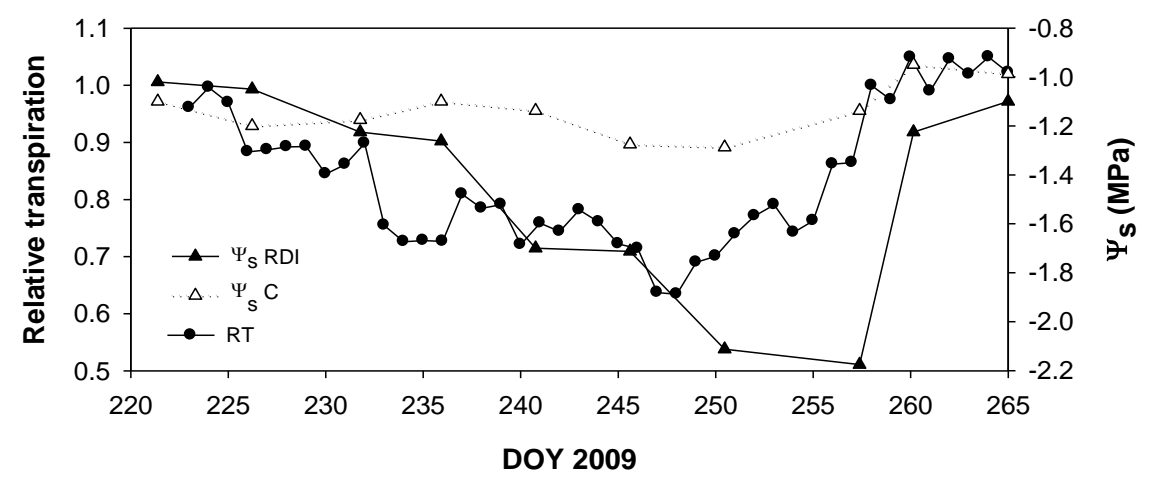

Figure 22 Evolution of stem water potential $\left(\Psi_{\mathrm{s}}\right)$ and relative transpiration (SF (RDI/C)) in 'Clementina de Nules' trees instrumented with the type2 gauges during the RDI period of 2009.

\subsubsection{Sap flow measurements for plant transpiration estimations}

Diurnal pattern of sap flow was characterized by a quick increase from sunrise, reaching maximum rates from 12:00 to 15:00 (solar time) and declining until late in the afternoon. In the RDI trees sap flow was also approximately symmetrical in relation to solar noon (Figure 24). 


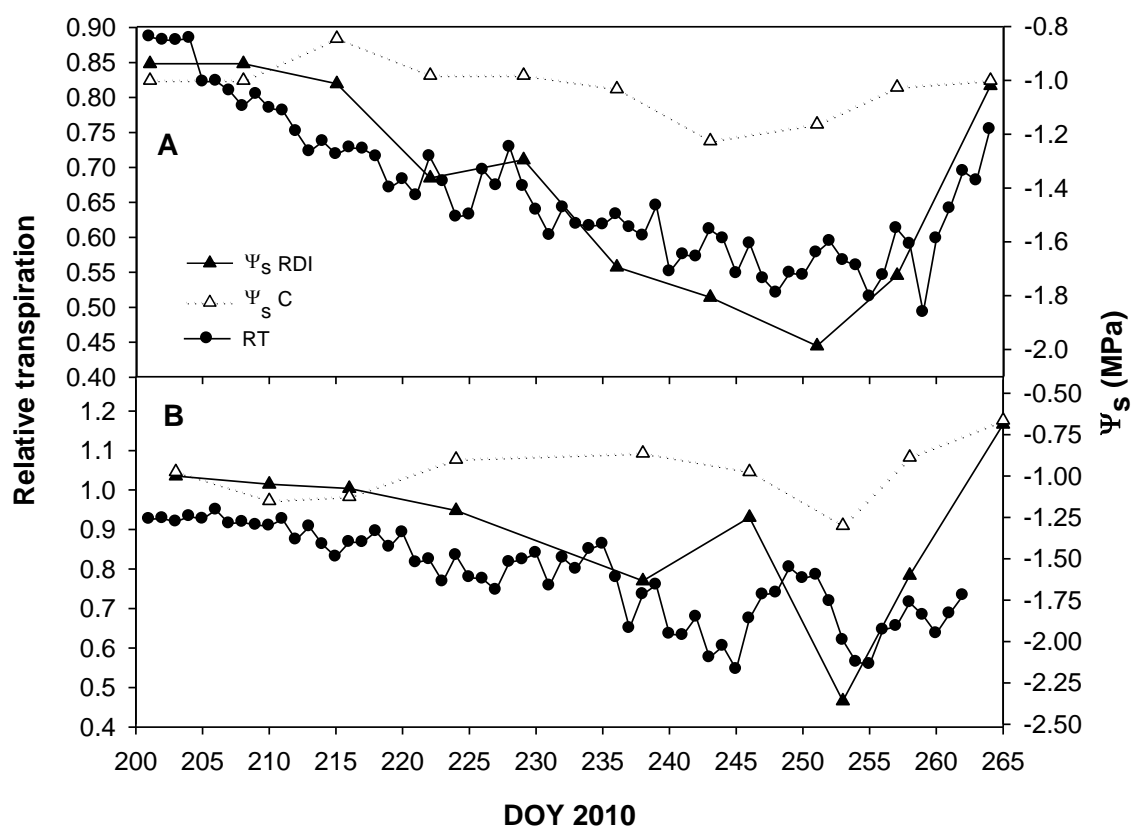

Figure 23 Evolution of stem water potential $\left(\Psi_{\mathrm{s}}\right)$ and relative transpiration (SF (RDI/C)) for 'Clementina de Nules' trees instrumented with type2 gauges (A) and 'Navel Lane Late' trees (B) during the RDI period of 2010.

During the period of water restrictions control trees had higher transpiration rates than the water-stressed ones.

Absolute daily sap flow values registered in 'Clementina de Nules' differed between type 1 and type 2 gauges (Table 18). Type 1 gauges gave values 1.4 to 2.4 higher than type 2 ones. Thus, the maximum transpiration (Tm) obtained in control trees, calculated by dividing daily sap flow values by $\mathrm{ET}_{\mathrm{o}}$, was 0.25 and 0.23 in 2009 and 2010, respectively, for type 1 gauges and 0.16 in both years for type 2 ones. Tm obtained in 'Navel Lane Late' control trees was 0.33 , a higher value than that of 'Clementina de Nules'. 
Results

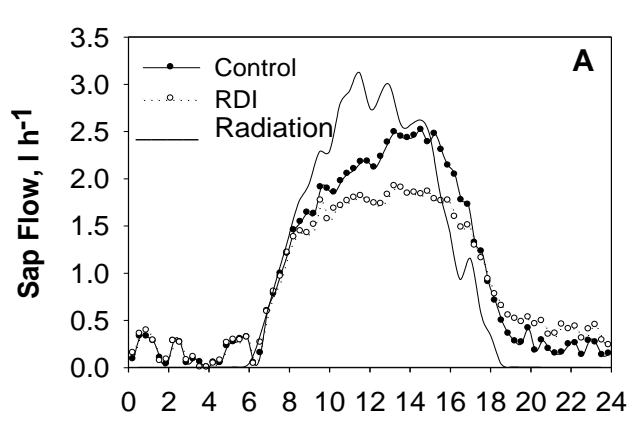

Hour

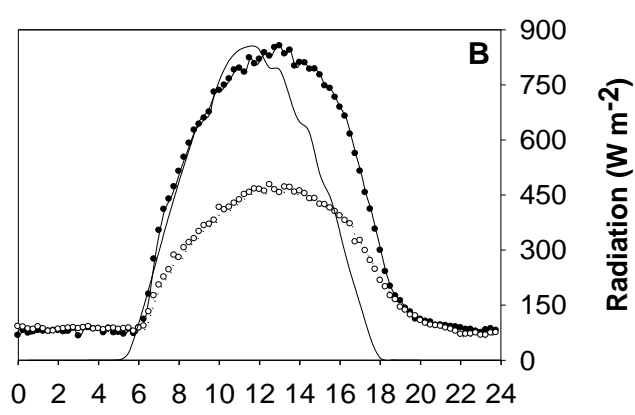

Hour

Figure 24 Radiation and sap flow evolution in a day with a difference of $0.8 \mathrm{MPa}$ in midday stem water potential between control and RDI trees for 'Clementina de Nules' (A; Day 08/09/2010) and 'Navel Lane Late' (B; Day $10 / 09 / 2010)$.

Daily sap flow values for well-watered trees showed a good correlation with $\mathrm{ET}_{0}$, especially in 'Navel Lane Late' (Figure 25). Data was best-fitted by a polynomial curve. The relationship between daily sap flow and average daily air vapor pressure deficit (VPD) also fitted a polynomial curve (results not-shown) but with weaker correlation than with $\mathrm{ET}_{\mathrm{o}}$ ('Clementina de Nules' $r^{2}=0.55^{* * *}$, 'Navel Lane Late' $\left.r^{2}=0.76 * * *\right)$. In addition, Tm in control trees showed a significant negative correlation with VPD (Figure 26).

In 2010, one month after the beginning of the water restrictions, when differences in $\Psi_{\mathrm{s}}$ between control and RDI trees were of $0.7-0.8$ $\mathrm{MPa}$, the decrease in transpiration registered in the less irrigated trees was 
Results

$21 \%$ on average for the two orchards and gauge types. For the whole period of water restrictions, water savings in the Clementine RDI trees were $51 \%$ and this represented a calculated decrease in transpiration for that period of 15 and $25 \%$ for the type 1 and type 2 gauges, respectively. In 'Navel Lane Late', the RDI treatment allowed water savings of $49 \%$ and the transpiration reduction was of $15 \%$, the same as in 'Clementina de Nules' for type 1 gauges.

Table 18 Average daily values of sap flow (SF) and their ratio to reference evapotranspiration (Tm) measured during the period of water restrictions in 2009 and 2010 for 'Clementina de Nules' (CN) and 'Navel Lane Late' (NLL) control trees.

\section{Type 1 Type 2}

$(5,12,21,32 \mathrm{~mm}) \quad(10,17,26,38 \mathrm{~mm})$

CN 2009

$\mathrm{SF}$ (mm/day)

1.06

0.65

Tm

0.25

0.16

Tm (Castel, 2000) ${ }^{1}$

0.42

0.42

CN 2010

$\mathrm{SF}$ (mm/day)

1.01

0.71

$\mathrm{Tm}$

0.23

0.16

Tm (Castel 2000) ${ }^{1}$

0.42

0.42

NLL 2010

$(5,15,25,35 \mathrm{~mm})$

$\mathrm{SF}$ (mm/day)

1.43

Tm

0.33

Tm (Castel 2000) ${ }^{1}$

0.45

${ }^{\mathrm{T}}$ Calculated as function of tree canopy ground cover according to Castel (2000) 
Results

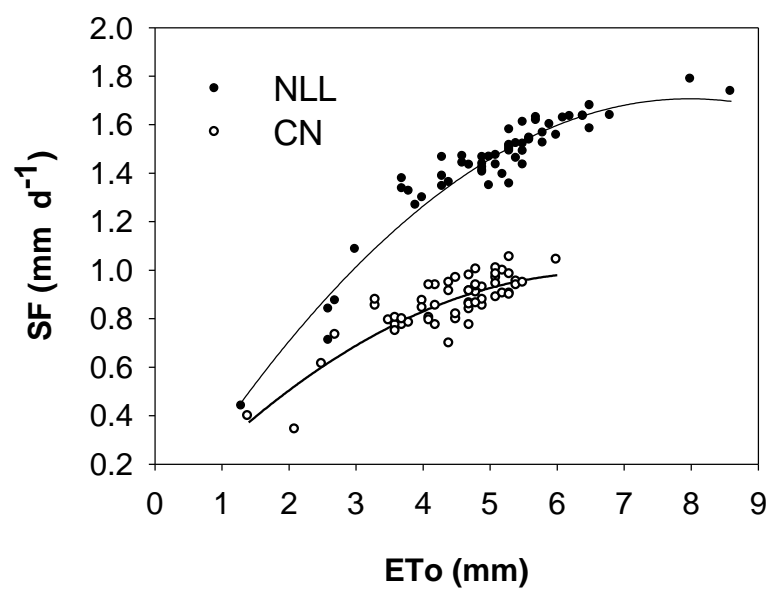

Figure 25 Relationships between daily sap flow (SF) and reference evapotranspiration $\left(\mathrm{ET}_{\mathrm{o}}\right)$ for the control treatment in 'Clementina de Nules' $\left(\mathrm{CN} ; \mathrm{r}^{2}\right.$ $\left.=0.73^{* * *}\right)$, and 'Navel Lane Late' trees (NLL; $\left.\mathrm{r}^{2}=0.92 * * *\right)$, during the period of water restrictions in 2010. Asterisks indicate the level of significance of the regressions. Data for 'Clementina de Nules' are the average of both gauge types.

3.4.3 Sap flow indices for plant water status estimations

\subsubsection{Relative transpiration}

Relative transpiration, RT, is calculated as the sap flow ratio between RDI and control treatments. Previous to the water restrictions, RT was close to 1.0 in 'Navel Lane Late' and 'Clementina de Nules' trees measured with the type 2 gauges. In the case of the type 1 gauges, RT was 1.3. In both species RT decreased during the period of water restrictions following closely the $\Psi_{\mathrm{s}}$ changes (Figure 22 and 23). 
Results

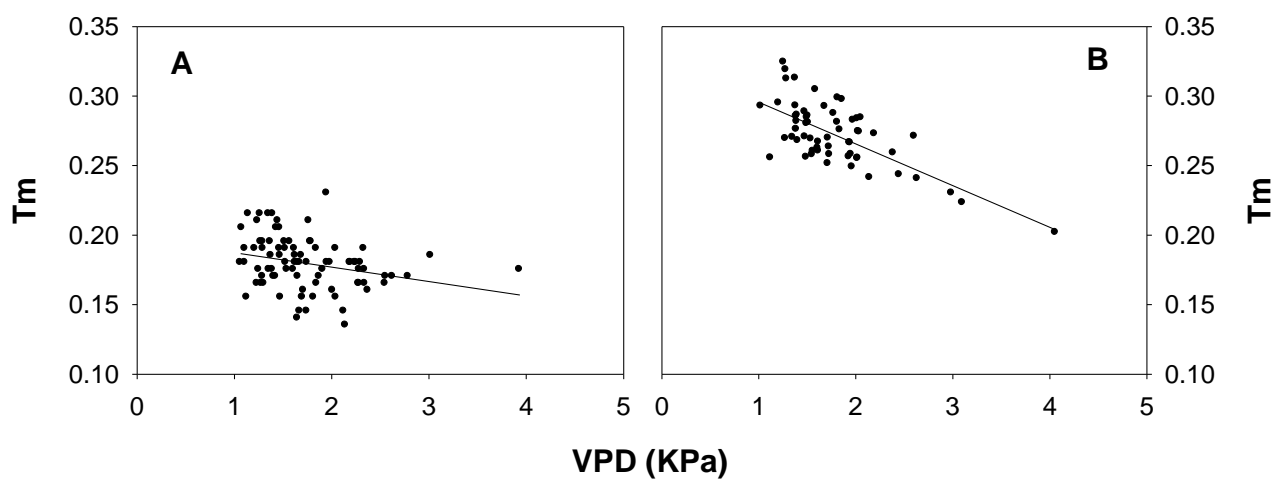

Figure 26 Relationship between maximum transpiration in control trees (Tm) and air vapor pressure deficit (VPD) of 'Clementina de Nules' $\left(\mathrm{A} ; \mathrm{r}^{2}=0.08\right)$ and 'Navel Lane Late' (B, $\left.\mathrm{r}^{2}=0.48^{* *}\right)$. Data for 'Clementina de Nules' are the average of both type of gauges and experimental seasons. Each value comes from a single day with solar radiation above $250 \mathrm{~W} \mathrm{~m}^{-2}$, from July to September. Asterisks indicate the level of significance of the linear regressions.

In 'Clementina de Nules' RT in 2009 started to increase a week before the irrigation was resumed to normal dose coinciding with a period of low evaporative demand and despite the fact that $\Psi_{\mathrm{s}}$ of RDI trees was still around -2.0 MPa (Figure 22). However, in 2010, when irrigation was resumed to normal dose in all trees, there was a quick $\Psi_{\mathrm{s}}$ recovery in RDI trees of both species although the RT took longer to recover (Figure 23).

\subsubsection{Radial heat pulse velocity pattern}

Plant water stress did not clearly affect the radial heat pulse velocity patterns. Control trees of both species, 'Navel Lane Late' RDI trees and 
Results

'Clementina de Nules' RDI trees equipped with the type 2 gauges showed a radial heat pulse velocity pattern characterized by a velocity decrease with depth. Only 'Clementina de Nules' RDI trees instrumented with the type 1 gauges (the shortest ones) showed a different pattern with velocity increasing until $12 \mathrm{~mm}$ depth within the xylem and then decreasing towards the heartwood (Figure 27).

\subsubsection{Nocturnal to diurnal sap flow ratio}

In both species, nocturnal sap flow was detected for all treatments. The N/D evolution showed a general increasing trend as water stress increased in both species. There were in fact significant relationships between relative N/D, calculated as N/D of RDI trees divided by that of control trees, and $\Psi_{\mathrm{s}}$ (Figure 28). As an example, it should be noted that in 'Clementina de Nules' trees equipped with type 1 gauges, on average for the two years of experiment, nighttime water use in control trees was $7 \%$ of total daily water use whilst in RDI trees it was $12 \%$. Absolute N/D values were significantly correlated with $\Psi_{\mathrm{s}}\left(\mathrm{r}^{2}=0.61 * * *\right.$ and $0.57 * * *$ in 'Clementina de Nules' for type1 and type2 gauges, respectively, and $r^{2}=$ $0.59 * * *$ in 'Navel Lane Late'). 
CONTROL

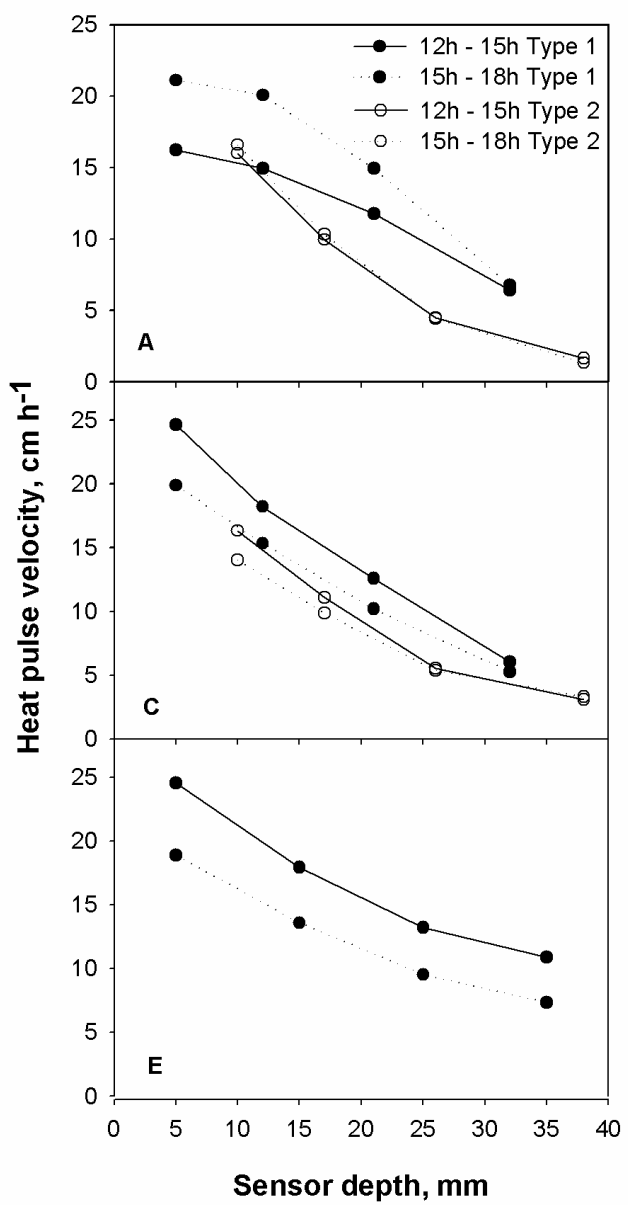

RDI

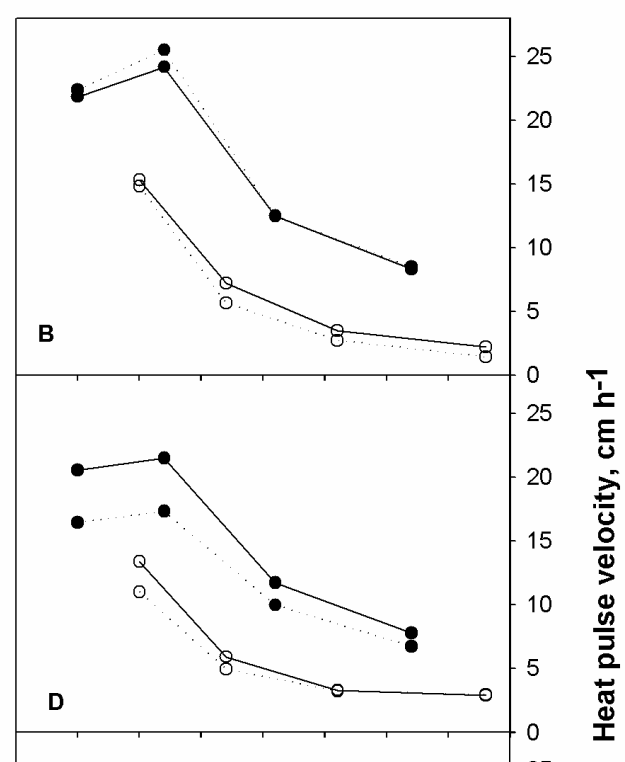

Figure 27 Heat pulse velocity profile (average data for August) during the hours of higher transpiration (from 12 to $15 \mathrm{~h}$ and from $15 \mathrm{~h}$ to $18 \mathrm{~h}$, solar time) for both types of gauge, type $1(5,12,21$ and $32 \mathrm{~mm})$ and type $2(10,17,26$ and 38 $\mathrm{mm}$ ), used in 'Clementina de Nules' Control (A) and RDI (B) trees in 2009, 'Clementina de Nules' Control (C) and RDI (D) trees in 2010, and 'Navel Lane Late' $(5,15,25$ and $35 \mathrm{~mm})$ Control (E) and RDI (F) trees. 
Results

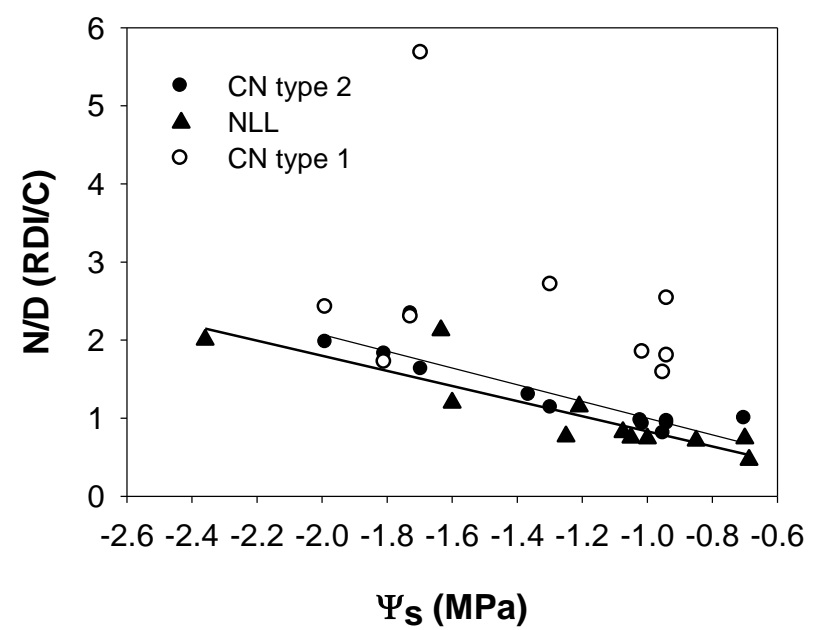

Figure 28 Relationship between midday stem water potential $\left(\Psi_{\text {stem }}\right)$ and relative nocturnal-to-diurnal sap flow ratio (N/D (RDI/C)) in 2010 for 'Clementina de Nules' trees equipped with the type 1 gauges $\left(r^{2}=0.11 ; n=9\right)$, type 2 gauges $\left(r^{2}\right.$ $\left.=0.82^{* * * ;} \mathrm{n}=12\right)$ and 'Navel Lane Late' trees $\left(\mathrm{r}^{2}=0.76^{* * * ;} \mathrm{n}=11\right)$. Asterisks indicate the level of significance of the linear regressions.

\subsection{Experiment 4}

\subsubsection{Meteorological conditions}

During the first experimental season in the persimmon orchard the air temperature $\left(\mathrm{T}_{\mathrm{a}}\right)$ during the hours in which measurements were taken ranged between $30.1{ }^{\circ} \mathrm{C}$ (DOY 170) and $34.6{ }^{\circ} \mathrm{C}$ (DOY 205). Wind speed was similar among the different days (on average $1.6 \pm 0.3 \mathrm{~m} \mathrm{~s}^{-1}$ ). In 2010, average $\mathrm{T}_{\mathrm{a}}$ was $30.2 \pm 4.8{ }^{\circ} \mathrm{C}$ being DOY 239 the warmest day and DOY 138 the coolest (Table 19). 
Results

Table 19 Average values of air temperature $\left(\mathrm{T}_{\mathrm{a}}{ }^{\circ} \mathrm{C}\right)$, solar radiation $\left(\mathrm{Rad}, \mathrm{W} \mathrm{m}{ }^{-2}\right)$, wind velocity $\left(\mathrm{V}, \mathrm{m} \mathrm{s}^{-1}\right)$ and air vapor pressure deficit (VPD, $\mathrm{kPa}$ ) from 13:00 to 15:00h for each day of measurements in the persimmon orchard.

\begin{tabular}{llllll}
\hline 2009 & DOY & $\mathbf{T}_{\mathbf{a}}$ & Rad & $\mathbf{V}$ & VPD \\
& & & & & \\
& 170 & 30.1 & 788.6 & 1.9 & 2.3 \\
& 205 & 34.6 & 793.2 & 1.5 & 2.8 \\
& 226 & 34.5 & 766.2 & 1.2 & 3.8 \\
& 240 & 30.7 & 696.0 & 1.8 & 1.8 \\
& & & & & \\
& 138 & 24.3 & 836.6 & 2.6 & 1.6 \\
& 155 & 29.7 & 851.8 & 2.4 & 1.9 \\
& 169 & 26.2 & 663.2 & 2.0 & 1.5 \\
& 176 & 28.5 & 751.0 & 2.5 & 2.3 \\
& 190 & 31.9 & 823.4 & 1.9 & 2.7 \\
& 204 & 28.9 & 530.6 & 1.7 & 1.5 \\
& 211 & 30.2 & 683.2 & 1.8 & 1.8 \\
& 218 & 29.1 & 723.2 & 1.5 & 1.6 \\
& 232 & 30.5 & 781.2 & 1.1 & 1.9 \\
& 239 & 42.4 & 740.2 & 2.0 & 6.9 \\
\hline
\end{tabular}

For the first year in the citrus experiment, the average $T_{a}$ for the days in which thermal images were taken was $32.9 \pm 1.7^{\circ} \mathrm{C}$ and DOY 204 was the warmest day $\left(34.8^{\circ} \mathrm{C}\right)$. This day was also the windiest with a wind speed of $5.9 \mathrm{~m} \mathrm{~s}^{-1}$. In 2010, $\mathrm{T}_{\mathrm{a}}$ values were lower than in the first experimental season, $30.8 \pm 3.1{ }^{\circ} \mathrm{C}$ on average, being DOY 238 the warmest day (37.1 
Results

${ }^{\circ} \mathrm{C}$ ). Wind speed was similar among the different days (on average $2.4 \pm 0.5$ $\mathrm{m} \mathrm{s}^{-1}$, Table 20).

Table 20 Average values of air temperature $\left(\mathrm{T}_{\mathrm{a}}{ }^{\circ} \mathrm{C}\right)$, solar radiation $\left(\mathrm{Rad}, \mathrm{W} \mathrm{m}{ }^{-2}\right)$, wind velocity $\left(\mathrm{V}, \mathrm{m} \mathrm{s}^{-1}\right)$ and air vapor pressure deficit (VPD, $\mathrm{kPa}$ ) from 13:00 to 15:00h for each day of measurements in the citrus grove.

\begin{tabular}{llllll}
\hline 2009 & DOY & $\mathbf{T}_{\mathbf{a}}$ & $\mathbf{R a d}$ & $\mathbf{V}$ & $\mathbf{V P D}$ \\
& 204 & 34.8 & 854.0 & 5.9 & 4.5 \\
& 218 & 33.2 & 793.2 & 2.8 & 3.0 \\
& 225 & 31.7 & 794.6 & 2.9 & 3.3 \\
& 232 & 34.0 & 788.8 & 3.0 & 4.2 \\
& 239 & 31.6 & 749.6 & 3.3 & 2.7 \\
& 246 & 34.7 & 748.0 & 2.1 & 4.7 \\
& 253 & 30.5 & 734.8 & 2.4 & 3.5 \\
& 216 & 29.9 & 634.2 & 3.3 & 2.0 \\
& 224 & 30.3 & 777.4 & 2.4 & 2.3 \\
& 238 & 37.1 & 760.5 & 2.1 & 4.5 \\
& 246 & 29.2 & 739.3 & 2.0 & 2.5 \\
& 253 & 28.1 & 715.1 & 2.0 & 2.6 \\
& 258 & 30.2 & 662.1 & 2.4 & 2.4 \\
\hline
\end{tabular}

\subsubsection{Persimmon experiment}

During the experimental period of 2009, persimmon control trees had an average $\Psi_{\mathrm{s}}$ value of $-0.73 \pm 0.17 \mathrm{MPa}$ (Figure 29A). The average $\mathrm{g}_{\mathrm{s}}$ 
measured in these trees was $151 \pm 29 \mathrm{mmol} \mathrm{m}^{-2} \mathrm{~s}^{-1}$. WS trees had significantly lower $\Psi_{\mathrm{s}}$ and $\mathrm{g}_{\mathrm{s}}$ values than the control ones, with average values for the whole period of $-1.42 \pm 0.59 \mathrm{MPa}$ and $111 \pm 29 \mathrm{mmol} \mathrm{m}^{-2} \mathrm{~s}^{-1}$, respectively (Figure 29A,B).

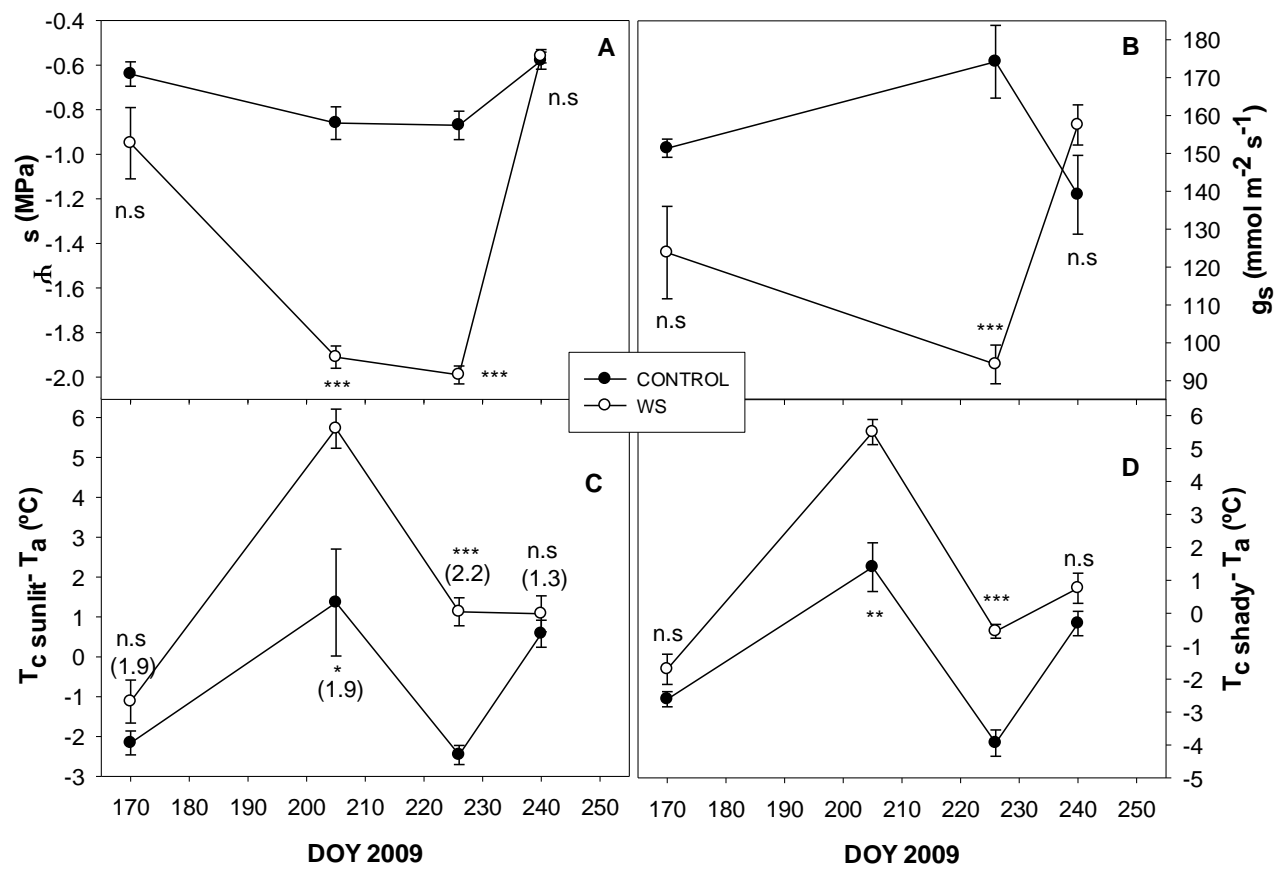

Figure 29 Evolution of stem water potential $\left(\Psi_{\mathrm{s}} ; \mathrm{A}\right)$, stomatal conductance $\left(g_{s} ; B\right)$ and canopy temperature $\left(T_{c}\right)$, measured on the sunlit $(C)$ and shady (D) side of the trees, for the different treatments in the persimmon orchard in 2009. *, **, $* * *$ and $n . s$ denote significant differences at $\mathrm{P}<0.05, \mathrm{P}<0.01, \mathrm{P}<0.001$ and non significant differences, respectively, by Dunnett's test. In graph $\mathrm{C}$, average daily air vapour pressure deficit values of each day are shown between brackets. 
Results

Thermal images from both sides of the canopy (sunlit and shaded side) detected the existing differences in water status between control and WS trees (Figure 29C,D). On average for the period of water restriction, control trees had $\mathrm{T}_{\mathrm{c}}$ sunlit values of $31.2 \pm 3.7^{\circ} \mathrm{C}$ while WS trees had values significantly hotter $\left(33.3 \pm 4.8^{\circ} \mathrm{C}\right)$. $\mathrm{T}_{\mathrm{c}}$ shady values were slightly lower than those obtained from the sunlit side of the canopies. Control trees had an average $\mathrm{T}_{\mathrm{c}}$ shady value of $30.6 \pm 3.4{ }^{\circ} \mathrm{C}$ while $\mathrm{WS}$ trees were $2.0{ }^{\circ} \mathrm{C}$ hotter. During this first experimental season, $\mathrm{T}_{\mathrm{c}}$ in control trees was always between $1.0{ }^{\circ} \mathrm{C}$ above and $2.5^{\circ} \mathrm{C}$ below $\mathrm{T}_{\mathrm{a}}$. Nevertheless in WS trees $\mathrm{T}_{\mathrm{c}}$ was always warmer than ambient temperature (Figure 29C and D). Maximum $T_{c}$ differences between treatments $\left(\Delta \mathrm{T}_{\mathrm{c}}\right)$ were observed on DOY 205 when WS trees had $\Psi_{\mathrm{s}}$ values of $-1.92 \mathrm{MPa}$ and were almost $6{ }^{\circ} \mathrm{C}$ warmer than $\mathrm{T}_{\mathrm{a}}$. These maximum $\Delta \mathrm{T}_{\mathrm{c}}$ values varied slightly depending on the canopy side from where images were taken, and were of 4.4 and $4.1^{\circ} \mathrm{C}$, respectively, for the sunlit and shady sides. When water restrictions ended and irrigation was resumed to normal dose (DOY 240), WS trees returned to $\Psi_{\mathrm{s}}, \mathrm{g}_{\mathrm{s}}$ and $\mathrm{T}_{\mathrm{c}}$ values similar to those of the control trees (Figure 29). On days when control and WS treatments had $\Psi_{\mathrm{s}}$ differences above 0.4 MPa (DOY 170, 205 and 226), $T_{c}-T_{a}$ measured on either side of the canopy was well correlated with $\Psi_{\mathrm{s}}$ and $\mathrm{g}_{\mathrm{s}}$ (Table 21).

In 2010, water stress experienced by WS trees was lower than in 2009. The average $\Psi_{\mathrm{s}}$ value for the control trees was $-0.49 \pm 0.13 \mathrm{MPa}$ while in the WS treatment it was $-0.88 \pm 0.43 \mathrm{MPa}$ (Figure 30A). Similarly, average $g_{s}$ values were of $134 \pm 26 \mathrm{mmol} \mathrm{m}^{-2} \mathrm{~s}^{-1}$ and $118 \pm 20 \mathrm{mmol} \mathrm{m}^{-2} \mathrm{~s}^{-1}$ for the control and WS trees, respectively (Figure 30B). 
Results

Table 21 Correlation coefficient, $\mathrm{R}^{2}$ of the relationships among the different water status indicators in the persimmon experiment. *, ** and *** denote significant differences at $\mathrm{P}<0.05, \mathrm{P}<0.01$ and $\mathrm{P}<0.001$ respectively, by Dunnett's test.

\begin{tabular}{|c|c|c|c|c|c|c|c|}
\hline \multirow[b]{2}{*}{ DOY } & \multicolumn{5}{|c|}{$\mathbf{R}^{2}$} & \multirow{3}{*}{$\mathbf{n}$} & \multirow[b]{2}{*}{$\Psi_{\mathrm{s}}$ range } \\
\hline & $\begin{array}{c}\mathbf{T}_{\mathrm{c}} \text { sunlit }-\mathbf{T}_{\mathrm{a}} \\
\text { vs. } \Psi_{\mathrm{s}}\end{array}$ & $\begin{array}{c}\mathbf{T}_{\mathrm{c}} \text { shady }-\mathbf{T}_{\mathrm{a}} \\
\text { vs. } \Psi_{\mathrm{s}}\end{array}$ & $\begin{array}{c}\mathbf{T}_{\mathrm{c}} \text { sunlit }-\mathbf{T}_{\mathrm{a}} \\
\text { vs. } \mathrm{g}_{\mathrm{s}}\end{array}$ & $\begin{array}{c}\mathbf{T}_{\mathrm{c}} \text { shady }-\mathbf{T}_{\mathrm{a}} \\
\text { vs. } \mathrm{g}_{\mathrm{s}}\end{array}$ & $\Psi_{\mathrm{s}}$ vs. $\mathrm{g}_{\mathrm{s}}$ & & \\
\hline Persimmon 2009 & & & & & & & \\
\hline 170 & $0.76 * * *$ & $0.72 * * *$ & $0.79 * * *$ & $0.76 * * *$ & $0.69 * *$ & 12 & 1.1 \\
\hline 205 & $0.47 * *$ & $0.65 * * *$ & $0.52 *$ & $0.80 * * *$ & $0.53 * *$ & 16 & 1.3 \\
\hline 226 & $0.90 * * *$ & $0.81 * * *$ & $0.70 * * *$ & $0.66 * * *$ & $0.90 * * *$ & 18 & 1.5 \\
\hline 240 & 0.00 & 0.24 & 0.02 & 0.12 & 0.05 & 18 & 0.4 \\
\hline \multicolumn{8}{|l|}{ Persimmon 2010} \\
\hline 138 & 0.09 & - & 0.08 & - & 0.10 & 17 & 0.2 \\
\hline 155 & 0.03 & - & 0.01 & - & 0.23 & 16 & 0.2 \\
\hline 169 & 0.00 & - & $0.35 *$ & - & 0.00 & 18 & 0.2 \\
\hline 176 & 0.00 & - & 0.02 & - & 0.25 & 18 & 0.1 \\
\hline 190 & $0.66^{* * *}$ & - & $0.42 *$ & - & $0.43 *$ & 17 & 0.8 \\
\hline 204 & $0.57 * * *$ & - & 0.19 & - & $0.30 *$ & 22 & 1.4 \\
\hline 211 & $0.40 * *$ & - & 0.11 & - & 0.16 & 17 & 0.7 \\
\hline 218 & $0.59 * * *$ & - & $0.60 * * *$ & - & $0.20 *$ & 16 & 0.9 \\
\hline 232 & 0.00 & - & 0.17 & - & 0.01 & 18 & 0.3 \\
\hline 239 & $0.70 * * *$ & - & $0.46^{* *}$ & - & $0.71 * * *$ & 18 & 1.8 \\
\hline
\end{tabular}


Results

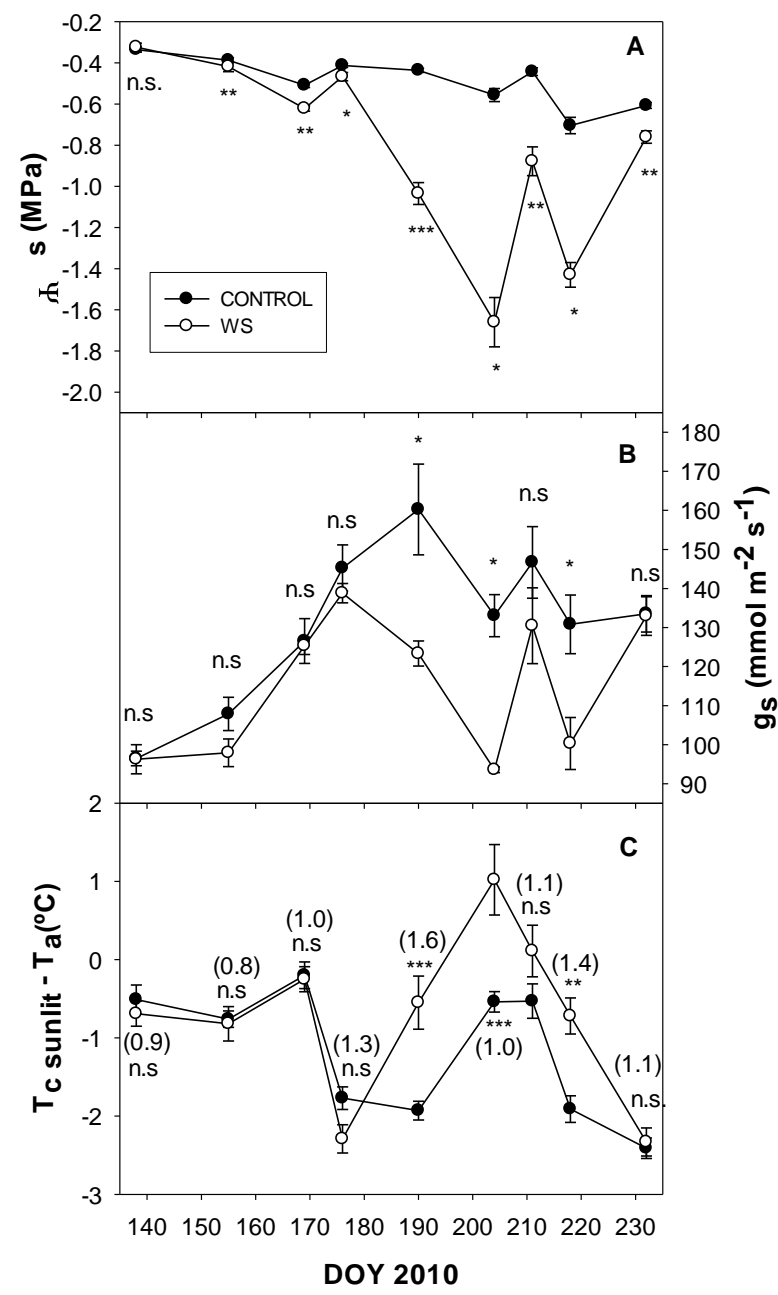

Figure 30 Evolution of stem water potential $\left(\Psi_{\mathrm{s}} ; \mathrm{A}\right)$, stomatal conductance (gs; B) and canopy temperature measured on the sunlit side of the trees $\left(\mathrm{T}_{\mathrm{c}}\right.$ sunlit; C) at midday for the different treatments in the persimmon orchard during 2010. *, $* *, * * *$ and n.s denote significant differences at $\mathrm{P}<0.05, \mathrm{P}<0.01, \mathrm{P}<0.001$ and non significant differences, respectively, by Dunnett's test. In graph $\mathrm{C}$, average daily air vapour pressure deficit values of each day are shown between brackets. 
Results

Based on the results obtained during 2009 for the effect of canopy side on $\mathrm{T}_{\mathrm{c}}$, in 2010 only $\mathrm{T}_{\mathrm{c}}$ sunlit was measured. During this year, $\mathrm{T}_{\mathrm{c}}$ in control trees remained always below $\mathrm{T}_{\mathrm{a}}$. WS trees, however, surpassed $\mathrm{T}_{\mathrm{a}}$ on DOY 204 by $1.0{ }^{\circ} \mathrm{C}$ (Figure 30C), day in which trees from this treatment reached the lowest $\Psi_{\mathrm{s}}$ values $(-1.66 \mathrm{MPa})$ and the maximum $\Delta \mathrm{T}_{\mathrm{c}}\left(1.5^{\circ} \mathrm{C}\right)$.

The best correlations between $T_{c}-T_{a}$ and $\Psi_{s}$ or $g_{s}$ were found in days with differences of $\Psi_{\mathrm{s}}$ between treatments higher than $0.3 \mathrm{MPa}$ (Table 21).

Pooling data from each entire experimental season $T_{c}-T_{a}$ was significantly related with $\Psi_{\mathrm{s}}(\mathrm{P}<0.001$, Figure 31$)$ although no clear relationship with $\mathrm{g}_{\mathrm{s}}$ was observed (results not shown).

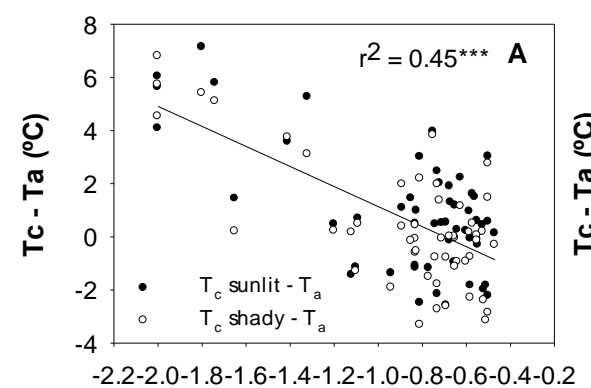

$\Psi_{S}$ (MPa)

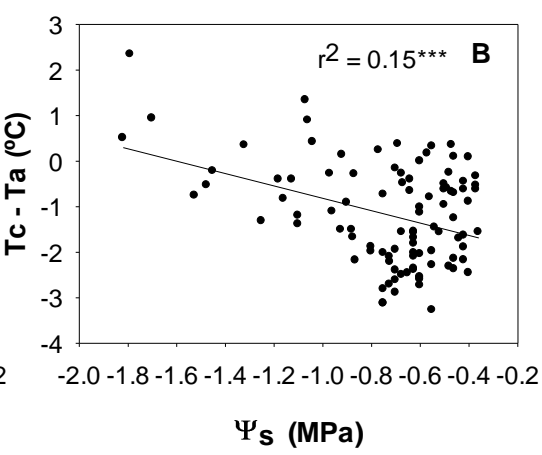

Figure 31 Relationship between $T_{c}-T_{a}$ and $\Psi_{s}$ in persimmon trees for 2009 (A) and 2010 (B). Each value is a single tree measurement $(n=105$ in figure A and 98 in $\mathrm{B})$. 
Results

The day in which $\mathrm{T}_{\mathrm{c}}$ was measured from a truck-crane at $12 \mathrm{~m}$ above the canopies (DOY 239), control and WS trees had $\Psi_{\mathrm{s}}$ values of $-0.99 \mathrm{MPa}$ and -1.91 MPa, respectively. On average $\mathrm{T}_{\mathrm{c}}$ was of $38.8^{\circ} \mathrm{C}$ in the control treatment and $41.3{ }^{\circ} \mathrm{C}$ in the WS one. There were statistically significant $(\mathrm{P}<0.05)$ correlations between $\mathrm{T}_{\mathrm{c}}-\mathrm{T}_{\mathrm{a}}$, measured from the crane, and $\mathrm{g}_{\mathrm{s}}$ or $\Psi_{\text {s }}$ measurements (Figure 32).

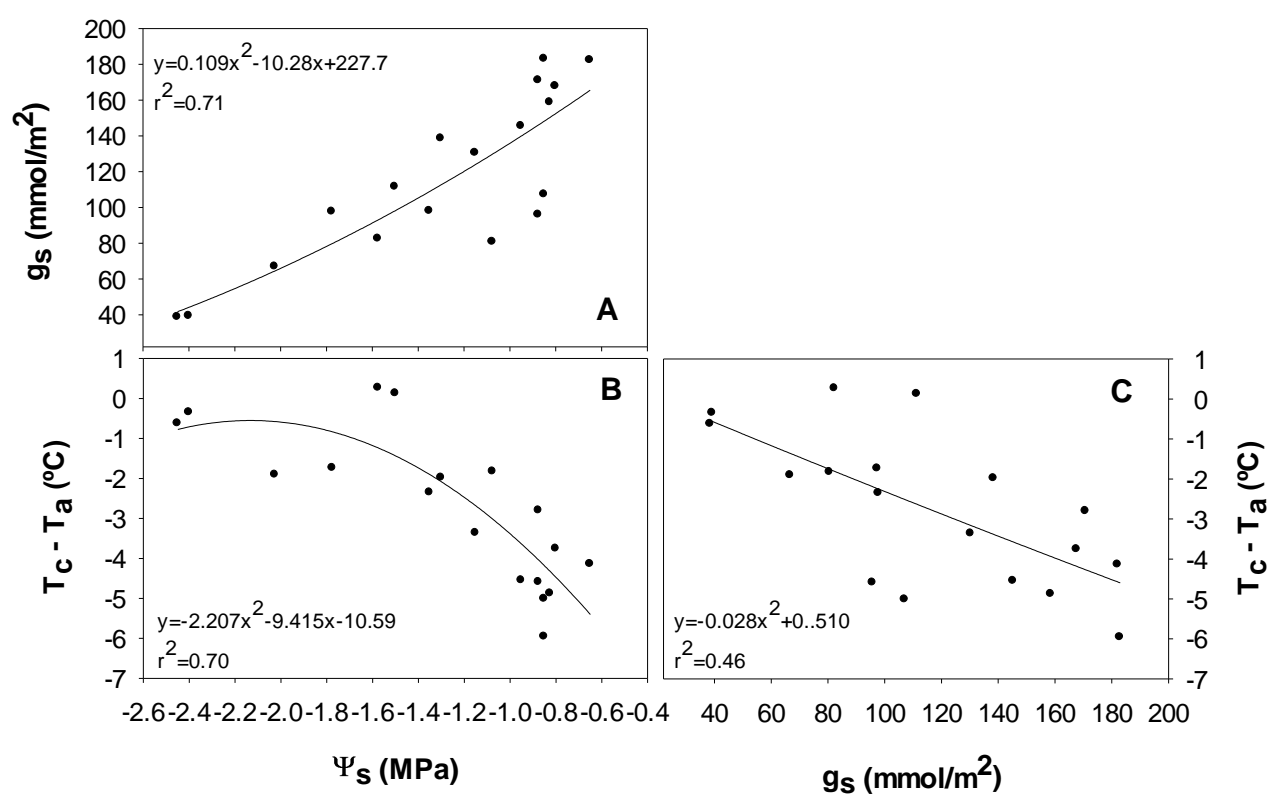

Figure 30 Relationships between $g_{s}$ and $\Psi_{s}(A), T_{c}$ and $\Psi_{s}(B)$ and $T_{c}$ and $g_{s}(C)$ for DOY 239 when thermographic images were taken from a crane in the persimmon orchard. Each value is a single tree measurement. 
Results

\subsubsection{Citrus experiment}

In $2009 \Psi$ s values registered in the control trees were quite similar during the seven days in which images were taken with an average value of $-1.00 \pm 0.10 \mathrm{Mpa}$ (Figure 33A). Trees from both water-stressed treatments showed $\Psi_{\mathrm{s}}$ values significantly more negative than the control ones reaching minimum values of $-1.47 \mathrm{MPa}$ in the RDI-1 treatment and of $-1.67 \mathrm{MPa}$ in the RDI-2. In spite of these important differences in $\Psi_{\mathrm{s}}$, neither images taken from the sunlit side of the canopy nor those taken from the shady side allowed detecting $\mathrm{T}_{\mathrm{c}}$ differences between control and water-stressed trees. Only on DOY 218 there was a significant, but weak correlation between $\mathrm{T}_{\mathrm{c}}$ $\mathrm{T}_{\mathrm{a}}$ and $\Psi_{\mathrm{s}}$ (Table 22).

In general, trees from all treatments, regardless their water status, maintained $\mathrm{T}_{\mathrm{c}}$ values between $1{ }^{\circ} \mathrm{C}$ above and $2{ }^{\circ} \mathrm{C}$ below ambient temperature during this season with the exception of the last measurement day (DOY 253) in which $\mathrm{T}_{c}-\mathrm{T}_{\mathrm{a}}$ decreased to values of $-5^{\circ} \mathrm{C}$ (Figure 33).

During 2010 frontal images were only taken from the sunlit side of the canopies. Furthermore, thermal images from $1 \mathrm{~m}$ above the canopies were also taken in three different days (DOY's 224, 238 and 246) and in one additional day from $12 \mathrm{~m}$ above trees with a truck-crane (DOY 253). During this experimental season there were also significant differences in $\Psi_{\text {s }}$ between treatments (Figure 34A). Control trees had an average value of $0.94 \pm 0.09 \mathrm{MPa}$ while in water-stressed trees it was of $-1.11 \pm 0.17$ and $1.34 \pm 0.29 \mathrm{MPa}$ in the RDI-1 and RDI-2 treatments, respectively. 
Results

Table 22 Correlation coefficient, $\mathrm{R}^{2}$, of the relationships between $T_{c}-T_{a}$ and $\Psi_{s}$ in the citrus experiment for each season.

$*, * *, * * *$ and $\mathrm{ns}$ denote significant differences at $\mathrm{P}<0.05, \mathrm{P}<0.01, \mathrm{P}<0.001$ and non significant differences, respectively, by Dunnett's test.

\begin{tabular}{|c|c|c|c|c|c|c|}
\hline \multirow[b]{2}{*}{$\begin{array}{l}\text { DOY } \\
\text { Citrus } 2009\end{array}$} & \multicolumn{2}{|c|}{$\mathbf{R}^{2}$} & \multirow[b]{2}{*}{$\mathbf{n}$} & \multirow{2}{*}{$\frac{\mathbf{R}^{2}}{\text { T}_{\mathrm{c}} \text { zenith }- \text { Ta vs. } \Psi_{\mathrm{s}}}$} & \multirow[b]{2}{*}{$\mathbf{n}$} & \multirow[b]{2}{*}{$\Psi_{\mathrm{s}}$ rang } \\
\hline & $T_{c}$ sunlit - Ta vs. $\Psi_{s}$ & $T_{c}$ shady - Ta vs. $\Psi_{s}$ & & & & \\
\hline 204 & 0.01 & 0.00 & 24 & - & - & 0.5 \\
\hline 218 & $0.20^{*}$ & $0.21^{*}$ & 24 & - & - & 1.1 \\
\hline 225 & 0.01 & 0.06 & 24 & - & - & 0.7 \\
\hline 232 & 0.02 & 0.13 & 24 & - & - & 0.9 \\
\hline 239 & 0.08 & 0.09 & 24 & - & - & 1.4 \\
\hline 246 & 0.04 & 0.01 & 24 & - & - & 1.1 \\
\hline 253 & 0.01 & 0.04 & 24 & - & - & 1.3 \\
\hline \multicolumn{7}{|l|}{ Citrus 2010} \\
\hline 216 & 0.03 & - & 24 & - & - & 0.5 \\
\hline 224 & $0.27 * *$ & - & 33 & $0.23^{*}$ & 20 & 0.7 \\
\hline 238 & $0.14 *$ & - & 29 & 0.43 & 8 & 1.0 \\
\hline 246 & $0.32 * * *$ & - & 35 & $0.56^{* * *}$ & 20 & 1.1 \\
\hline 253 & - & - & - & $0.29 * *$ & 25 & 1.6 \\
\hline 258 & $0.20^{*}$ & - & 24 & - & - & 1.2 \\
\hline
\end{tabular}


Results

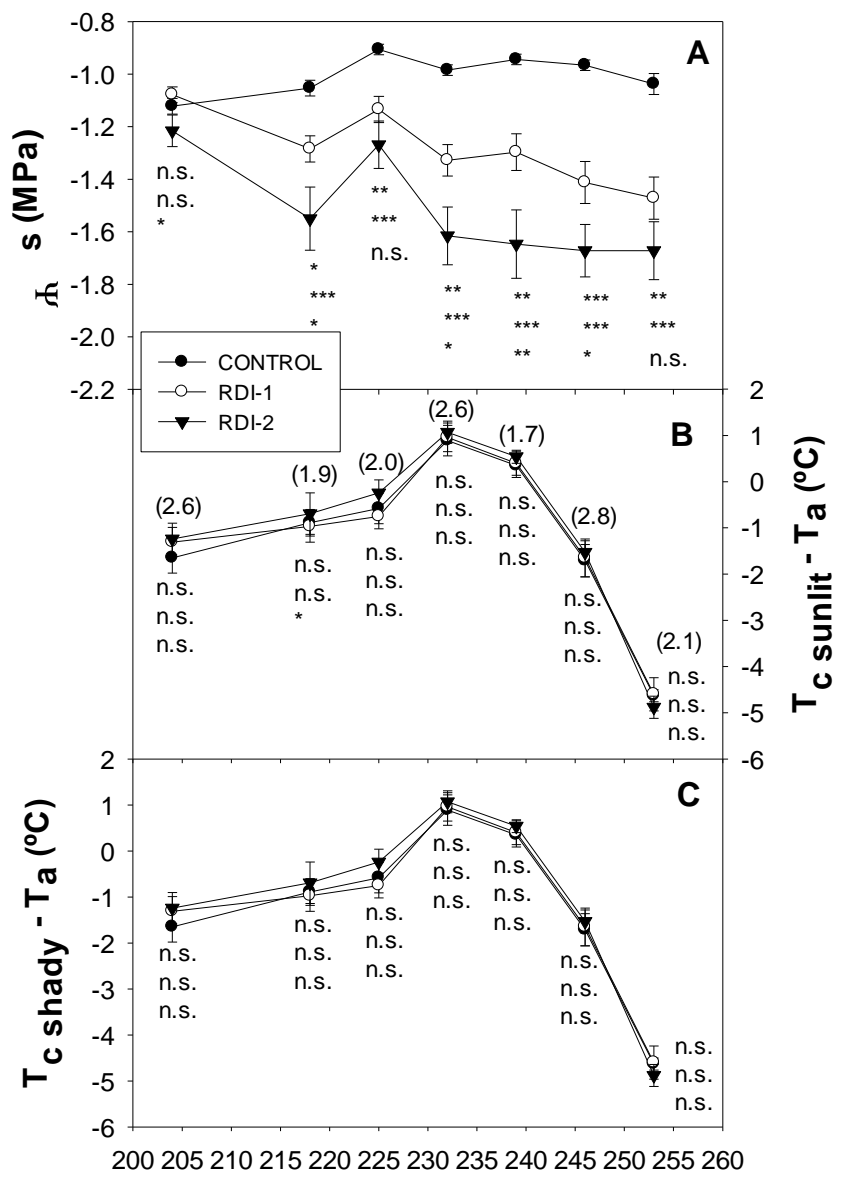

DOY 2009

Figure 33 Evolution of stem water potential $\left(\Psi_{\mathrm{s}} ; \mathrm{A}\right)$ and canopy temperature $\left(\mathrm{T}_{\mathrm{c}}\right)$, measured at midday on the sunlit $(\mathrm{B})$ and shady $(\mathrm{C})$ side of the trees, for the different treatments in the citrus orchard during 2009. *, **, *** and n.s. denote significant differences at $\mathrm{P}<0.05, \mathrm{P}<0.01, \mathrm{P}<0.001$ and non significant differences, respectively, by Dunnett's test. For each day, the top asterisks or n.s. indicate differences between control and RDI-1, the middle ones between control and RDI-2 and the bottom ones between RDI- 1 and RDI-2. 
Results

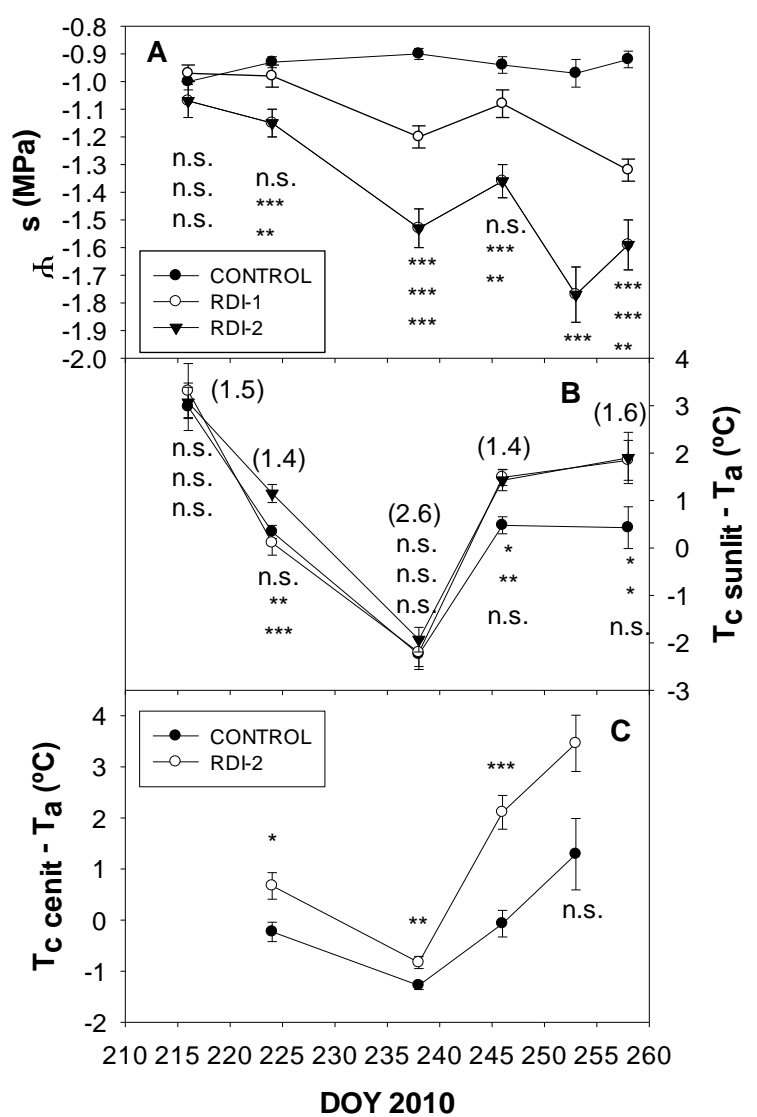

Figure 34 Evolution of stem water potential $\left(\Psi_{s} ; A\right)$ and canopy temperature $\left(\mathrm{T}_{\mathrm{c}}\right)$ measured at midday on the sunlit side of the trees $(\mathrm{B})$ and from 12 $m$ above the canopy $(\mathrm{C})$ for the different treatments in the citrus orchard during 2010. *, **, *** and n.s. denote significant differences at $\mathrm{P}<0.05, \mathrm{P}<0.01, \mathrm{P}<0.001$ and non significant differences, respectively, by Dunnett's test. For each day, the top asterisks or n.s. indicate differences between control and RDI-1, the middle ones between control and RDI-2 and the bottom ones between RDI-1 and RDI-2. In graph $\mathrm{B}$, air vapour pressure deficit values of each day are shown between brackets. 
Results

In days with differences in $\Psi_{\mathrm{s}}$, with the exception of DOY $238, \mathrm{~T}_{\mathrm{c}}$ $\mathrm{T}_{\mathrm{a}}$ was significantly higher in water-stressed trees than in control ones. The first day of measurements (DOY 216) $\mathrm{T}_{\mathrm{c}}$ of all the trees was $3.0^{\circ} \mathrm{C}$ warmer than $\mathrm{T}_{\mathrm{a}}$. Henceforth, the canopy to air temperature difference in control trees ranged between 0.5 and $-2.2{ }^{\circ} \mathrm{C}$ while in both deficit irrigated treatments ranged between 2.0 and $-2.2^{\circ} \mathrm{C}$ (Figure 34B).

When images were taken from $1 \mathrm{~m}$ above the canopies, differences in $\Psi_{\mathrm{s}}$ of $0.35 \mathrm{MPa}$ between control and stressed treatments represented an increase of $\mathrm{T}_{c}$ in RDI-2 trees of $1.36^{\circ} \mathrm{C}$. On DOY 253, when images were taken from the trunk-crane, $\Psi_{\mathrm{s}}$ in RDI-2 trees was $0.97 \mathrm{MPa}$ lower than in the control ones. In this case, the $\Delta \mathrm{T}_{\mathrm{c}}$ between treatments was higher than in the other cases, $1.73{ }^{\circ} \mathrm{C}$. The best correlations between $\mathrm{T}_{\mathrm{c}}-\mathrm{T}_{\mathrm{a}}$ and $\Psi_{\mathrm{s}}$ (on average $\left.\mathrm{r}^{2}=0.51^{* *}\right)$ were found on DOY's 238 and 246 when images were taken from $1 \mathrm{~m}$ above the canopies and control and water-stressed trees showed differences in $\Psi_{s}$ higher than $1 \mathrm{MPa}$ (Table 22). For this experimental season and pooling data from days with similar VPD values, $\mathrm{T}_{\mathrm{c}}-\mathrm{T}_{\mathrm{a}}$ had a significant relationship with $\Psi_{\mathrm{s}}\left(\mathrm{r}^{2}=0.42^{*}\right.$ when each single measurement was taken into account, and $r^{2}=0.76 * *$ when data were grouped by treatments; Figure 35).

The CWSI ranged from 0.33, value registered in the control treatment, to 0.51 , registered in the most stressed one. RDI-1 trees differed significantly from the control ones on DOY's 246 and 258 as well as RDI-2 trees which also differed on DOY 224 (Table 23). Pooling data from all 
days of measurements, CWSI was significant but poorly related with $\Psi_{\mathrm{s}}\left(\mathrm{r}^{2}\right.$ $=0.15^{* * *}$, results not shown).
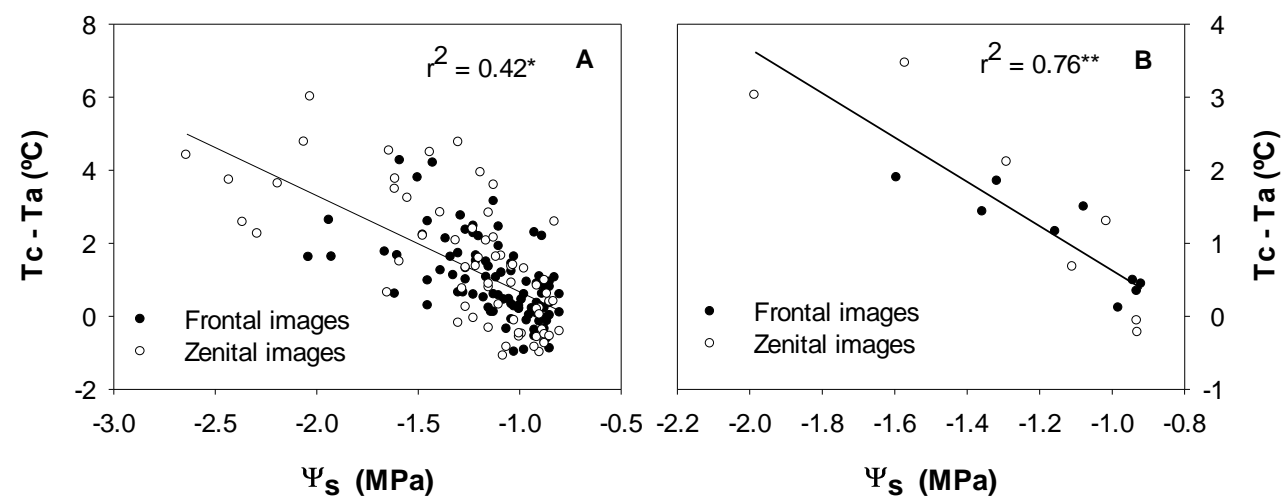

Figure 35 Relationship between $T_{c}-T_{a}$ and $\Psi_{s}$ at midday in the citrus orchard for the 2010 season. In figure A each point is a single tree measurement (n =94). In figure B data are grouped by treatments $(n=16)$.

\subsubsection{Sensitivity of the indicators}

In both experiments, $T_{c}$ was the water stress indicator that showed less variability among trees within a treatment and it was also the most sensitive (Table 24). Differences in sensitivity between $T_{c}$ and the rest of the indicators were more marked during the second experimental season in which $\Psi_{\mathrm{s}}, \mathrm{g}_{\mathrm{s}}$ and CWSI had similar values. 
Results

3.5.5 Assessment of intra-crown temperature variability for water stress detection

The intra-crown temperature variability, $\sigma$, was determined in days when clear differences in plant water status among treatments existed (Table 25). Despite this fact, $\sigma$ did not differ significantly between treatments. This is because the within-treatments coefficient of variation observed in both orchards for $\sigma$ was very high, and it ranged from 22 to $133 \%$.

Table 23 Stem water potential $\left(\psi_{\mathrm{s}}, \mathrm{MPa}\right)$, canopy temperature $\left(\mathrm{T}_{\mathrm{c}},{ }^{\circ} \mathrm{C}\right)$ and the crop water stress index (CWSI) of each treatment during the second experimental season (2010) in the citrus grove. Values followed by different letters are significantly different at $\mathrm{P}<0.05$ from ANOVA.

\begin{tabular}{lccc}
\hline & $\boldsymbol{\psi}_{\mathrm{s}}$ & $\mathbf{T}_{\mathbf{c}}$ & $\mathbf{C W S I}$ \\
DOY 224 & & & \\
Control & $-0.93 \mathrm{a}$ & $30.44 \mathrm{a}$ & $0.43 \mathrm{a}$ \\
RDI-1 & $-0.98 \mathrm{a}$ & $30.66 \mathrm{a}$ & $0.41 \mathrm{a}$ \\
RDI-2 & $-1.15 \mathrm{~b}$ & $31.42 \mathrm{~b}$ & $0.48 \mathrm{~b}$ \\
DOY 238 & & & \\
Control & $-0.90 \mathrm{a}$ & 34.89 & 0.49 \\
RDI-1 & $-1.20 \mathrm{~b}$ & 34.93 & 0.49 \\
RDI-2 & $-1.53 \mathrm{c}$ & 35.19 & 0.51 \\
DOY 246 & & & \\
Control & $-0.94 \mathrm{a}$ & $29.72 \mathrm{a}$ & $0.33 \mathrm{a}$ \\
RDI-1 & $-1.08 \mathrm{a}$ & $30.67 \mathrm{~b}$ & $0.40 \mathrm{~b}$ \\
RDI-2 & $-1.36 \mathrm{~b}$ & $30.73 \mathrm{~b}$ & $0.39 \mathrm{~b}$ \\
DOY 258 & & & \\
Control & $-0.92 \mathrm{a}$ & $30.64 \mathrm{a}$ & $0.40 \mathrm{a}$ \\
RDI-1 & $-1.32 \mathrm{~b}$ & $32.06 \mathrm{~b}$ & $0.48 \mathrm{~b}$ \\
RDI-2 & $-1.59 \mathrm{c}$ & $32.11 \mathrm{~b}$ & $0.48 \mathrm{~b}$ \\
\hline
\end{tabular}


Results

Table 24 Sensitivity of the different water stress indicators for each species and experimental season.

\begin{tabular}{lcccccc}
\hline & \multicolumn{3}{c}{ Persimmon } & \multicolumn{3}{c}{ Orange } \\
\cline { 2 - 7 } & $\mathbf{T}_{\mathbf{c}}$ & $\mathbf{g}_{\mathrm{s}}$ & $\boldsymbol{\Psi}_{\mathrm{s}}$ & $\mathbf{T}_{\mathbf{c}}$ & $\Psi_{\mathrm{s}}$ & CWSI \\
$\mathbf{2 0 0 9}$ & & & & & & \\
Signal & 1.08 & 1.36 & 1.94 & - & 1.40 & - \\
Noise & 0.15 & 0.26 & 0.41 & - & 0.20 & - \\
Sensitivity (signal/noise) & 7.20 & 5.23 & 4.73 & - & 7.00 & - \\
$\mathbf{2 0 1 0}$ & & & & & & \\
Signal & 1.04 & 1.38 & 1.86 & 1.05 & 1.48 & 1.11 \\
Noise & 0.05 & 0.33 & 0.37 & 0.06 & 0.20 & 0.16 \\
Sensitivity (signal/noise) & 20.80 & 4.18 & 5.03 & 17.5 & 7.40 & 7.07 \\
\hline
\end{tabular}

Table 25 Average values for intra-crown temperature variability $(\sigma)$, coefficient of variation (C.V.) observed within treatments for the intra-crown temperature variability, stem water potential $\left(\Psi_{\mathrm{s}}\right)$ and canopy temperature $\left(\mathrm{T}_{\mathrm{c}}\right)$ in citrus and persimmon trees for each treatment and season. Values followed by different letters are significantly different at $\mathrm{P}<0.05$ from ANOVA.

\begin{tabular}{lcccc}
\hline Citrus 2009 & $\boldsymbol{\sigma}$ & $\mathbf{C . V}$ & $\Psi_{\mathrm{s}}$ & $\mathbf{T}_{\mathbf{c}}$ \\
$\begin{array}{l}\text { Control } \\
\text { RDI-1 }\end{array}$ & 1.28 & 0.28 & $-0.97 \mathrm{a}$ & 33.2 \\
RDI-2 & 1.08 & 0.36 & $-1.31 \mathrm{~b}$ & 32.8 \\
Citrus 2010 & 1.17 & 0.39 & $-1.57 \mathrm{c}$ & 33.1 \\
Control & & & & \\
RDI-1 & 1.78 & 1.33 & $-0.92 \mathrm{a}$ & 32.0 \\
RDI-2 & 1.87 & 1.09 & $-1.09 \mathrm{~b}$ & 32.5 \\
$\begin{array}{l}\text { Persimmon 2009 } \\
\text { Control }\end{array}$ & 1.92 & 1.03 & $-1.33 \mathrm{c}$ & 32.7 \\
WS & & & & \\
Persimmon 2010 & 2.08 & 0.22 & $-0.86 \mathrm{a}$ & $34.1 \mathrm{a}$ \\
Control & 2.36 & 0.26 & $-1.96 \mathrm{~b}$ & $37.5 \mathrm{~b}$ \\
WS & & & & \\
\hline
\end{tabular}


Results

\subsection{Experiment 5}

Average daily $\mathrm{ET}_{\mathrm{o}}$ and VPD values registered in the Clementine orchard during the experiment were $4.1 \mathrm{~mm}$ and $1.5 \mathrm{kPa}$, respectively. VPD values for the days when $\Psi$ s and gs were also measured are shown in table 26. No rainfall events occurred during this period. Thus, differences in plant water status between treatments were exclusively a consequence of the differential irrigation treatments applied.

During most of the experimental period, control trees had $\Psi_{\mathrm{s}}$ values around -1.08 $\mathrm{MPa}$, while RDI trees reached minimum values of $-1.84 \mathrm{MPa}$ (Figure 36A). $\Psi_{\mathrm{s}}$ values in NI trees fell down to $-2.67 \mathrm{MPa}$ and then increase to values similar to those registered in the RDI trees (DOY 242), when irrigation was resumed as in that treatment. The decrease in plant water status led to a reduction in stomatal conductance (Figure 36B). On average, control trees had $\mathrm{g}_{\mathrm{s}}$ values of $119 \mathrm{mmol} \mathrm{m}^{-2} \mathrm{~s}^{-1}$, while the corresponding values for RDI and NI trees were 96 and $77 \mathrm{mmol} \mathrm{m} \mathrm{m}^{-1}$, respectively.

The mean absolute sap flow value in control trees during the experimental period was of $1.0 \mathrm{~mm} \mathrm{day}^{-1}$ while in the RDI treatment this value was $15 \%$ lower. The average daily absolute sap flow values obtained during the period of water restrictions were significantly correlated with $\Psi_{\text {s }}$ $\left(\mathrm{r}^{2}=0.50^{* *}\right)$ and $\mathrm{g}_{\mathrm{s}}\left(\mathrm{r}^{2}=0.57^{* * *}\right)$ measurements (Figure 37A). These correlations, however, were higher when relative values of sap flow were compared with $\Psi_{\mathrm{s}}\left(\mathrm{r}^{2}=0.85^{* * *}\right)$ and $\mathrm{g}_{\mathrm{s}}\left(\mathrm{r}^{2}=0.80^{* *}\right)$ measurements of the RDI trees (Figure 37B). 
Results

Table 26 Relationships between canopy temperature measured with a hand-operated thermographic camera, minus air temperature $\left(T_{c}-T_{a}\right)$, stem water potential $\left(\Psi_{s}\right)$ and stomatal conductance $\left(g_{s}\right)$. For each day, the range of $\Psi_{\mathrm{s}}$ and air vapor pressure deficit (VPD) values are also shown.

\begin{tabular}{|c|c|c|c|c|c|c|c|c|c|c|c|}
\hline DOY & 207 & 216 & 223 & 229 & 236 & 242 & 249 & 256 & 259 & 264 & 270 \\
\hline$\Psi_{s}$ vs. $T_{c}-T_{a}($ Thermal imagery) & 0.09 & 0.08 & 0.32 & 0.64 & 0.70 & 0.52 & 0.52 & 0.41 & 0.07 & 0.19 & 0.04 \\
\hline$g_{s}$ vs. $T_{c}-T_{a}($ Thermal imagery) & 0.02 & 0.37 & 0.14 & 0.78 & 0.76 & 0.18 & 0.38 & 0.34 & 0.22 & 0.05 & - \\
\hline$\Psi_{s}$ vs. $T_{c}-T_{a}(I R T s)$ & 0.10 & 0.28 & 0.41 & 0.14 & 0.24 & 0.01 & 0.03 & 0.03 & 0.00 & 0.24 & 0.20 \\
\hline$\Psi_{\mathrm{s}}$ vS. $\mathrm{g}_{\mathrm{s}}$ & 0.51 & 0.23 & 0.11 & 0.81 & 0.70 & 0.56 & 0.56 & 0.78 & 0.59 & 0.13 & - \\
\hline$\Psi_{\mathrm{s}}$ range & 0.30 & 0.41 & 0.53 & 1.19 & 1.44 & 1.01 & 1.15 & 1.10 & 0.33 & 0.49 & 0.30 \\
\hline VPD & 3.14 & 2.23 & 2.15 & 2.94 & 2.67 & 3.15 & 2.22 & 3.05 & 2.60 & 2.32 & 2.28 \\
\hline
\end{tabular}


Results

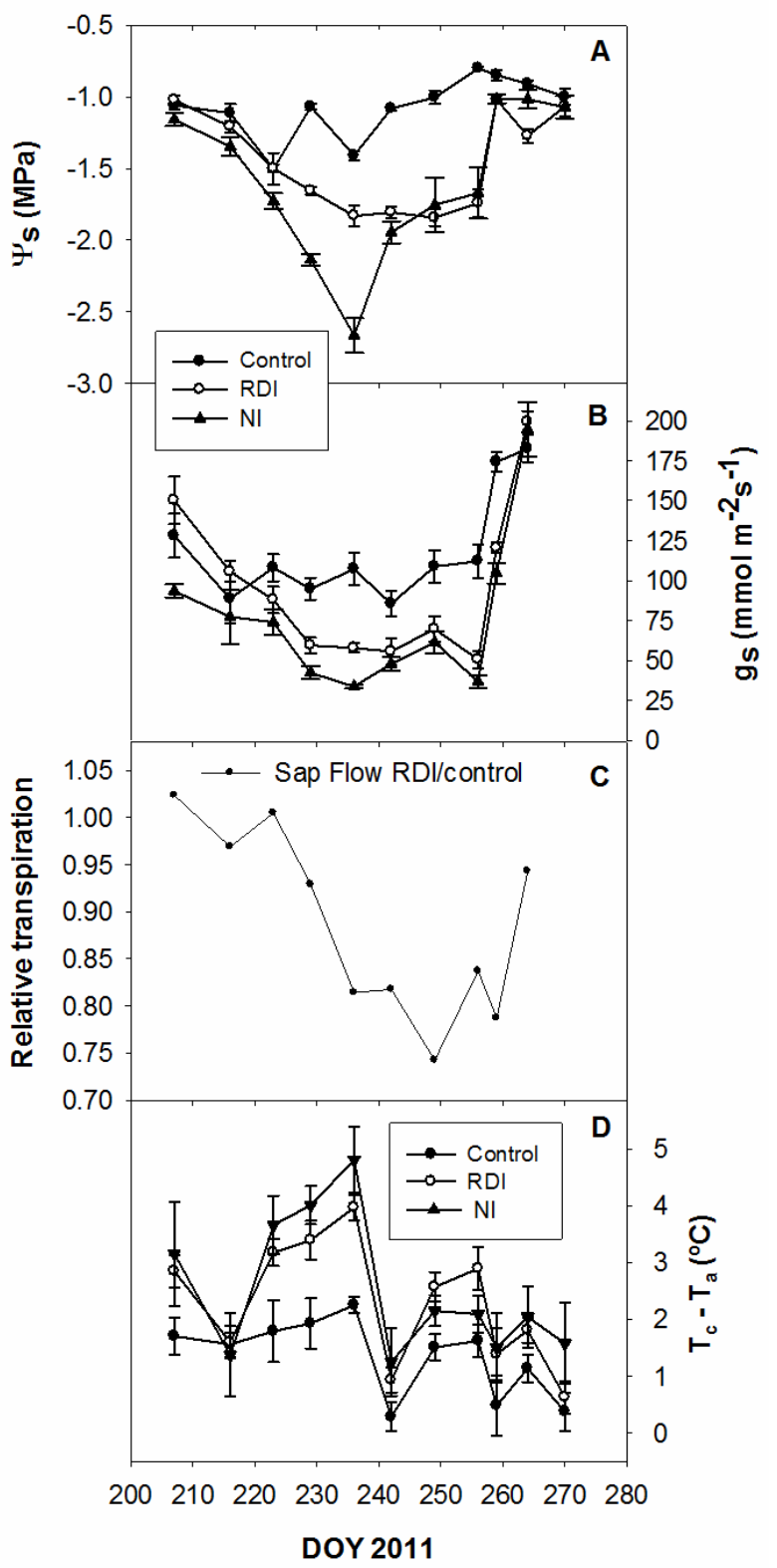

Figure 36 Evolution of $\Psi_{s}(A), g_{s}(B)$, relative transpiration (C) and $T_{c}-T_{a}$ (D) throughout the experiment. 

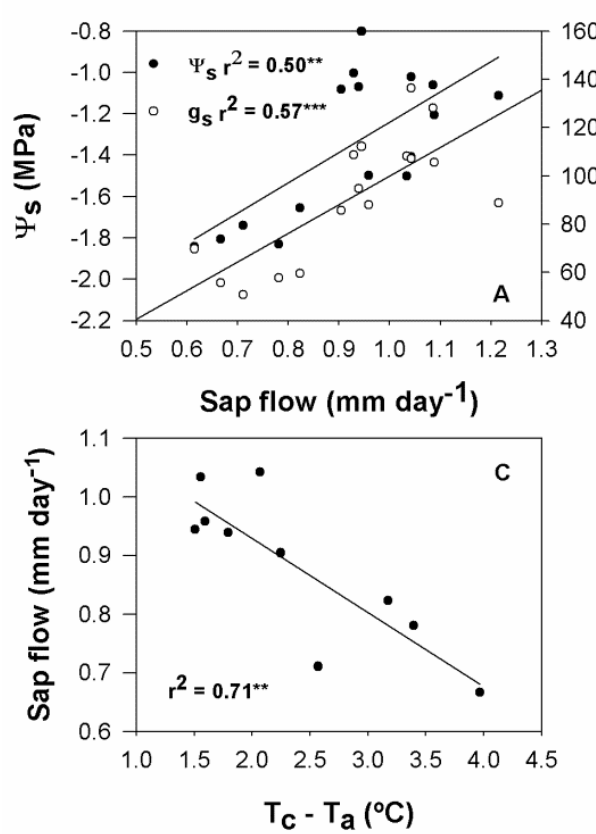
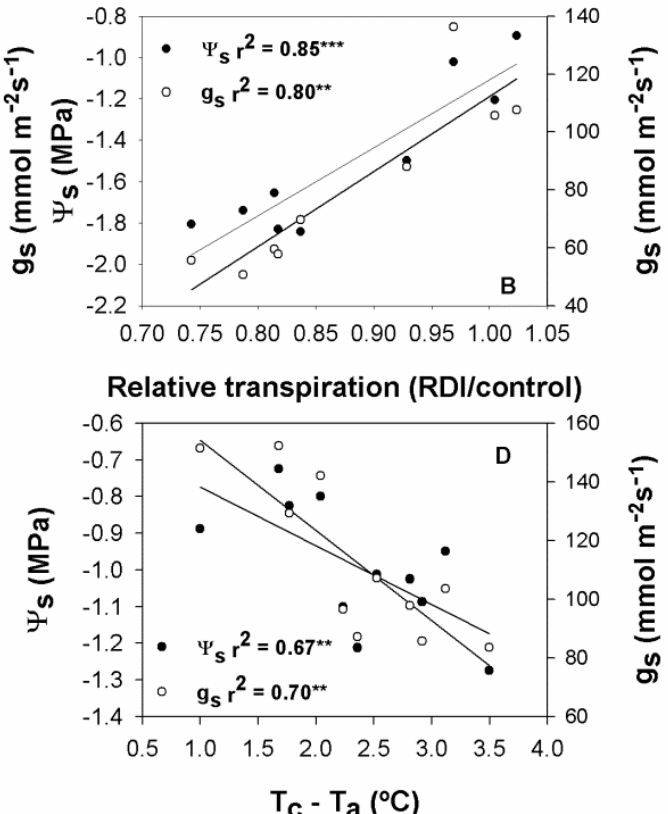

Figure 37 A: Relationships between stem water potential $\left(\Psi_{\mathrm{s}}\right)$ and stomatal conductance $\left(\mathrm{g}_{\mathrm{s}}\right)$ with the absolute sap flow values; B: Relationships between $\Psi_{\mathrm{s}}$ and $g_{s}$ with the relative transpiration; $C$ : Relationships between $T_{c}-T_{a}$ and sap flow; D: Relationships between $\mathrm{T}_{\mathrm{c}}-\mathrm{T}_{\mathrm{a}}$ and $\Psi_{\mathrm{s}}$ and $\mathrm{g}_{\mathrm{s}}$.

$\mathrm{T}_{\mathrm{c}}$ values obtained from thermal images were also in agreement with the evolution of $\Psi_{\mathrm{s}}$. RDI and NI trees had higher $\mathrm{T}_{\mathrm{c}}$ values than control trees during the period of water restrictions (Figure 36D). The maximum differences in $\mathrm{T}_{\mathrm{c}}\left(2.6^{\circ} \mathrm{C}\right)$ were detected between control and NI trees on DOY 236, which was the day with the highest differences in plant water status between treatments as indicated by the $\Psi_{\mathrm{s}}$ and $\mathrm{g}_{\mathrm{s}}$ measurements 
Results

(Figure 36A). For this day, RDI trees were less stressed than the NI ones and consequently the difference in temperature compare to the control trees was lower $\left(+1.7^{\circ} \mathrm{C}\right)$.

A significant relationship was found between $T_{c}-T_{a}$ and the absolute values of sap flow in days with values of VPD lower than $3 \mathrm{kPa}$ (Figure 37C). $T_{c}-T_{a}$ was also well related with $\Psi_{s}$ and $g_{s}$ measurements in those individual days where $\Psi_{\mathrm{s}}$ differences between treatments were higher than 1 MPa (Table 26) and when data for each individual tree was averaged for the period of water restrictions (Figure 37D). However, the relationship observed was poorer, although still significant, for the data of the entire experimental period (Figure 38A)

The good relationships observed for individual days when $T_{c}$ was obtained from thermal imaging were in contrast with the results obtained when $T_{c}$ was obtained from the IRTs. $T_{c}$ values registered at solar midday by the IRTs, when $\Psi_{\mathrm{s}}$ and $\mathrm{g}_{\mathrm{s}}$ measurements took place, were poorly related to them on any single day of measurement (Table 26). Only when data were grouped by treatments, a significant relationship between $\Psi_{\mathrm{s}}$ and $\left(\mathrm{T}_{\mathrm{c}}-\mathrm{T}_{\mathrm{a}}\right)$ was observed in the RDI treatment $\left(r^{2}=0.68 * *\right)$. However, no significant relationship was observed for the control neither for NI trees despite the fact that this latter treatment reached the lowest values of $\Psi_{\mathrm{s}}$ (Figure 38B).

Average values of $T_{c}-T_{a}, \Psi_{s}$ and $g_{s}$ for the period of water restrictions were significantly correlated with the final fruit weight obtained at harvest (Table 27). $T_{c}$ obtained from the thermographic camera had the 
Results

highest $\mathrm{r}^{2}$ followed by $\Psi_{\mathrm{s}}$ and $\mathrm{g}_{\mathrm{s}}\left(\mathrm{r}^{2}=0.72^{* *}, 0.57^{* *}\right.$ and $0.41^{*}$, respectively). $T_{c}$ obtained from the IRTs was not significantly related with the final fruit weight.

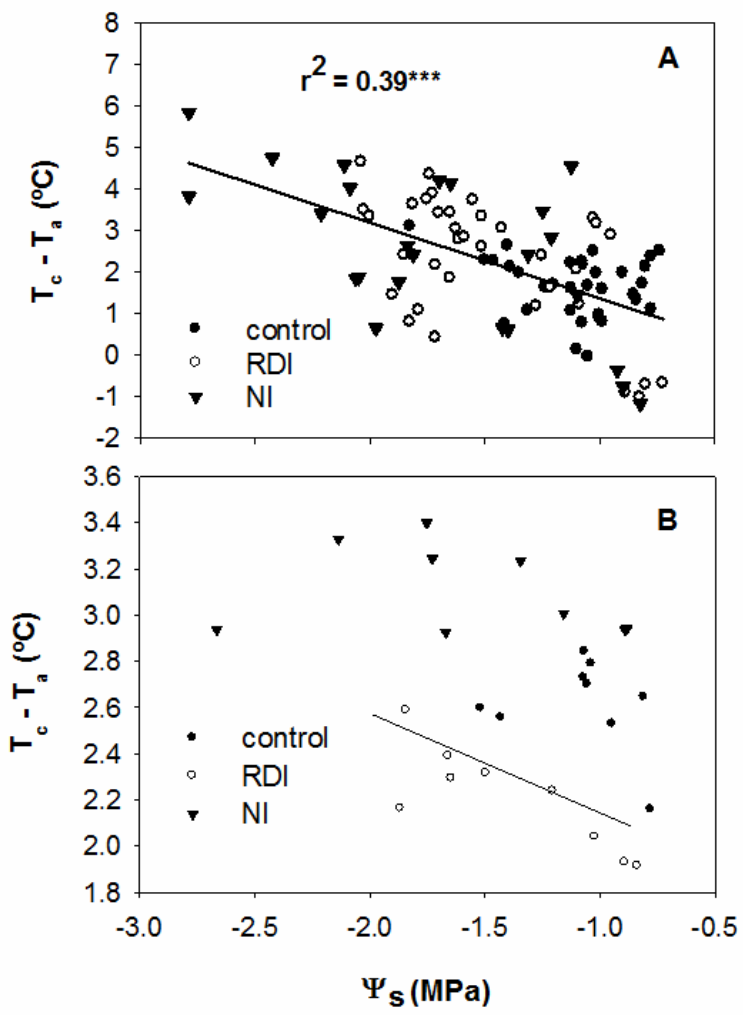

Figure 38 Relationship obtained between stem water potential $\left(\Psi_{\mathrm{s}}\right)$ and canopy temperature minus air temperature $\left(T_{c}-T_{a}\right)$ for each treatment when $T_{c}$ was obtained by thermal imaging (A; data from all the measurements pooled together, $n=93)$ and by fixed infrared thermometer sensors $\left(B, r^{2}\right.$ for the RDI treatment was $\left.0.68^{* *}\right)$. 
Results

Table 27 Relationships between fruit weight (FW) at harvest and the average value of the different water stress indicators: stem water potential $\left(\Psi_{\mathrm{s}}\right)$, canopy temperature normalized by air temperature $\left(T_{c}-T_{a}\right)$, sap flow measurements and stomatal conductance $\left(g_{s}\right)$.

\begin{tabular}{lcc}
\hline & $\mathbf{R}^{2}$ & $\mathbf{n}$ \\
FW vs. $\Psi_{\mathbf{s}}$ & $0.57 * *$ & 11 \\
FW vs. $\left(\mathbf{T}_{\mathbf{c}}-\mathbf{T}_{\mathbf{a}}\right)$ (Thermal imagery) & $0.72^{* *}$ & 11 \\
FW vs. $\mathbf{g}_{\mathrm{s}}$ & $0.41^{*}$ & 11 \\
FW vs. $\left(\mathbf{T}_{\mathbf{c}}-\mathbf{T}_{\mathbf{a}}\right)($ IRTs) & 0.26 & 9 \\
FW vs. Sap flow & 0.34 & 4 \\
\hline
\end{tabular}


4 Discussion

133 


\subsection{RDI strategies in commercial 'Clementina de Nules' and 'Navel Lane Late' groves}

The present results obtained confirm previous research by GonzálezAltozano and Castel (1999) that showed that summer is a suitable period for applying water restrictions. However, it is important to take into account that the final effect of RDI on yield and fruit size distribution depends on both the degree and duration of the plant water stress.

In 'Clementina de Nules' the moderate plant water stress applied in the RDI-1 treatment did not negatively affect yield nor average fruit weight over the five seasons. Nonetheless, a more severe plant water stress (RDI-2 treatment) impaired tree performance reducing the economic return. The duration of water restrictions imposed is a crucial determinant of plant responses to RDI (Ginestar and Castel, 1996). In our study in 'Clementina de Nules', although seasonal water savings achieved in 2008 respect to control (22\% and $24 \%$ in RDI-1 and RDI-2, respectively) were similar to that achieved in the RDI-1 treatment in the first year of study (20\%), the effect on yield was different. This was probably because in 2008 water restrictions lasted until the end of September, 19 days more than in 2007 (Table 5). This longer period of RDI resulted in a higher value for the $S_{\psi}$ in 2008 than in 2007, surpassing the value of $64 \mathrm{MPa}^{*}$ day that appears as a recommendable threshold for water stress applied during summer (i.e. during the second linear phase of fruit growth) in 'Clementina de Nules' since it was the highest value observed in the RDI-1 treatment that did not reduce fruit weight. 
Discussion

In 'Navel Lane Late', the same RDI-1 strategy applied successfully in the 'Clementina de Nules' grove led to a statistically significant reduction in fruit weight (- $9 \%$ for the average of the four seasons) though it did not reduce yield (Table 13). This is somewhat surprising considering that 'Navel Lane Late' is a late-season-maturing variety (harvested in MarchApril) and therefore, fruit had more time than those of 'Clementina de Nules' (harvested in December) for a possible compensatory fruit growth after resuming irrigation to full dosage, as observed in grapefruit by Cohen and Goell (1988) and in 'Clementina' by González-Altozano and Castel (2000). The reasons for this lack of compensatory fruit growth and apparent higher sensitivity to water stress of the 'Navel Lane Late' cultivar are not completely clear. This could perhaps be due to the fact that 'Navel Lane Late' fruit achieved $81 \%$ of its final size at the end of the period of water restrictions when irrigation was resumed to normal dose whilst 'Clementina de Nules', for instance, achieves only about $71 \%$. Also it may be noted that temperature during the extra months of January to March in Navel Lane Late can be sufficiently low to limit the possible fruit growth compensations responses.

The present results demonstrate that it is not always straightforward to extrapolate RDI results among varieties and that local field experiments need to be conducted before suggesting the widespread adoption of RDI strategies to commercial situations. Indeed, the significant reduction in yield obtained in 2008 suggests that the threshold value of $\Psi_{\mathrm{s}}(-1.3$ to $-1.5 \mathrm{MPa})$ suitable for summer RDI strategies in 'Clementina de Nules' is not appropriate for 'Navel Lane Late'. 
Discussion

For the application of summer RDI on 'Navel Lane Late' we suggest threshold $\Psi_{\mathrm{s}}$ values of -1.2 to $-1.3 \mathrm{MPa}$. In addition, $70 \mathrm{MPa}$ day is the recommended $S_{\psi}$ threshold since this was the highest value observed in the RDI treatments that did not lead to a reduction in yield.

As reported in 'Clementina de Nules', results obtained in 'Navel Lane Late' trees indicate that the impact of the RDI treatments imposed on tree yield depends on the duration and degree of severity of the plant water deficit rather than just on the reduction in water application. In fact, similar reductions in water application were obtained in 2008 in both RDI treatments and in 2009 in the RDI-1. However, in 2009 when water stress integral reached by the RDI-1 treatment was of only 64.2 MPa*day, yield was not reduced by the deficit irrigation applied, while in 2008, 88.0 and 94.3 $\mathrm{MPa}^{*}$ day in the RDI-1 and RDI-2 treatments, respectively, significantly reduced yield with respect to the control. This fact indicates that when deficit irrigation is applied it is necessary to measure the plant water stress in order to determine the real impact that the imposed water restrictions have on plant water status. In this sense, it can be speculated that in 2008 RDI trees suffered more stress than in 2009 because the tree crop level (i.e. number of fruit per tree) in the second experimental season (2008) was higher. Particularly in stone fruit trees it has been well documented that tree crop level is a determinant factor affecting plant water status (Naor, 2006). In citrus trees, the possible interactive effects between deficit irrigation and tree crop level has not been comprehensively studied, because thinning is not a normal cultural practice. Our results in 'Navel Lane Late' might then indicate that further studies should be conducted to more 
Discussion

precisely define the effects of crop level and deficit irrigation in a multiple factor experiment with both factors varying within the same season.

Similarly to other RDI experiments conducted in citrus trees (Hutton et al., 2007; García-Tejero et al., 2010), deficit irrigation applied during the second phase of fruit growth increased fruit TSS and TA in both citrus species. In the 'Navel Lane Late' experiment, the effects of RDI on fruit TA were more pronounced that those observed for TSS. This fact suggests that plant water stress led to an increased synthesis of organic acids as an osmotic adjustment mechanism (Yakushiji et al., 1996; Hockema and Etxeberria, 2001; Barry et al., 2004) rather than a concentration effect due to smaller fruit. Apart from the physiological reasons for this higher increase in TA than in TSS brought about by water stress, this fact caused a decrease in the maturity index of the RDI treatments. This can be considered as a positive outcome since a delay in fruit ripening has commercial advantages in late-season-maturing cultivars like 'Navel Lane Late' that often increase in market price when they are picked later in the season. Previous studies on 'Clementina de Nules' have also reported this drop of the maturity index in deficit irrigated trees when irrigation was withheld from mid-June to early October (Navarro et al., 2008). However, this effect was not observed even in the RDI-2 treatment in our experiment with 'Clementina de Nules' in which trees were irrigated at $30-40 \%$ of ET $_{c}$ from July to mid-September. This different behavior of the maturity index in response to deficit irrigation suggests that it may depend on the intensity of the stress reached by trees. 
Discussion

The growth reduction in RDI trees can be considered also a positive effect since it diminishes the competition between vegetative and reproductive growth, increasing tree efficiency. Moreover, as other studies in 'Navel Lane Late' have reported (Pérez-Pérez et al., 2010), this growth reduction can represent an important diminution in the variable and fixed operating costs associated with the crop management as pruning or water and energy for pumping. The reduction of these costs could compensate in some instances the possible profit reduction due to the smaller fruit size.

We now consider that the only limitation for using RDI is the fact that plant water stress needs to be periodically monitored and automatic and reliable methods are needed to replace the stem water potential as a water stress indicator. This is the reason why an important effort was conducted to explore the feasibility of using several tools for continuously and remotely monitoring plant water status.

\subsection{Sap flow as plant water stress indicator}

In both orchards, sap flow measurements notably underestimated transpiration compared with estimates calculated as function of the canopy ground cover according to Castel (2000) (Table 13), as well as compared to transpiration determined by canopy gas exchange measurements with portable chambers reported elsewhere (Ballester et al., 2011). In 'Clementina de Nules' trees, the underestimation in tree transpiration was more evident for type 2 gauges (thermocouple sensors at 10, 17, 26 and 38 $\mathrm{mm}$ of radial depth) than for type 1 (sensors at 5, 12, 21, $32 \mathrm{~mm}$ ). This was because for a given xylem depth lower sap flow was obtained in type 2 than 
Discussion

in type 1 gauges and not because of the different sensors depth (Figure 27). This confirms that in addition to the radial variation in sap flow, in citrus trees there is also an important azimuthal variation and the estimated flux values can vary substantially depending on the location of the temperature sensing points. Similar trends were also obtained in olive trees by Nadezhdina et al. (2007) and by Lopez-Bernal et al. (2010), who reported high azimuthal variation in sap flow values $(\mathrm{CV}=54.1 \%)$. Lopez-Bernal and co-workers had deviations above $10 \%$ in tree transpiration when fewer than six probes were used. Other studies in olive trees (Fernández et al., 2001), however, suggest that only two to four probes per trunk would be enough to obtain good estimates of tree transpiration.

The general underestimation in tree transpiration obtained in our study in all the cases could be in part consequence of using a low number of probes per tree but also because the "actual" unknown wound size might have been higher than the value used here $(2.4 \mathrm{~mm})$ which is the suggested value for citrus trees based on direct calibrations (Fernández et al., 2006).

Sap flow measurements allowed quantifying the transpiration reduction in trees under water restrictions. Water savings during the RDI period close to $50 \%$ in both species caused a transpiration reduction of only $15 \%$ in 'Navel Lane Late' and 20\% in 'Clementina de Nules' trees. This implies that the net transpiration reduction obtained was much lower than the actual water application reduction: the difference thus is water extracted from the soil reservoir. Since most of the RDI trials previously conducted (e.g. revisions by Naor, 2006 and Ruíz-Sánchez et al., 2010) only 
Discussion

determined irrigation water savings achieved, our results suggest that the potential savings in consumptive tree water use can be less considerable than just the irrigation water saving itself. As the difference between the orchard water use (transpiration + evaporation from the soil) and the water applied by irrigation is drawn from the soil water storage, in years when the precipitations do not refill completely the soil water capacity this difference can be reduced, and a RDI strategy that has been proven successful in wetter years could induce more severe water stress and fail. This is a risk to be taken into account in climates with high variability in the amount of cool season precipitations; further research is required to reduce this risk by dynamically modifying the RDI strategies depending on the soil water storage available at the onset of the irrigation period.

Among the different water stress indicators studied here, RT followed closely the evolution of $\Psi_{\mathrm{s}}$ showing in all cases a good correlation. This correlation, however, was different between years, species and gauge types in the 'Clementina de Nules' orchard, in which the type 2 gauges had better correlations than type 1 ones (Figure 40). This implies that the relationship between $\mathrm{RT}$ and $\Psi_{\mathrm{s}}$ may not be unique across seasons, and site specific calibrations are needed before attempting to predict $\Psi_{\mathrm{s}}$ from RT. In addition, it should also be noted that previous research in apple and grapevines has shown that the sensitivity of the heat-pulse compensation technique can be low in cases of high transpiration (Dragoni et al., 2005, 2006). Dragoni and co-workers showed that in occasions sap flow values did not increase more when a certain transpiration value was reached. This 
Discussion

implies that the use of RT as a water stress indicator has to be done carefully, since actual values of RT could be affected if the relationship between sap flow measured and the actual canopy transpiration diverges from linearity.

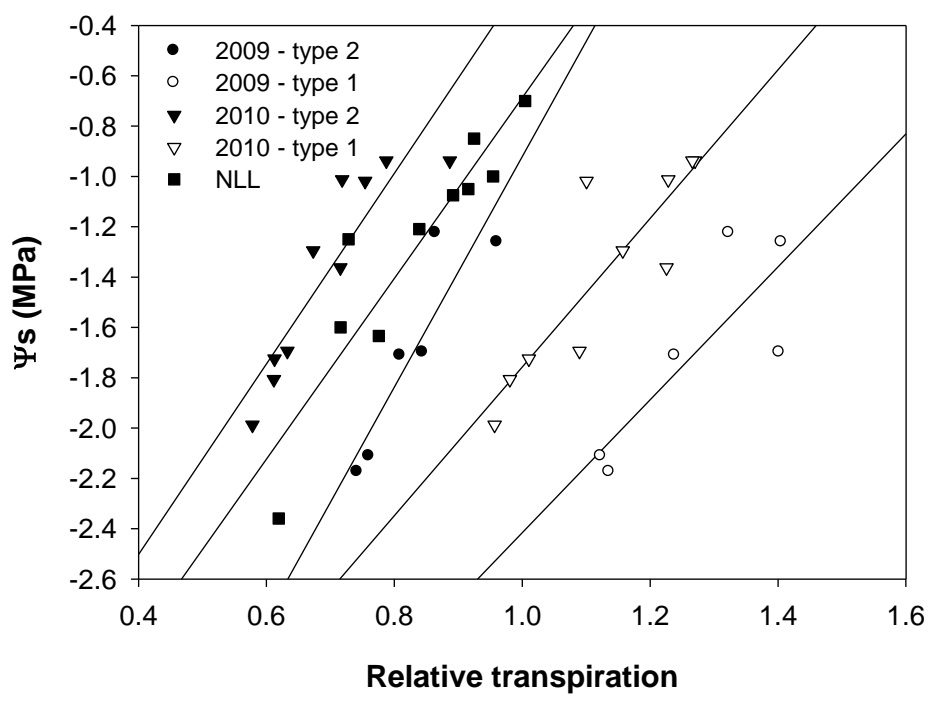

Figure 40 Relationships between midday stem water potential $\left(\Psi_{\mathrm{s}}\right)$ and relative transpiration for 'Clementina de Nules' in 2009 (type1 gauges $\mathrm{r}^{2}=0.68^{*}$, type2 gauges $r^{2}=0.81^{*}$ ) and in 2010 (type1 gauges $r^{2}=0.77^{* * *}$, type2 gauges $\left.r^{2}=0.82 * * *\right)$, and for 'Navel Lane Late' $\left(r^{2}=0.84 * * *\right)$. Asterisks indicate the level of significance of the linear regressions.

The small lag in the sap flow recovery respect to $\Psi_{\mathrm{s}}$ when irrigation was resumed to normal dose observed in 2010 in both species, was likely due to an after-effect of water stress on stomatal behaviour as reported in other studies on citrus trees (Ortuño et al., 2007). Results obtained in 2009 
Discussion

also showed that increases in RT can occur as a consequence of a sudden decrease in the evaporative demand in spite of $\Psi_{\mathrm{s}}$ in RDI trees being still low (around -2.0 MPa in our experiment). This confirm the general idea that under low evaporative demand, plants with mild water restrictions are still able to transpire at a rate close to that of well-watered plants (van den Honert, 1948; Denmead and Shaw, 1962) implying that plant responses to soil water limitations are dependent on the evaporative demand. Interestingly, we also observed that Tm, particularly for 'Navel Lane Late', was climate dependent showing a negative relationship with VPD (Figure 26), similar to the results of Dragoni et al. (2005) in apple. In our case, however, well-watered plants reduced transpiration most likely due to a stomatal regulation in response to air dryness levels as previously reported in citrus (Syvertsen and Lloyd, 1994; Oguntunde et al., 2007; Villalobos et al., 2009) and in other crops (Ferreira et al., 1992 in tomato; Moriana et al., 2002 in olive). This Tm fluctuation in response to VPD changes reinforces the idea that for optimizing irrigation management, scheduling should be based on monitoring the soil-plant-atmosphere continuum. Irrigation scheduling based on the FAO model, which uses the $\mathrm{ET}_{\mathrm{o}}$ and $\mathrm{K}_{\mathrm{c}}$ approach, might lead to important deviations from the actual plant water needs. Indeed, as other authors have reported (Annandale and Stockle, 1994; Dragoni et al., 2005), the non-linearity presented in figure 25 (transpiration of well-watered trees versus $\mathrm{ET}_{\mathrm{o}}$ ) questions whether short dense crops, like grass, should be used as a reference for tall discontinuous canopies in climates where VPD can exhibit large variations. A second interpretation of the non-linearity of figure 25 could also be given. Our experimental trees 
Discussion

were drip irrigated: the volume of wetted soil a plant can reach is thus limited. Roots, in these conditions, tend to increase noticeably their spatial density, but their capacity to extract water may not meet the requirements under days of very high evaporative demand, not because not enough water is present in the soil, but because the root density is insufficient for that given day.

Although in 'Clementina de Nules' trees equipped with type 1 gauges, some differences in sap flow radial pattern were found between well-watered and RDI trees, a strong conclusion cannot be taken from this experiment since no differences were found in trees instrumented with the type 2 gauges nor in the NLL ones.

With regard to the N/D index, the values found in 'Clementina de Nules' and 'Navel Lane Late' (5-17\%) are comparable with those reported in other species (Dalley and Phillips, 2006). The highest values of N/D were obtained in days with low VPD and with some rain, in which daily transpiration decreased, following days with high transpiration. In any case, from our data it is not possible to infer which part of the nocturnal sap flow detected was due to plant transpiration and which due to water redistribution within the tree tissues. In this sense, Dalley and Phillips (2006) observed in red oak and red maple, a low sensitivity of sap flow to high nighttime values of VPD (close to $1.0 \mathrm{kPa}$ ) suggesting that sap flow values measured at nighttime likely represented the recharge of depleted water stores within the trees. In our experiment, 'Navel Lane Late' and 'Clementina de Nules' control trees had similar N/D values to RDI trees on average for the period 
Discussion

of water restrictions (13\% in 'Clementina de Nules' RDI trees and $10 \%$ in the control ones and 10 and 7\% in 'Navel Lane Late' control and RDI trees, respectively). However, in agreement with López-Bernal et al. (2010), RDI trees of both species showed an increase of N/D during the period of water restrictions as $\Psi_{\mathrm{s}}$ decreased. The relationship between N/D and $\Psi_{\mathrm{s}}$ (Figure 28) confirms the hypothesis that N/D could be used to predict $\Psi_{\mathrm{s}}$ in citrus trees. However, more research would be needed to assess whether N/D could be used to determine the plant water status in other woody perennial species before concluding that $\mathrm{N} / \mathrm{D}$ is a reliable and robust water status indicator.

\subsection{Thermal imaging for plant water stress detection in citrus and persimmon trees}

4.3.1 Canopy temperature sensitivity to water stress in citrus and persimmon trees

The canopy temperature of persimmon trees showed great responsiveness to variations in plant water status. The maximum $\Delta \mathrm{T}_{\mathrm{c}}$ observed in this species was of $4.4^{\circ} \mathrm{C}$, which occurred when WS trees had $\Psi_{\mathrm{s}}$ values 1.1 MPa more negative than the control ones. In pistachio trees, another woody crop with large leaves like persimmon, Testi et al. (2008) reported $\mathrm{T}_{\mathrm{c}}$ differences of as much as $6.0^{\circ} \mathrm{C}$ between well-irrigated and stressed trees when nadir-view radiometric temperature was measured with infrared thermometers. 
Discussion

Among the water stress indicators evaluated in persimmon trees, $T_{c}$ was clearly the most sensitive mainly as a consequence of the much lower tree-to-tree variability compared to $\Psi_{\mathrm{s}}$ and $\mathrm{g}_{\mathrm{s}}$ (Table 24). The use of thermal imaging along with an automated program to process the images allowed for a large number of leaves per tree to be measured. $\Psi_{\mathrm{s}}$ and $\mathrm{g}_{\mathrm{s}}$, however, are usually determined by measuring a small number of leaves per tree (in this study two for $\Psi_{\mathrm{s}}$ and five for $\mathrm{g}_{\mathrm{s}}$ ), which can increase the variability due to the important heterogeneity found in the intra-crown variation of leaf water status and particularly of stomatal conductance as a consequence of differences in hydraulic resistance among different parts of the tree (González-Dugo et al., 2012).

In the experiment with citrus, $\mathrm{T}_{\mathrm{c}}$ response to water stress was different for each experimental season. In 2009, $\mathrm{T}_{\mathrm{c}}$ did not allow detecting the existing differences in plant water status, but in 2010, water-stressed trees had significantly higher $T_{c}$ than the control ones with differences of up to $1.7^{\circ} \mathrm{C}$. As a consequence, in this second experimental season, $\mathrm{T}_{\mathrm{c}}$ was the best water stress indicator studied while $\Psi_{\mathrm{s}}$ and CWSI showed similar sensitivity between them. In any case, the temperature differences between well-watered and water-stressed trees reported here are low compared to another study in sweet orange trees (García-Tejero et al., 2011), which reported differences of up to $4.8^{\circ} \mathrm{C}$. However, in García-Tejero et al. (2011) plant water stress reached by deficit irrigated trees was more severe $\left(\Psi_{\mathrm{s}}\right.$ of 2.0 and $-2.4 \mathrm{MPa}$ ) than in the present study in which $\Psi_{\mathrm{s}}$ values reached by the stressed trees were more moderate and in the range of what it is 
Discussion

suggested for application of regulated deficit irrigation in commercial orchards as has been discussed in previous sections. Our results allowed then to test the feasibility of using canopy temperature for measuring plant water status under moderate stress levels which can be more frequently applied in commercial orchards. In olive trees, another plant with small leaves like citrus, Sepulcre-Cantó et al. (2009) found similar differences in $\mathrm{T}_{\mathrm{c}}$ between irrigated and non-irrigated trees which reached values of up to $2.0^{\circ} \mathrm{C}$.

Although $\mathrm{g}_{\mathrm{s}}$ was not measured on our citrus trees during this experiment, it is well known that even well-watered trees respond to air dryness with partial stomatal closure and therefore with a reduction in transpiration (Oguntunde et al., 2007; Villalobos et al., 2009). In this same plot, sap flow determinations showed that transpiration of well-watered trees was weather dependent and had a negative relationship with VPD, i.e., days with high VPD corresponded with low transpiration values. In our experiment in citrus during 2009, in which there were no significant differences in $T_{c}$ between treatments, the days in which thermal images were taken had higher VPD values than those of 2010. Furthermore, in 2010 $\mathrm{T}_{\mathrm{c}}$ was significantly different between treatments for all the days except on DOY 238 which had a VPD value (4.5 kPa) similar to those registered in the first experimental season (Table 17). The possible reduction in transpiration in control trees during the days with high evaporative demand along with the low increase in $T_{c}$ observed in water-stressed trees respect to the control ones for the two experimental seasons, could explain the lack of consistence 
Discussion

in the response of canopy temperature to water stress observed between years.

The different effect that plant water stress had in canopy temperature between citrus and persimmon trees can be explained considering two physiological differences between crops. On one hand, persimmon trees have larger leaf size than citrus. Leaf size and wind speed are the main factors affecting the air boundary layer next to a leaf, which influence heat exchange and hence the temperature of the leaf. Under conditions of low wind speeds $\left(<10 \mathrm{~m} \mathrm{~s}^{-1}\right)$, larger leaf size leads to thicker air boundary layers, less convective heat loss, and consequently to greater differences from air temperature than smaller leaves (Nobel, 2009). Thus, under a certain stomatal closure level, crops with larger leaves like persimmon will tend to raise its temperature more than plants with smaller leaves like citrus. On the other hand, we should consider the effect that other factors, apart from soil water deficit, might have on stomatal closure. Contrarily to the already mentioned stomatal closure in response to VPD in citrus trees (Oguntunde et al., 2007; Villalobos et al., 2009), in the experiment performed in the persimmon orchard, a positive relationship between $\mathrm{g}_{\mathrm{s}}$ and VPD $\left(0.51^{* *}\right)$ was observed. This feature of persimmon allowed that even in days with high evaporative demand (like DOY 239 with VPD of $6.9 \mathrm{kPa}$ ) $\mathrm{T}_{\mathrm{c}}$ was well correlated with $\Psi_{\mathrm{s}}$. The relationship found between $\mathrm{T}_{\mathrm{c}}$ and $\Psi_{\mathrm{s}}$ for this day, when images were taken from a crane, was best-fitted by a polynomial curve (Figure 30), indicating that lower $\Psi_{\mathrm{s}}$ values corresponded with higher $\mathrm{T}_{\mathrm{c}}$ values up to $-2.2 \mathrm{MPa}$, point in which the canopy temperature stopped increasing. 
Discussion

\subsubsection{Comparison of different canopy temperature indexes}

In persimmon trees, both frontal (sunlit or shaded) and zenithal images clearly detected the higher $\mathrm{T}_{\mathrm{c}}-\mathrm{T}_{\mathrm{a}}$ of WS trees compared with the control ones. In this crop, either side of the canopy was suitable for measuring the temperature. In citrus trees, however, the results suggest that images obtained from the leaves most directly exposed to the solar radiation are more appropriate than frontal images to detect plant water stress. In fact, in a day with high evaporative demand during the second experimental season (DOY 238) when frontal images did not detect any differences in $T_{c}$ between RDI-2 and control trees, zenithal thermal images detected significant differences between them (Figure 34B,C). In addition, the highest correlations between $T_{c}-T_{a}$ and $\Psi_{s}$ were obtained when pictures were taken from $1 \mathrm{~m}$ above the canopies (Table 17).

In this two-year study, images were taken on each experimental season at least in five different days. For both orchards $\mathrm{T}_{\mathrm{c}}-\mathrm{T}_{\mathrm{a}}$ and $\Psi_{\mathrm{s}}$ or $\mathrm{g}_{\mathrm{s}}$ were well correlated in some particular days. The highest correlations were always those between $T_{c}-T_{a}$ and $\Psi_{s}$ which had a coefficient of correlation of up to 0.90 and 0.56 for persimmon and citrus trees, respectively (Tables 21 and 22). The correlations obtained in particular days for citrus between $\mathrm{T}_{\mathrm{c}}-\mathrm{T}_{\mathrm{a}}$ and $\Psi_{\mathrm{s}}$ when images were taken from $1 \mathrm{~m}$ above the canopies (Table 22), are similar to those reported by Sepulcre-Cantó et al. (2006) in olive trees, in which canopy temperature was measured with fixed infrared sensors installed $1 \mathrm{~m}$ above the tree crowns. However, when data from several days were pooled together, the relationships between $T_{c}-T_{a}$ and $\Psi_{s}$ 
Discussion

or $g_{s}$ were not tight suggesting that other environmental and endogenous factors also affected the relationships between canopy temperature and plant water status. Similarly, in citrus trees day-to-day differences in CWSI were not tightly related with $\Psi_{\mathrm{s}}$ measurements. The CWSI normalizes $\mathrm{T}_{\mathrm{c}}$ measurements taking into account day-to-day differences in environmental conditions, but it does not consider possible on-tree factors affecting stomatal conductance such as seasonal changes in the sink/source relationships and in leaf age.

The relationships between $T_{c}-T_{a}$ and $\Psi_{s}$ observed in persimmon for each experimental season (Figure 31) and in citrus for the second one (Figure 35), are similar to those reported for olive trees by Sepulcre-Cantó et al. (2006) who obtained relationships with $\mathrm{r}^{2}$ ranging between 0.25 and 0.62. Nevertheless, our relationships show a generally lower fit than those reported by other authors in peach (Wang and Gartung, 2010), with $\mathrm{r}^{2}$ of 0.70 , or sweet orange (García-Tejero et al., 2011), with $r^{2}$ of 0.75 . These authors also found lower regression coefficients between $T_{c}-T_{a}$ and $g_{s}$ suggesting that this fact could be due to the difficulty of relating the average temperature of multiple differently-oriented leaves with stomatal conductance of individual ones. In our experiment, however, there were no significant relationships between these parameters.

Finally, an effort was made to explore if the intra-crown temperature variability could be also used for water stress detection. Recently, GonzálezDugo et al. (2012) in almond trees found that this indicator was mainly related with differences in soil water content, rooting depth and irrigation 
Discussion

distribution; while the environmental conditions did not affect much the seasonal variation of this indicator. However, in our experiment in citrus and persimmon trees the intra-crown temperature variability was not different among irrigation treatments. Thus this indicator does not seem useful to detect plant water stress in persimmon and citrus trees. Our results are more in agreement with those reported in grapevines by Möller et al. (2007) or Grant et al. (2007), who also found that temperature variability within a canopy was not different between well-watered and water-stressed grapevines. It seems then that the usefulness of the intra-crown temperature variability index for plant water stress detection might be different according to the plant species. An analysis of the absolute values of standard deviation shows that species with apparent low sensitivity of intra-crown temperature variability have higher absolute values $\left(1.6-3.8{ }^{\circ} \mathrm{C}\right.$ for grapevines, $2.1-2.4{ }^{\circ} \mathrm{C}$ for persimmon and $1.1-1.9^{\circ} \mathrm{C}$ for citrus) than almond trees in which the standard deviation values of canopy temperature varied from 0.6 to $1.8{ }^{\circ} \mathrm{C}$. It is difficult to find an explanation for this different behaviour among species since many physiological responses such as stomatal patchiness, leaf angle distribution, xylem cavitation and branch or shoot autonomy behaviour, among others, can determine intra-crown temperature variability when soil water limitations are imposed.

\subsection{Performance of different water stress indicators for citrus trees}

The results obtained in the experiment 5 related with sap flow and $\mathrm{T}_{\mathrm{c}}$ measurements carried out using a thermographic camera were in agreement 
Discussion

with those reported in the previous experiments. Indeed, both methods allowed detecting plant water stress.

Figure 37C depicts the RT decrease during the period of water restrictions which closely followed the trends of $\Psi_{\mathrm{s}}$ and $\mathrm{g}_{\mathrm{s}}$ observed in RDI trees. These results confirm previous findings in olive trees (Fernández et al., 2007; 2008). These authors also suggested that RT can be successfully used for water stress detection and even for automatic irrigation scheduling. The relationship observed between RT and $\Psi_{\mathrm{s}}$ in the present experiment $\left(\mathrm{r}^{2}\right.$ $=0.85$ ), was similar although slightly tighter than that reported by Ortuño et al. (2006) in an experiment with lemon, where the water stress was more severe and trees reached $\Psi_{\mathrm{s}}$ values close to $-3 \mathrm{MPa}\left(\mathrm{r}^{2}=0.95\right)$.

$\mathrm{T}_{\mathrm{c}}$ values obtained from thermal images were also in agreement with the evolution of $\Psi_{\mathrm{s}} .2 .6^{\circ} \mathrm{C}$ was the maximum difference in temperature registered between control and NI trees, which reached a $\Psi_{\mathrm{s}}$ value of -2.7 $\mathrm{MPa}$. In RDI trees, $\Psi_{\mathrm{s}}$ dropped to $-1.8 \mathrm{MPa}$ and the temperature difference with control trees was of $+1.7^{\circ} \mathrm{C}$, the same difference detected between 'Navel Lane Late' control and severe water-stressed trees in the experiment 4. $T_{c}-T_{a}$ differences observed between water-stressed and well-watered trees on DOY 236, were lower than those predicted by a leaf energy balance model, as the one developed by Prof. Kevin $\mathrm{Tu}$ (http://landflux.org/Tools.php), using the corresponding leaf (shape, dimensions, absorptance, angle from the horizontal, emissivity and stomatal resistance) and environmental parameters (short wave radiation, relative humidity, wind speed and air temperature). In our experiment we did not 
Discussion

measured the leaf angle from the horizontal. However, initially we used a value of $35^{\circ}$, characteristic for well-watered citrus trees (Cohen and Fuchs, 1987). We can then speculate that the differences between measured and model predicted values could be explained by a change in the leaf angle of water-stressed trees that allow them to intercept lower solar radiation. In fact, the $T_{c}-T_{a}$ differences of 2.6 and $1.7^{\circ} \mathrm{C}$ observed between NI and RDI trees compared to the control would be equal to the model predictions if leaf angles of $55^{\circ}$ and $49^{\circ}$, respectively, are introduced in the model. Our visual observations indicate that citrus leaves under severe water stress (as in NI trees) tend to roll and also become more erectophylic, corroborating this hypothesis.

For the whole experimental period, $\mathrm{T}_{\mathrm{c}}-\mathrm{T}_{\mathrm{a}}$ was significantly although poorly related with $\Psi_{\mathrm{s}}\left(\mathrm{r}^{2}=0.39^{* * *}\right)$, pointing out the difficulty to use $T_{c}$ measurements in absolute terms as a water stress indicator in citrus. A relatively poor relationship between these parameters was also reported in 'Navel Lane Late' trees under RDI in the experiment $4\left(r^{2}=0.42\right)$, and in 'Powell Navel' oranges and 'Clemenvilla' mandarins $\left(\mathrm{r}^{2}=0.34\right.$; ZarcoTejada et al., 2012) in a study in which $\mathrm{T}_{\mathrm{c}}$ was obtained with a thermal camera from an unmanned aerial vehicle in Seville (Spain). In contrast, other authors (García-Tejero et al., 2011) have reported higher relationships in 'Navelina' deficit irrigated trees $\left(r^{2}=0.75\right)$.

The good relationships observed for individual days when $T_{c}$ was obtained from thermal imaging were in contrast with the results obtained from the IRTs. Daily $T_{c}$ measurements were poorly related with the $\Psi_{\mathrm{s}}$ 
Discussion

evolution. Only when data were pooled together and grouped by treatments $\mathrm{T}_{\mathrm{c}}-\mathrm{T}_{\mathrm{a}}$ was related with $\Psi_{\mathrm{s}}$ in RDI trees although no relationship was found in NI trees, which reached the lowest $\Psi_{\mathrm{s}}$ values. The higher variability and lower target area focused by the IRTs, particularly in the NI treatment, compared with the thermal camera clearly hampered the detection of changes in $T_{c}$ in water-stressed trees with the IRTs. The sample of leaves included in the measurement with the thermal camera was larger than with the IRTs and consequently should be better related with $\Psi_{\mathrm{s}}$ and $\mathrm{g}_{\mathrm{s}}$ measurements. Moreover, thermal images were taken from the sunlit side of the canopies while IRTs were pointing from above. This fact could impair $\mathrm{T}_{\mathrm{c}}$ measurements with the IRTs since they were focused on the most exposed leaves to the solar radiation, but perhaps also on some shaded areas from inside the canopy. The manual and also the automatic processing of the thermal images allows the operator to select the leaves (sunlit or shaded) or even portions of the canopy to be analyzed, avoiding those areas that could introduce significant noise in the results. These facts, highlight the advantage of thermal images as compared to IRTs indicating that methods that integrate a larger number of leaves for the temperature measurements, as in the thermal imaging, are more appropriate than methods that rely only in a few leaves from a specific location of the canopy as occurred with the fixed infrared thermometer sensors.

On the base of a signal to noise ratio, $T_{c}$ was shown in the experiment 4 as a high sensitive water stress indicator for citrus trees due to the much lower tree-to-tree variability compared to other methods like $\Psi_{\mathrm{s}}$ or 
Discussion

$\mathrm{g}_{\mathrm{s}}$. Apart from the sensitivity to water stress, from the agronomical point of view, it would be a desirable aspect for a water stress indicator to be a good predictor of the water deficit effects on yield. The Photochemical Reflectance Index (PRI) monitored by high spatial resolution multispectral airborne imagery has been proven as a water stress indicator significantly correlated with some orange fruit quality parameters such as total soluble solids (TSS), titratable acidity (TA) and the ratio TSS/TA (Suárez et al., 2010; Stagakis et al., 2012). These authors suggest using this indicator to remotely measure plant water stress and to estimate the internal fruit quality parameters in commercial orchards. The PRI index could be used to schedule harvest based on the estimation of these quality parameters in order to maximize gross revenues in those places that value fruit quality over fruit size. However, in the Mediterranean area, almost the whole citrus production is commercialized as fresh fruit and, in these markets, fruit size is more valued than internal fruit quality being therefore fresh fruit the major yield value determinant. Studies with plum (Intrigliolo et al., 2006; Naor, 2004), peach (Naor, 2000) and almond (Shackel et al., 1997) have reported tight relationships between fruit weight and $\Psi_{\mathrm{s}}$ or $\mathrm{g}_{\mathrm{s}}$. In our study, the relationships between fruit weight and $\Psi_{\mathrm{s}}$ or $\mathrm{g}_{\mathrm{s}}$ were significant although with lower fit than those reported for the crops mentioned above (Table 27). $T_{c}$ and $T_{c}-T_{a}$ obtained from the IRTs were not significantly related with fruit weight. These relationships, however, were highly significant $\left(r^{2}=\right.$ $0.72^{* *}$ ) when crown temperature was obtained from thermal imaging. In fact, $T_{c}$ from thermal images was the water stress indicator that better predicted the effect of the water restrictions applied on fruit weight at 
Discussion

harvest. A good correlation between crown temperature and fruit size in orange trees was also observed by other authors (Suárez et al., 2010) for the cv. 'Navelina' in which $\mathrm{T}_{\mathrm{c}}$ was measured with thermal imagery. However, in Suárez et al. (2010), the correlation observed was lower $\left(r^{2}=0.47^{*}\right)$ than that obtained in this experiment probably due to the low level of stress reached by trees. For our experiment, an increase in $\mathrm{T}_{\mathrm{c}}-\mathrm{T}_{\mathrm{a}}$ of $1{ }^{\circ} \mathrm{C}$ on average for the period of water restrictions resulted in a reduction of $5.3 \mathrm{~g}$ in fruit weight.

The good performance of $T_{c}$ measured by a thermal camera for estimating fruit weight reductions as consequence of plant water stress is probably due to the fact that thermal images allowed the integration of large portions of the tree canopy, obtaining then a reliable determination of the actual whole tree canopy temperature. This is one of the main advantages of thermal imaging that, if combined with tools for automatic imaging analysis and canopy temperature extraction, can be used to remotely determine temperature of large areas. Indeed, the present study is among the first to corroborate that $T_{c}$ measurements allow estimating with sufficient precision the effects of plant water stress on average fruit weight at harvest, which as mentioned before is a critical determinant of the fruit commercial value.

In the past, much effort was done to explore the feasibility of using trunk diameter variations as a potential continuous water stress indicator (Ortuño et al., 2010, Férnandez and Cuevas, 2010). It seems that the effort is now more concentrated with using $\mathrm{T}_{\mathrm{c}}$ to that end. The present results justify this new trend since $T_{c}$ provide for a more direct assessment of plant water 
Discussion

status trough stomatal regulation of transpiration and therefore leaf evaporative cooling. The possibility of using this type of tools will indeed facilitate the more widespread adoptions of RDI techniques, which at least in 'Clementina de Nules' under Mediterranean costal environment have been proven to be useful in commercial orchards for increasing tree water use efficiency (experiment 1). Using canopy temperature measurements related with air ambient temperature will allow growers to better control the actual water stress reached during summer irrigation restrictions thereby avoiding that it could become too severe and negatively affect fruit weight. 
5 Conclusions 
The results obtained from the experiments carried out in this $\mathrm{PhD}$ thesis lead us to conclude that:

- Moderate water restrictions can be applied in commercial 'Clementina de Nules' orchards allowing water savings up to $20 \%$ without any significant reduction neither in yield nor in the economic return. We are now confident to support the more widespread adoption of RDI strategies for 'Clementina de Nules' growers in the region.

- Water savings of up to $19 \%$ in 'Navel Lane Late' can be achieved without significant reductions in yield or in the economic return. However, fruit size can be reduced even with water savings of $12 \%$ so plant water status will need to be frequently monitored to avoid an excessive reduction of fruit weight that could impair significantly the yield value when markets require large fruit weights.

- Even after four or five consecutive seasons under RDI, tree bearing capacity was not impaired in citrus trees. This was probably because water restrictions were applied after the end of June fruit drop and water stress did not modify vegetative and reproductive growth flushes.

- Sap flow measurements allowed detecting plant water stress and quantify the transpiration reduction in deficit irrigated trees (15-20\%), suggesting that potential savings in consumptive tree water use can be less considerable than just the irrigation water saving itself and highlighting the importance of soil water reserves when RDI trials are conducted. 
- Absolute sap flow values obtained by using two gauges per tree underestimated the expected tree transpiration. This underestimation could be due either to a systematic error or to the low number of gauges employed per tree, but increasing the number of gauges used would make the system too expensive. On the other hand, when direct calibration cannot be performed, as in commercial orchards, relative transpiration values should be used instead.

- Relative transpiration correlates well with $\Psi_{\mathrm{s}}$ although with high variations between years and species, which make the use of this relationship more difficult in commercial situations.

- Nocturnal-to-diurnal sap flow ratio is likely to be another possible water status indicator obtained from the sap flow gauges, although more specific research in this aspect would be needed to determine how other environmental or tree endogenous factors might influence this parameter apart from plant water status.

- $\mathrm{T}_{\mathrm{c}}$ variations in response to water stress can be detected with a handoperated thermographic camera. Nevertheless, the use of $\mathrm{T}_{\mathrm{c}}$ measurements to detect plant water stress is more suitable for crops like persimmon that are not highly sensitive to vapour pressure deficit and in which leaf characteristics such as leaf size that determine the aerodynamic resistance, allow higher increases of canopy temperature. In crops like citrus, the reduction in transpiration in well-watered trees as consequence of high VPD values could negatively affect the sensitivity of $\mathrm{T}_{\mathrm{c}}$ as a water stress indicator. 
- In orange trees thermal images of the most exposed leaves to the solar radiation seemed to be more appropriate to detect plant water stress than frontal images.

- For the measurement of $\mathrm{T}_{\mathrm{c}}$, however, the use of methods which include a large amount of leaves in the measurement, as it is the case of thermal imaging, seems to be more appropriate than methods with a few number of leaves measured as with the fixed infrared thermometer sensors.

- $\mathrm{T}_{\mathrm{c}}-\mathrm{T}_{\mathrm{a}}$ and the CWSI did not predict well $\Psi_{\mathrm{s}}$ for a whole season in our experiments.

- The use of $\mathrm{T}_{\mathrm{c}}$ and sap flow measurements as water stress indicators should be used in relative terms using control plants irrigated at potential evapotranspiration as a reference.

- $\mathrm{T}_{\mathrm{c}}$ obtained from thermal imaging is a good predictor of deficit irrigation effects on fruit size. 


\section{References}

Agustí M (2003a) Introducción. In: Citricultura. $2^{\text {nd }}$ edition, Mundi-Prensa, Spain, pp. 19-37.

Agustí M (2003b) Anatomía de los cítricos. In: Citricultura. $2^{\text {nd }}$ edition, Mundi-Prensa, Spain, pp. 65-88.

Agustí M, Martínez-Fuentes A, Mesejo C, Mariano J, Almela V (2003c) El Desarrollo de un Fruto cítrico. In: Cuajado y Desarrollo de los Frutos cítricos. Generalitat Valenciana, Conselleria de Agricultura, Pesca y Alimentación, pp 11.

Allen RG, Pereira LS, Raes D, Smith M (1998) Crop evapotranspiration: Guidelines for computing crop water requirements. In: United Nations FAO, Irrigation and Drainage. Paper 56. FAO, Rome, Italy.

Annandale JG, Stockle CO (1994) Fluctuation of crop evapotranspiration coefficients with weather: a sensitivity analysis. Irrig. Sci. 15:1-7.

Badal E, Buesa I, Guerra D, Bonet L, Ferrer P, Intrigliolo DS (2010) Maximum diurnal trunk shrinkage is a sensitive indicator of plant water stress in Diospyros Kaki (Persimmon trees). Agric. Water Manage. 98:143-147.

Ballester C, Castel J, Sanz F, Yeves A, Intrigliolo DS, Castel JR (2011) Can sap flow probes be used for determining transpiration of Citrus trees under different irrigation regimes? Acta Hort. (ISHS) 922:221-228.

Barrett DJ, Hatton TJ, Ash JE, Ball MC (1995) Evaluation of the heat-pulse velocity technique for measurement of sap flow in rainforest and eucalypt forest species of south-eastern Australia. Plant Cell Environ. 18:463-469. 
Barry GH, Castle WS, Davies FS (2004) Rootstocks and plant water relations affect sugar accumulation of citrus via osmotic adjustment. J. Amer. Soc. Hort. Sci. 129:881-889.

Becker P (1998) Limitation of a compensation heat pulse velocity system at low sap flow: implications for measurements at night and in shaded trees. Tree Physiology 18:177-184.

Becker P, Edwards WRN (1999) Corrected heat capacity of wood for sap flow calculations. Tree Physiology 17:767-768.

Berni JA, Zarco-Tejada P, Suárez L, Fereres E (2009) Thermal and narrowband multispectral remote sensing for vegetation monitoring from an unmanned aerial vehicle. IEEE Trans. Geosci. Remote Sens. 47(3):722-738.

Bevington KB, Castle WS (1985) Annual root growth pattern of young citrus trees in relation to shoot growth, soil temperature and soil water content. J. Amer. Soc. Hort. Sci., 110:840-854.

Castel JR (1997) Evapotranspiration of a drip-irrigated Clementine citrus tree in a weighing lysimeter. Acta Horticulturae, 449 (1):91-98.

Castel JR (2000) Water use of developing citrus canopies in Valencia, Spain. Proc Int. Soc. Citriculture, IX Congr. 2000, 223-226.

Castel JR, Bautista I, Ramos C, Cruz G (1987) Evapotranspiration and irrigation efficiency of mature orchards in Valencia (Spain). Irrigation and Drainage Systems 3:205-217.

Castel JR, Buj A (1989) Response of mature "Salustiana" oranges to high frequency deficit irrigation. Irrig. Sci. 11:121-127. 
Castel JR, Buj A, Ramos C (1989) Comparación del riego por goteo y a manta en naranjos adultos "salustiana". Investigación Agraria: Producción y protección vegetal 4:393-412.

Čermák J, Kučera J, Nadezhdina N (2004) Sap flow measurements with some thermodynamic methods, flow integration within trees and scaling up from sample trees to entire forest stands. Trees 18:529-546.

Chalmers DJ, Burge G, Jerie PH, Mitchell PD (1986) The mechanism of regulation of 'Barlett' pear fruit and vegetative growth by irrigation withholding and deficit irrigation. J. Amer. Soc. Hort. Sci., 111(6):904907.

Chalmers DJ, Mitchell PD, van Heek L (1981) Control of peach tree growth and productivity by regulated water supply, tree density and summer pruning. J Am Soc Hort Sci 106:307-312.

Cohen A, Goell A. (1988) Fruit growth and dry matter accumulation in grapefruit during periods of water withholding and after reirrigation. Aust. J. Plant Physiol. 15, 633-639.

Dalley MJ, Phillips N (2006) Interspecific variation in nighttime transpiration and stomatal conductance in a mixed New England deciduous forest. Tree Physiology 26:411-419.

Day W (1981) Water stress and crop growth. Physiogical processes limiting plant productivity (C.B. Jhonson, ed.) Tutterworths, London, pp. 199-216.

Denmead O, Shaw R (1962) Availability of soil water to plants as affected by soil moisture content and meteorological conditions. Agr. J. 54:385390. 
Domingo R (1994) Respuesta del limonero fino al riego deficitario controlado. Aspectos fisiológicos. Tesis Doctoral, Universidad de Murcia, $232 \mathrm{pp}$.

Doorenbos J, Kassam AH (1986) Yield response to water. FAO Irrigation and Drainage Paper $\mathrm{N}^{\circ} 33$.

Doorenbos J, Pruitt WO (1977) Guidelines for predicting crop water requirements. In: FAO Irrigation and Drainage. Paper $\mathrm{N}^{\circ} 24$, 2nd edition FAO, Rome, Italy, $156 \mathrm{pp}$.

Dragoni D, Lakso AN, Piccioni RM (2005) Transpiration of Apple trees in a humid climate using heat pulse sap flow gauges calibrated with wholecanopy gas Exchange chambers. Agric. Forest Meteorol. 130:85-94.

Dragoni D, Lakso AN, Piccioni RM, Tarara J (2006) Transpiration of grapevines in the humid northeastern United States. Am. J. Enol. Vitic. $57: 4$.

FAOSTAT (2010)

http://faostat3.fao.org/home/index.html\#VISUALIZE_BY_DOMAIN

Fereres E, Soriano MA (2007) Deficit irrigation for reducing agricultural water use. J. Exp. Bot. 58:147-159.

Fernández JE, Palomo MJ, Díaz-Espejo A, Clothier BE, Green SR, Girón,IF, Moreno F (2001) Heat-pulse measurement of sap flow in olives for automating irrigation: tests, root flow and diagnostics of water stress. Agric. Water Manage. 51:99-123.

Fernández JE, Durán PJ, Palomo MJ, Díaz-Espejo A, Chamorro V, Girón IF (2006) Calibration of sap flow estimated by the compensation heat pulse 
method in olive, plum and orange trees: relationships with xylem anatomy. Tree Physiology 26:719-728.

Fernández JE, Green SR, Caspari HW, Díaz-Espejo A. Cuevas MV (2007) The use of sap flow measurements for scheduling irrigation in olive, apple and Asian pear trees and in grapevines. Plant Soil 305:91-104.

Fernández JE, Romero R, Montaño JC, Diaz-Espejo A, Muriel JL, Cuevas MV, Moreno F, Girón IF, Palomo MJ (2008) Design and testing of an automatic irrigation controller for fruit tree orchards, based on sap flow measurements. Aust. J. Agr. Res., 59:589-598.

Fernández JE, Cuevas MV (2010) Irrigation scheduling from stem diameter variations: A review. Agric. Forest Meteorol. 150:135-151.

Fernández JE (2011) www.wgsapflow.com/methods.pdf

Ferreira MI, Katerji N (1992) Is stomatal conductance in a tomato crop controlled by soil or atmosphere? Oecologia 92:104-107.

Fuchs M (1990) Infrared measurement of canopy temperature and detection of plant water stress. Theor. Appl. Climatol. 42:253-261.

García-Petillo M, Castel JR (2007) Water balance and crop coefficient estimation of a citrus orchard in Uruguay. Spanish Journal of Agricultural Research, 5(2):232-243.

García-Tejero I, Durán-Zuazo VH, Muriel-Fernández JL, JiménezBocanegra JA (2011) Linking canopy temperature and trunk diameter fluctuations with other physiological water status tools for water stress management in citrus orchards. Functional Plant Biology 38:106-117.

García-Tejero I, Romero-Vicente R, Jiménez-Bocanegra JA, MartínezGarcía G, Durán-Zuazo, Muriel-Fernández JL (2010) Response of citrus 
trees to deficit irrigation during different phenological periods in relation to yield, fruit quality, and water productivity. Agric. Water Manage. 97:689-699.

Garrido A, Llamas M.R (2009) Water management in Spain: An example of changing paradigms. In Policy and strategic behavior in water resource management. Earthscan, London, 125-144. ISBN 978-1-84407-669-7.

Gates DM (1964) Leaf temperature and transpiration. Agron. J. 56:273-277.

Ginestar C, Castel JR (1996) Response of young 'Clementine' citrus trees to water stress during different phenological periods. J. Hort. Sci. 71(4):551559.

Girona J, Mata M, Goldhamer DA, Johnson RS, DeJong DM (1993) Patterns of soil and tree water status and leaf functioning during regulated deficit irrigation scheduling in peach. J. Amer. Soc. Hort. Sci. 118(5):580-586.

Goldhamer D, Fereres E (2001) Irrigation scheduling protocols using continuously recorded trunk diameter measurements. Irrig. Sci. 20:115125.

Goldhamer D.A, Salinas M (2000) Evaluation of regulated deficit irrigation on mature orange trees grown under high evaporative demand. Proc. Internl. Soc. Citricult. IX Congress 227-231.

González-Altozano P, Castel JR (1999) Regulated deficit irrigation in 'Clementina de Nules' citrus trees. I: Yield and fruit quality effects. J. Hort. Sci. Biotech. 74 (6), 706-713. 
González-Altozano P, Castel JR (2000) Effects of regulated deficit irrigation on 'Clementina de Nules' citrus trees growth, yield and fruit quality. Acta Horticulturae. 537:749-758.

González-Dugo V, Zarco-Tejada P, Berni JAJ, Suárez L, Goldhamer D, Fereres E (2012) Almond tree canopy temperature reveals intra-crown variability that is water stress-dependent. Agric. Forest Meteorol. 15415:156-165.

Grant MO, Tronina L, Jones HG, Chaves M (2007) Exploring thermal imaging variables for the detection of stress responses in grapevine under different irrigation regimes. J. Exp. Bot. 58(4):815-825.

Green SR, Clothier B (1988) Water use of kiwifruit vines and apple trees by the heat-pulse technique. J. Exp. Bot. 39:115-123.

Green SR, Clothier B, Jardine B (2003) Theory and Practical Application of Heat Pulse to Measure Sap Flow. Agron. J. 95:1371-1379.

Grieve AM (1989) Water use efficiency, nutrient uptake and productivity of micro-irrigated citrus. Australian Journal of Experimental Agriculture, 29(1):111-118.

Grismer ME (2000) Long-term evapotranspiration from coastal avocadocitrus orchard. Journal of Irrigation and Drainage Engineering 126(1):1-7.

Hatton TJ, Catchpole EA, Vertessy RA (1990) Integration of sap flow velocity to estimate plant water use. Tree Physiology 6:201-209.

Hilgeman RH (1977) Response of citrus trees to water stress in Arizona. Proceedings of the International Society of Citriculture (Orlando), 1:70-74. 
Hockema BR, Etxeberria E (2001) Metabolic contributors to droughtenhanced accumulation of sugars and acids in oranges. J. Amer. Soc. Hort. Sci. 126:599-605.

Hoffman GJ, Oster JD, Alves WJ (1982) Evapotranspiration of mature orange trees under drip irrigation in an arid climate. Transactions of the ASAE (American Society of Agricultural Engineers), 25(4): 992-996.

Hsiao TC (1973) Plant responses to water stress. Annu. Rev. Plant Physiology 24:519-570.

Hsiao TC (1993) Growth and productivity of crops in relation to water stress. Acta Horticulturae, 335:137-148.

Hsiao TC, Acevedo E, Fereres E, Henderson DW (1976) Water stress, growth and osmotic adjustment. Phil. Trans. R. Soc. London, Ser. B., 273:471-500.

Huber B (1932) Beobachtung und Messung pflanzlicher Saftströme. Ber. Dt. Bot. Ges. 50:89-109.

Huber B, Schmidt E (1937) Eine Kompensationsmethode zur thermoelektrischen messung langsamer saftströme. Ber. Dtsch. Bot. Ges. 55:514-529.

Hutton RJ, Landsberg JJ, Sutton G (2007) Timing irrigation to suit citrus phenology: a means of reducing water use without compromising fruit yield and quality? Australian J. Exp. Ag. 47:71-80.

Intrigliolo DS, Castel JR (2006) Performance of various water stress indicators for prediction of fruit size response to deficit irrigation in plum. Agric. Water Manage. 83:173-180. 
Idso SB, Jackson RD, Pinter PJ, Reginato RJ, Hatfield JL (1981) Normalizing the stress-degree-day parameter for environmental variability. Agric. Forest Meteorol. 24:45-55.

Jackson RD (1982) Canopy temperature and crop water stress. In: Hillel D, ed. Advances in Irrigation, Vol. 1. Academic Press, 43-85.

Jiménez-Bello MA, Ballester C, Castel JR, Intrigliolo DS (2011) Development and validation of an automatic thermal imaging process for assessing plant water status. Agric. Water Manage. 98:1497-1504.

Jones HG (1983) Estimation of an effective soil water potential at the root surface of transpiring plants. Plant Cell Environ. 6:671-674.

Jones HG (1985) Physiological and environmental control of evaporation from plants and implications for plant water status. Les Besoins en Eau des Cultures. Conférence Internationale. Paris, 1984. CIID INRA: 23-33.

Jones HG (1999) Use of infrared thermometry for estimation of stomatal conductance as a possible aid to irrigation scheduling. Agric. Forest Meteorol. 95:139-149.

Jones HG (2004) Irrigation scheduling: advantages and pitfalls of plantbased methods. J. Exp. Bot. 55:2427-2436.

Jones HG, Serraj R, Loveys BR, Xiong L, Wheaton A, Price AH (2009) Thermal infrared imaging of crop canopies for the remote diagnosis and quantification of plant responses to water stress in the field. Funct. Plant Biol., 36:978-989.

Jones HG, Stoll M, Santos T, de Sousa C, Chaves MM, Grant OM (2002) Use of infrared thermography for monitoring stomatal closure in the field: application to grapevine. J. Exp. Bot. 53:2249-2260. 
Kramer PJ, Boyer JS (1995) Water relations of plants and soils. Academic Press, New York.

Kriedemann PE, Barrs MD (1981) Citrus orchards. In: Water deficit and plant growth (T.T. Kozlowski. Ed.) Academia Press, New York. 6:325417.

Landsberg JJ, Jones HG (1981) Apple orchards. Water deficits and plant growth (T.T. Kolowski ed.), Vol.6. Academic Press, London. p. 419-469.

Levy Y, Bielorai H, Shalhevet J (1978) Long-term effects of different irrigation regimes on grapefruit tree development and yield. J. Amer. Soc. Hort. Sci 103:680-683.

López-Bernal A, Alcántara E, Testi L, Villalobos FJ (2010) Spatial sap flow and xylem anatomical characteristics in olive trees under different irrigation regimes. Tree Physiology 30:1536-1544.

MARM (2010)

http://www20.gencat.cat/docs/DAR/DE_Departament/DEO2_Estadistiqu es_observatoris/00_Altres_publicacions/Fitxers_estatics/Anuari_Estadisti ca_2010.pdf

Marshall DC (1958) Measurement of sap flow in conifers by heat transport. Plant Physiology 33:385-396.

Merlot S, Mustilli AC, Genty B, North H, Lefebvre V, Sotta B, Vavasseur A, Giraudat J (2002) Use of infrared thermal imaging to isolate Arabidopsis mutants defective in stomatal regulation. Plant J. 30:601-609. Mitchel PD, Chalmers DJ (1982) The effect of reduced water supply on peach tree growth and yields. J. Amer. Soc. Hort. Sci. 107:853-856. 
Mitchel PD, van den Ende B, Jerie PH, Chalmers DJ (1989) Responses of 'Barlett' pear to withholding irrigation, regulated deficit irrigation, and tree spacing. J. Amer. Soc. Hort. Sci. 114:15-19.

Molden D (2007) Water for Food, Water for Life: A Comprehensive Assessment of Water Management in Agriculture. Earthscan, London.

Möller M, Alchanatis V, Cohen Y, Meron M, Tsipris J, Ostrovsky V (2007) Use of thermal and visible imagery for estimating crop water status of irrigated grapevine. J. Exp. Bot. 58:827-838.

Monteith JL, Unsworth MH (2008) Principles of Environmental Physics. Elsevier/Academic Press, p.440.

Moriana A, Villalobos MJ, Fereres E (2002) Stomatal and photosynthetic responses of olive (Olea Europea L.) leaves to water deficit. Plant Cell Environ. 25:395-405.

Myers BJ (1988) Water stress integral. A link between short term stress and long term growth. Tree Physiology 4:315-323.

Nadezhdina N, Nadezhdin V, Ferreira MI, Pitacco A (2007) Variability with xylem depth in sap flow in trunks and branches of mature olive trees. Tree Physiology 27:105-113.

Naor A (2000) Midday stem water potential as a plant water stress indicator for irrigation scheduling in fruit trees. Acta Hort. (ISHS) 537:447-454.

Naor A (2004) The interaction of soil- and stem-water potential with crop level, fruit size and stomatal conductance of field-grown 'Black-Amber' Japanese plum. J. Hortic. Sci. Biotech. 79:273-280.

Naor A (2006) Irrigation scheduling and evaluation of tree water status in deciduous orchards. Hort. Rev. 32:111-116. 
Navarro JM (2008) Effects of differing deficit irrigation treatments on fruit quality of Citrus reticulata Blanco. Proc. Int. Soc. Citric. 1:701-706.

Nobel PS (2009) Physiochemical and environmental plant physiology. Elsevier/Academic Press, p.337.

Oguntunde PG, Van de Giesen N, Savenige HHG (2007) Measurement and modelling of transpiration of a rain-fed citrus orchard under subhumid tropical conditions. Agric. Water Manage. 87:200-208.

Ortuño MF, Alarcón JJ, Nicolás E, Torrecillas A (2007) Water status indicators of lemon trees in response to flooding and recovery. Biologia Plantarum 51(2):292-296.

Ortuño MF, Conejero W, Moreno F, Moriana A, Intrigliolo DS, Biel C, Mellisho CD, Pérez-Pastor A, Domingo R, Ruiz-Sánchez MC, Casadesus J, Bonany J, Torrecillas A 2010. Could trunk diameter sensors be used in woody crops for irrigation scheduling? A review of current knowledge and future perspectives. Agric. Water Manage., 97, 1-11.

Ortuño MF, García-Orellana Y, Conejero W, Ruíz-Sánchez MC, Alarcón JJ, Torrecillas A 2006. Stem and leaf water potentials, gas exchange, sap flow and trunk diameter fluctuations for detecting water stress in lemon trees. Trees 20, 1-8.

Pérez-Pérez JG, Robles JM, Botía P (2009) Influence of deficit irrigation in phase III of fruit growth on fruit quality in 'Lane Late' sweet orange. Agric. Water Manage. 96:969-974.

Pérez-Pérez JG, García J, Robles JM, Botía P (2010) Economic analysis of navel orange cv. 'Lane Late' grown on two different drought-tolerant 
rootstocks under deficit irrigation in South-eastern Spain. Agric. Water Manage. 97:157-164.

Romero P, Navarro JM, Pérez-Pérez JG, García-Sánchez F, Gómez-Gómez A, Porras I, Martínez V, Botía P (2006) Deficit irrigation and rootstock: their effects on water relations, vegetative development, yield, fruit quality and mineral nutrition of Clemenules mandarin. Tree Physiol 26:1537-1548.

Ruiz Sánchez MC, Domingo R, Castel JR (2010) Deficit irrigation in fruit trees and vines in Spain: A review. Spanish Journal of Agricultural Research 8(S2), S5-S20.

SAS Institute (1994) SAS/STAT User's Guide. SAS Inst. Inc., Cary, NC, USA.

Shackel KA, Ahmadi H, Biasi W, Buchner R, Goldhamer D, Gurusinghe S, Hasey J, Kester D, Krueger B, Lampinen B, McGourty G, Micke W, Mitcham E, Olson B, Pelletrau K, Philips H, Ramos D, Schwankl L, Sibbert S, Snyder R, Southwick S, Stevenson M, Thorpe M, Weinbaum S, Yeager J (1997) Plant water status as an index of irrigation need in deciduous fruit trees. Hort Technology 7:23-29.

Scherrer D, Bader MK, Körner C (2011) Drought-sensitivity ranking of deciduous tree species based on thermal imaging of forest canopies. Agric. Forest Meteorol. 151:1632-1640.

Sepulcre-Cantó G, Zarco-Tejada PJ, Jiménez-Muñoz JC, Sobrino JA, de Miguel E, Villalobos FJ (2006) Detection of water stress in an olive orchard with thermal remote sensing imagery. Agric. Forest Meteorol. 136:31-44. 
Sepulcre-Cantó G, Zarco-Tejada PJ, Sobrin J.A, Berni JA, Jiménez-Muñoz JC, Gastellu-Etchegorry JP (2009) Discriminating irrigated and rainfed olive orchard with thermal ASTER imagery and DART 3D simulation. Agric. Forest Meteorol. 149:962-975.

Smith DM, Allen SJ (1996) Measurements of sap flow in plant stems. J. Exp. Bot. 47:1833-1844.

Stagakis S, González-Dugo V, Cid P, Guillén-Climent ML, Zarco-Tejada PJ (2012) Monitoring water stress and fruit quality in an orange orchard under regulated deficit irrigation using narrow-band structural and physiological remote sensing indices. ISPRS J. Photogramm., 71:47-61. Suárez L, Zarco-Tejada PJ, González-Dugo V, Berni JAJ, Sagardoy R, Morales F, Fereres E (2010) Detecting water stress effects on fruit quality in orchards with time-series PRI airborne imagery. Remote Sensing of Environment, 114:286-298.

Swanson, R.H., Whitfield, D.W.A., 1981. A numerical-analysis of heat pulse velocity theory and practice. J. Exp. Bot. 32, 221-239.

Swanson RH, Whitfield DWA (1981) A numerical-analysis of heat pulse velocity theory and practice. J. Exp. Bot. 32:221-239.

Swingle WT (1967) Botany of citrus and its wild relatives. In: The Citrus Industry, vol. 1. Univ. Calif. Div. Agric. Sci., California, EE.UU.

Syvertsen JP (1985) Integration of water stress in fruit trees. HortScience, 20:1039-1043.

Syvertsen P, Lloyd J (1994) Citrus. In: Handbook of environmental physiology. CRC Press, Boca Ratón, USA pp. 65-99. 
Testi L, Goldhamer DA, Iniesta F, Salinas M (2008) Crop water stress index is a sensitive water stress indicator in pistachio trees. Irrig. Sci. 26:395405.

Testi L, Villalobos FJ (2009) New approach for measuring low sap velocities in trees. Agric. Forest Meteorol. 149:730-734.

Turner NC (1981) Techniques and experimental approaches for the measurement of plant water status. Plant and Soil 58:339-366.

Valancogne C, Dayau S, Ferreira Gama MI, Ameglio T, Archer P, Daudet FA, Cohen, M (1997) Relations between relative transpiration and predawn leaf water potential in different fruit tree species Acta Hort. (ISHS) 449:423-430.

Van Bavel CHM, Newman JE, Hilgeman RH (1967) Climate and estimated water use by an orange orchard. Agric. Forest Meteorol. 4:27-37.

Van Den Honert TM (1948) Water transport as a catenary process. Discuss. Faraday Soc. 33:146-153.

Villalobos FJ, Testi L, Moreno-Perez MF (2009) Evaporation and canopy conductance of citrus orchards. Agric. Water Manage. 96:565-573.

Wang D, Gartung J (2010) Infrared canopy temperature of early-ripening peach trees under postharvest deficit irrigation. Agric. Water Manage. 97:1787-1794.

Wardowski WM, Hall DJ, Gierson W (2006) Fresh citrus fruits $\left(2^{\text {nd }}\right.$ Edition). Florida Science Source, Inc. Florida, USA.

Yakushiji H, Nonami H, Fukuyama T, Ono S, Takagi N, Hashimoto Y (1996) Sugar accumulation enhanced by osmoregulation in Satsuma mandarin fruit. J. Amer. Soc. Hort. Sci. 121:466-472. 
Zarco-Tejada P, Gonzalez-Dugo V, Berni JAJ (2012) Fluorescence, temperature and narrow-band indices acquired from a UAV platform for water stress detection using a micro-hyperspectral imager and a thermal camera. Remote Sensing of Environment, 117:322-337. 